\title{
The vegetation of the Balsam Mountains of southwest Virginia: A phytosociological study
}

Richard D. Rheinhardt

College of William \& Mary - Arts \& Sciences

Follow this and additional works at: https://scholarworks.wm.edu/etd

Part of the Botany Commons

\section{Recommended Citation}

Rheinhardt, Richard D., "The vegetation of the Balsam Mountains of southwest Virginia: A phytosociological study" (1981). Dissertations, Theses, and Masters Projects. Paper 1539625126.

https://dx.doi.org/doi:10.21220/s2-4ctb-nk74

This Thesis is brought to you for free and open access by the Theses, Dissertations, \& Master Projects at W\&M ScholarWorks. It has been accepted for inclusion in Dissertations, Theses, and Masters Projects by an authorized administrator of W\&M ScholarWorks. For more information, please contact scholarworks@wm.edu. 
THE VEGETATION OF THE BALSAM MOUNTAINS OF SOUTHWEST VIRGINIA: A PHYTOSOCIOLOGICAL STUDY

\author{
A thesis \\ Presented to \\ The Faculty of the Department of Biology \\ The College of William and Mary in Virginia
}

\author{
In partial fulfillment \\ of the Requirements for the Degree of \\ Master of Arts
}

by

Richard D. Rheinhardt

1981 
ERRATA

pg. 23 Midpoint value of $25-50$ is 37.5 .

pg. 24 Midpoint value of $5-25$ is 15.0 .

pg. 33 Negative correlation of magnesium for y-axis should be under .05 leve1.

pg. 53 Size class 2 of Fagus grandifolia does not show a significant correlation with potassium (K+).

pg. 61 Last line of first paragraph should be potassium levels, not phos phorus levels.

pg. $68,76,82$ Arisaema triphyllum is correct spelling, rather than A. trifolium.

pg. 70 Total basal area for stands: $28=22 \mathrm{~m} / \mathrm{ha}, \quad 7=34 \mathrm{~m} / \mathrm{ha}, \quad 32=22$ $\mathrm{m} / \mathrm{ha}, 43=28 \mathrm{~m} / \mathrm{ha}, \mathrm{T}=38 \mathrm{~m} / \mathrm{ha}, 50=24 \mathrm{~m} / \mathrm{ha}, \mathrm{P}=31 \mathrm{~m} / \mathrm{ha}, 35=33$

$\mathrm{m} / \mathrm{ha}, 37=26 \mathrm{~m} / \mathrm{ha}, \mathrm{K}=32 \mathrm{~m} / \mathrm{ha}, \mathrm{D}=38 \mathrm{~m} / \mathrm{ha}, 33=29 \mathrm{~m} / \mathrm{ha}, \quad 8=30$

$\mathrm{m} / \mathrm{ha}, 39=38 \mathrm{~m} / \mathrm{ha}, \mathrm{Q}=31 \mathrm{~m} / \mathrm{ha}, \mathrm{B}=35 \mathrm{~m} / \mathrm{ha}, 14=32 \mathrm{~m} / \mathrm{ha}, 38=25$

$\mathrm{m} / \mathrm{ha}, 16=25 \mathrm{~m} / \mathrm{ha}, 44=32 \mathrm{~m} / \mathrm{ha}, \mathrm{H}=39 \mathrm{~m} / \mathrm{ha}, 27=28 \mathrm{~m} / \mathrm{ha}$.

pg. 74 For stand A, basal area $=34 \mathrm{~m} / \mathrm{ha}$; Hydrophyllum canadense occurs in stand A with I.V. $=6.4$.

pg. 76 Total basal area for stands:4l=37 m/ha, $\mathrm{z}=36 \mathrm{~m} / \mathrm{ha}, \quad 40=36$ $\mathrm{m} / \mathrm{ha}, \mathrm{S}=35 \mathrm{~m} / \mathrm{ha}, 46=25 \mathrm{~m} / \mathrm{ha}$; Uvularia is correct spelling for genus.

pg. 101 The Cumberland Plateau is a part of the lixed Mesophytic Forest Region also.

Pg. 135 Species diversity for stands (st) based on basal area values: st $31=.71$, st $41=1.44$, stR=2.06, st $Y=.67$; Pg. 135 For species diversity based on importance values: $s t F=1.05$, st $G=1.20$. 
APPROVAL SHEET

This thesis is submitted in partial fulfillment of the requirements for the degree of Master of Arts

Richard D. Reinhardt Author

Approved, November 1981
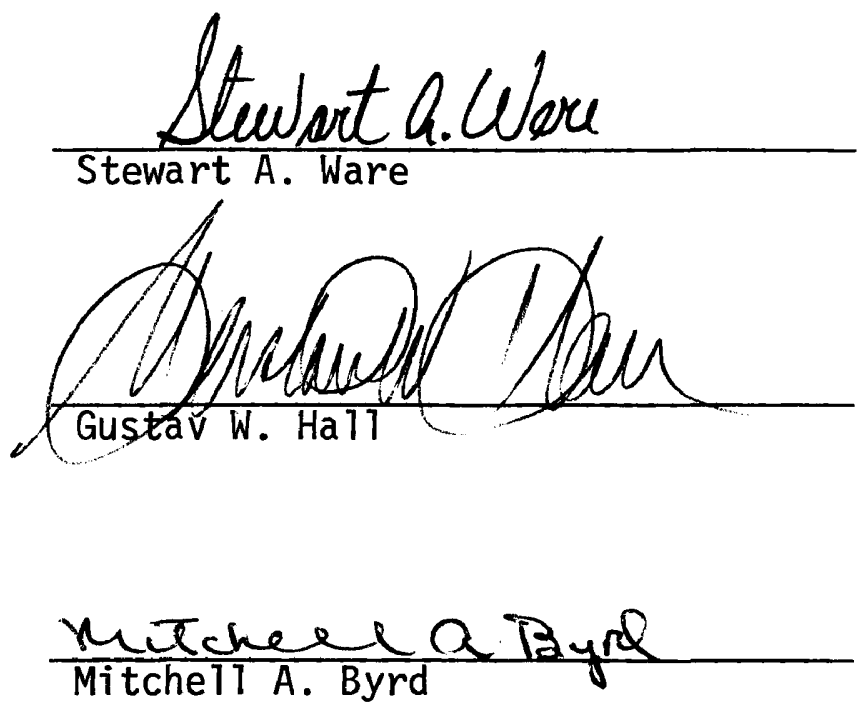

i 


\section{TABLE OF CONTENTS}

Page

ACKNOWLEDGMENTS $\ldots \ldots \ldots \ldots \ldots \ldots \ldots \ldots \ldots \ldots \ldots \ldots \ldots \ldots \ldots \ldots \ldots \ldots \ldots \ldots$

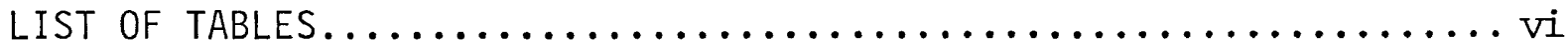

LIST OF FIGURES....................................

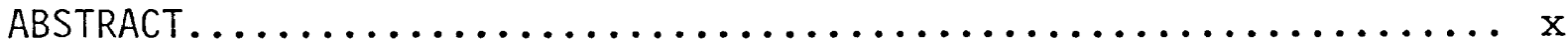

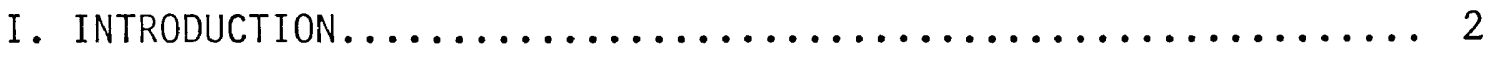

II. THE STUBY ARER............................... 4

Physiography........................... 4

Precipitation............................. 14

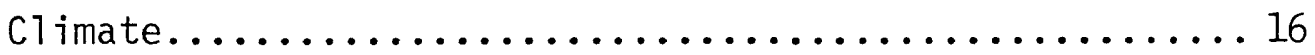

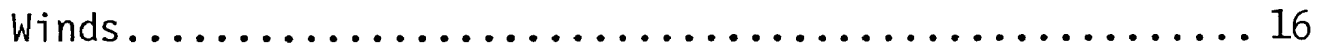

Geology.............................. 16

III. MATERIALS AND METHODS $\ldots \ldots \ldots \ldots \ldots \ldots \ldots \ldots \ldots \ldots \ldots \ldots \ldots \ldots$

Sampling procedures.......................... 21

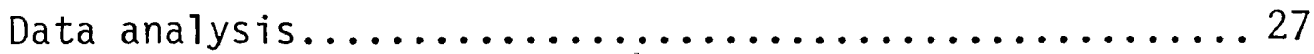

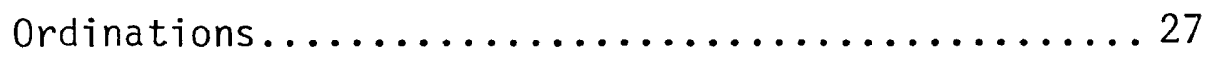

Diversity indices........................ 29

Correlation analysis..................... 30

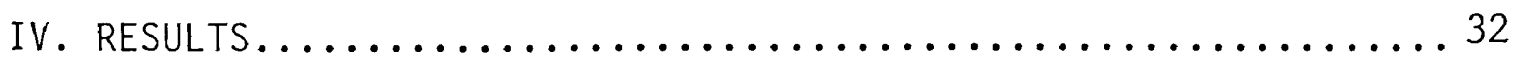

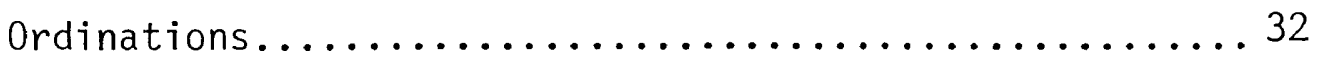

Correlation anaiysis....................... 51

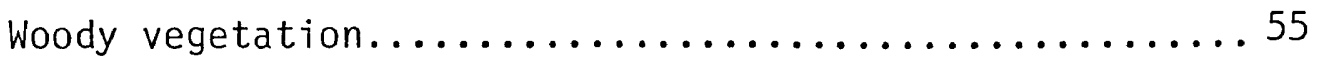

Spruce-fir communities................. 57

spruce communities.....................61 
Yellow birch communities............... 64

Northern hardwoods communities...........66 67

High elevation mixed mesophytic communities.... 72

Northern red oak communities............ 75

Mesophytic-oak communities............. 79

Lower elevation communities............. 81

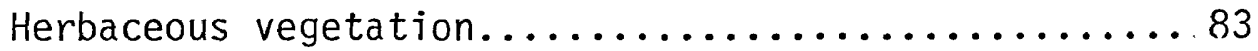

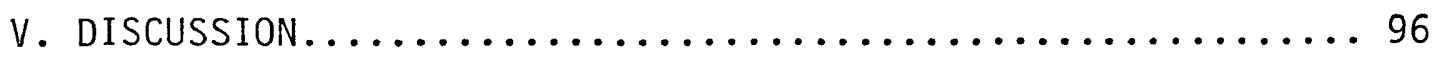

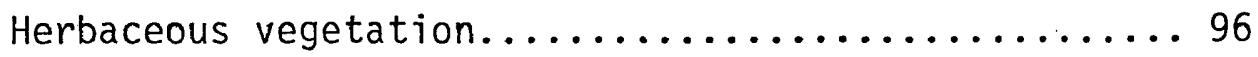

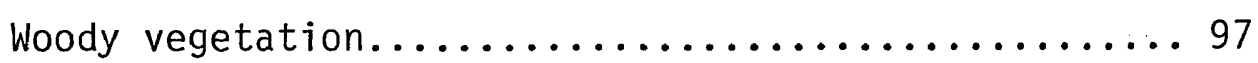

VI. APPENDIX A----Vegetation data..................... 104

VII. APPENDIX B-.--Correlation data..........................

VIII. LITERATURE CITED.......................... 144 


\section{ACKNOWLEDGMENTS}

I would like to express my appreciation to the members of my graduate committee, to Dr. G. W. Hall and to Dr. M. A. Byrd, who carefully reviewed this manuscript, and especially to my committee chairman, Dr. Stewart A. Ware, whose guidance and enthusiasm throughout this investigation have made this study an invaluably rewarding experience.

I would also like to extend my appreciation to Ms. Liz Hawk of the U.S. Forest Service for providing essential preliminary information concerning the study area and to Mr. Kirby Brock, Mount Rogers' district ranger, for permitting the collection of soil samples from the protected areas. Dr. Philip Shelton of Clinch Valley College graciously shared his knowledge of the summit vegetation with me and provided recently acquired temperature and rainfall data from Mount Rogers' peak. Dr. Donna E. Ware, curator of the William and Mary herbareum, assisted in the identification of some herbaceous specimens collected from outside the protected areas. David Reed's and Mark Blanks' help in developing a computer program to accommodate the reams of data which were collected is also greatly appeciated. Special appreciation is also extended to Margaret Lampman, whose help in typing this manuscript has been invaluable. Finally, my sincerest thanks goes to my wife, Lillian, whose constructive criticisms of my writing, encouragement during times of frustration, and exhibition of patience and understanding throughout this degree program has enabled me to reach my goa 1. 


\section{LIST OF TABLES}

Table

Page

1. Stem density categories $\ldots \ldots \ldots \ldots \ldots \ldots \ldots \ldots \ldots \ldots \ldots . \ldots \ldots$

2. Herbaceous coverage classifications................. 24

3. Pebble abundance categories..................... 26

4. Significant correlations between environmental variables... 52

5. Significant correlations between major woody species and environmental variables....................... 53

6. Significant correlations among major woody species....... 54

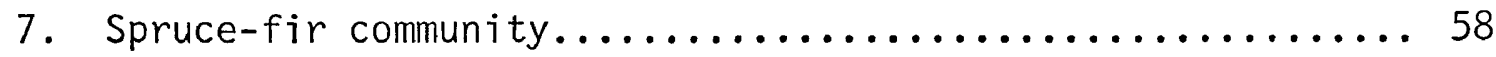

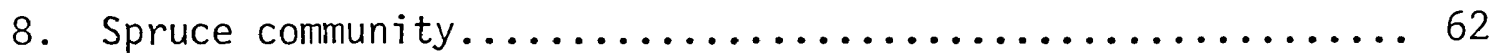

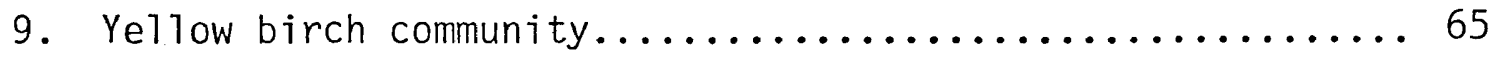

10. Northern hardwoods community (Dwarf orchard subtype)...... 68

11. Northern hardwoods community (Beech-maple subtype) ....... 70

12. High elevation mixed mesophytic community............. 74

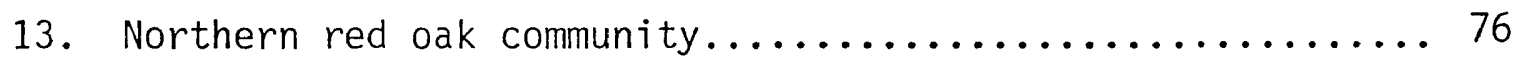

14. Mesophytic-oak community........................ 80

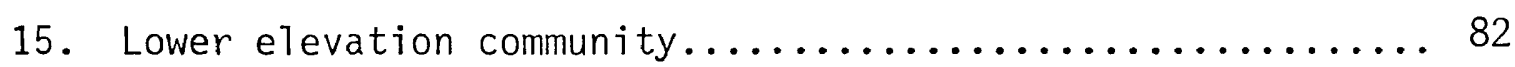

16. Significant correlations between major herbaceous species and environmental variables, and among herbaceous species............................. 91

17. Vascular flora of the Balsam Mountains.................. 106

18. Importance, dominance, and density data for canopy species, by stand............................... 111

19. Relative density data for saplings, larger seedlings, and small seedlings, by stand................. 117 
Table

20. Herbaceous coverage, frequency, and maximum coverage

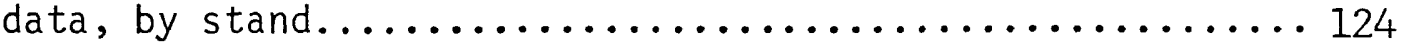

21. Ordination axis values for listed and sampled

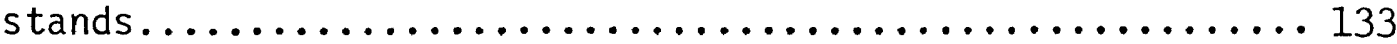

22. Environmental measurements from listed and sampled stands................................ 134

23. Diversity indices, by stand.................... 135

24. Significant correlations between canopy species and environmental variables........................ 137

25. Significant correlations among canopy species........... 141

26. Significant correlations between the 25 most common herbaceous species and environmental variables.......... 142

27. Significant correlations among the 25 most common herbaceous species............................. 143 


\section{LIST OF FIGURES}

Figure

1. Location of the study area with respect to southwest Virginia................................. 5

2. Location of the study area with respect to the Mount Rogers National Recreation Area................. 6

3. Lost Mountain and Beech Mountain study sites............. 7

4. Whitetop Mountain and Elk Garden Ridge study sites........ 8

5. Whitetop Mountain and Bluff Mountain study sites......... 9

6. Mount Rogers and Lewis Fork study sites............... 10

7. Mount Rogers, Elk Ridge, Lewis Fork, and Iron Mountain study sites............................ 11

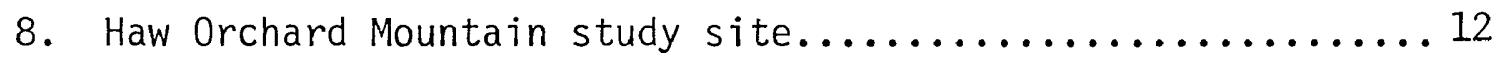

9. Pine Mountain and Mi11 Creek study sites............... 13

10. Precipitation data for Whitetop Mountain.............. 15

11. Temperature data for Whitetop Mountain.............. 17

12. Wind velocity data for Whitetop Mountain.............. 18

13. Geologic cross-section through the Balsam Mountains........20

14. A polar ordination of listed and sampled stands derived from woody species importance values............. 33

15. A polar ordination of sampled and listed stands, $X$ and $Y$ axes only, derived from relative dominance values of

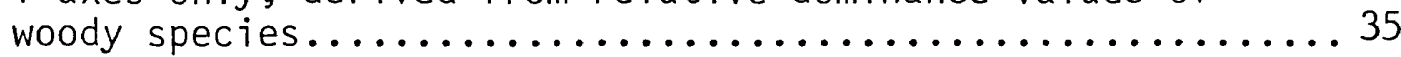

16. A polar ordination of sampled stands derived from woody species importance values........................ 36

17. A polar ordination of sampled stands, $X$ and $Y$ axes only, derived from woody species importance values............. 38

18. Relative dominance values of Abies fraseri and Picea rubens with respect to stand positions on the polar

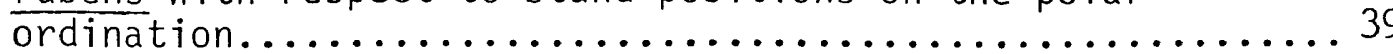

19. Relative dominance values of Betula lutea with respect to stand positions on the polar ordination. 
Figure

20. Relative dominance values of Fagus grandifolia with respect to stand positions on the polar ordination..........

21. Relative dominance values of Acer saccharum with respect to stand positions on the polar ordination..........

22. Relative dominance values of Tilia heterophylla with respect to stand positions on the polar

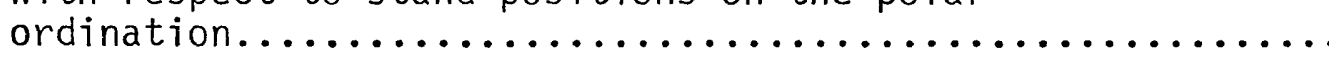

23. Relative dominance values of Quercus rubra with respect to

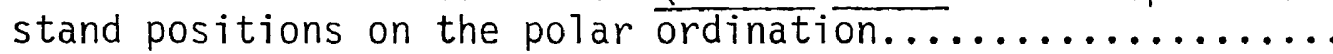

24. A polar ordination of sampled stands derived from

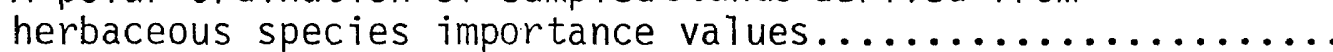

25. A polar ordination of sampled stands, $Y$ and $Z$ axes only, derived from herbaceous species importance

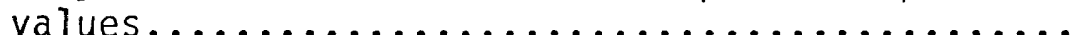

26. Importance values of Maianthemum canadense with respect to stand positions on the porar ordination..........

27. Importance values of 0xal is acetosella and Dryopteris intermedia with respect to stand positions on the

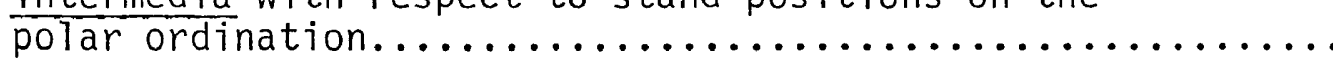

28. Importance values of Eupatorium rugosum with respect

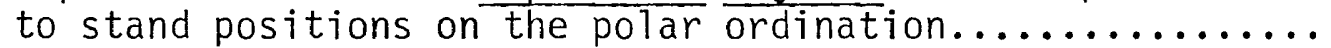

29. Importance values of Rubus canadensis with respect to

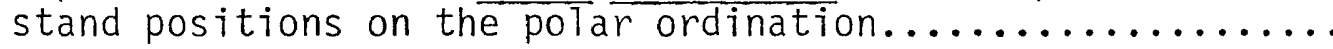


A quantitative phytosociological survey was made of the herbaceous and woody vegetation of the Balsam Mountains of southwest Virginia. Sixty-nine stands were sampled (21 intensively) between 950 and $1747 \mathrm{~m}$ in elevation using the Bitterlich plotless method for canopy vegetation, density measurements for understory vegetation, and percent coverage for herbaceous species. Stands were positioned along a 3-axes vegetational mosaic using the Bray-Curtis ordination technique. Correlation analyses were performed to test for significant relationships between community composition, species abundances, and several environmental parameters.

Most stands were found to be more mesophytic in composition than forests of similar elevations and exposures elsewhere in the southern Blue Ridge Physiographic Province. One fairly extensive community-type of open slopes resembles the mesophytic cove forests of the Great Smokies; it differs only in that it occurs at higher elevations and lacks the lower elevation constituents normally associated with mixed mesophytic forests. Possible explanations for the development of this forest-type are presented.

Woody species tended to correlate predictably with most environmental parameters, particulaily with elevation, moisture, and $\mathrm{pH}$, but a few unanticipated correlations were found. Significant negative correlations were discovered between Picea rubens and manganese and potassium levels, while Quercus rubra correlated negatively with manganese. Positive correlations were found between Abies fraseri and nitrate nitrogen, zinc, and soluble salt concentrations, between Fagus grandifolia and the abundance of pebbles, and between both Tilia heterophylla and Eraxinus americana and levels of calcium and magnesium.

Woody vegetation was divided into eight recurring community-types: spruce, spruce-fir, northern hardwoods, yellow birch, mixed mesophytic, mesophytic-oak, northern red oak, and forests of the mostly disturbed lower elevations.

Herbaceous vegetation was not so easily categorized and did not seem to relate in any predictable manner with the composition of the canopy vegetation, but did seem to significantly relate to elevation and its associated parameters. 
THE VEGETATION OF THE BALSAM MOUNTAINS OF SOUTHWEST VIRGINIA: A PHYTOSOCIOLOGICAL STUDY 


\section{INTRODUCTION}

The Balsam Mountains, a part of the southern Blue Ridge Physiographic Province, are vegetationally unique for Virginia. They contain the Commonwealth's only extensive northern hardwoods and spruce-fir forests, for these mountains consist of the tallest and most massive peaks in Virginia: Mount Rogers (1747m) and Whitetop (1682 m).

Although Shields, in an unpublished dissertation, quantitatively described the boreal forests on the summit of Mount Rogers, he never collected data on the hardwoods of the lower elevations. He was primarily concerned with the summit area because it is dominated by the northernmost natural stand of Abies fraseri (Fraser fir), a species endemic to the southern BTue Ridge Province. Furthermore, he did not sample the vegetation of Whitetop Mountain, whose peak is only $6 \mathrm{~km}$ southwest of Mount Rogers. Although Whitetop's summit is only $65 \mathrm{~m}$ lower in elevation and is therefore climatically suitable for the support of similar vegetation, Fraser fir does not occur there; Picea rubens (red spruce) dominates the highest elevations of Whitetop.

Most phyosociological investigations of the southern Blue Ridge Province have focused on the vegetation of the mountains to the south of Virginia, in areas such as Roan Mountain (Brown, 1941), the Black Mountains (Harshberger, 1911; Davis, 1935; Braun, 1950), the Nantahala Mountains (Oosting, 1941; Braun, 1950), and especially, the Great Smoky Mountains (Cain, 1935; Braun, 1950; and Whittaker, 1956). Hence, it appears that no thorough phytosociological investigations have been 
performed on the forests of the Balsam Mountains. Even Braun's (1950) descriptions of eastern North American forests neglect to mention the vegetation of these mountains.

The purpose of this study, undertaken from May through September of 1980, was to quantitatively describe the diverse vegetation of the Balsam Mountain area, including the forest-types omitted by Shields' earlier study, to compare these forests with other high elevation forests of the southern Blue Ridge Physiographic Province, and to determine whether certain environmental parameters could be significantly correlated with community structure, species distribution patterns, and diversity indices. 


\section{THE STUDY AREA}

\section{Physiography}

The Balsam Mountains of Virginia are within the Mount Rogers $\mathrm{Na}-$ tional Recreation Area of Jefferson National Forest. The study area, situated in Grayson, Smyth, and Washington counties, is located approximately $10 \mathrm{~km}$ northeast of the common border of North Carolina, Tennessee, and Virginia (Figs. 1\&2). Study sites can be located on the USGS quadrangle maps of Grassy Creek, Grayson, Konnarock, Troutdale, and Whitetop Mountain (Figs. 3-9). The forests in this area are all above $950 \mathrm{~m}$ in elevation with most relatively undisturbed stands occurring in the $1200-$ $1750 \mathrm{~m}$ range.

Much of the study area is forested with mature stands of second growth timber; only the boreal forests on the summits and high north slopes of Whitetop and Mount Rogers are believed to be virgin. These forests and the crest region extending to the northeast from Mount Rogers along Pine Mountain are protected by the U.S. Forest Service (Whitfield, 1978). In addition, the spruce forest on whitetop, the proposed Little Wilson Creek and Lewis Fork Wilderness areas, and much of the 1 and contained within Grayson Highlands State Park are also currently under protective stewardship. Altogether, approximately 16,000 ha or $75 \%$ of the study area is present7y protected. In order to evaluated natural conditions affecting forest ecology, the study was concentrated in mature, undisturbed forests, particularly those within the protected areas. 


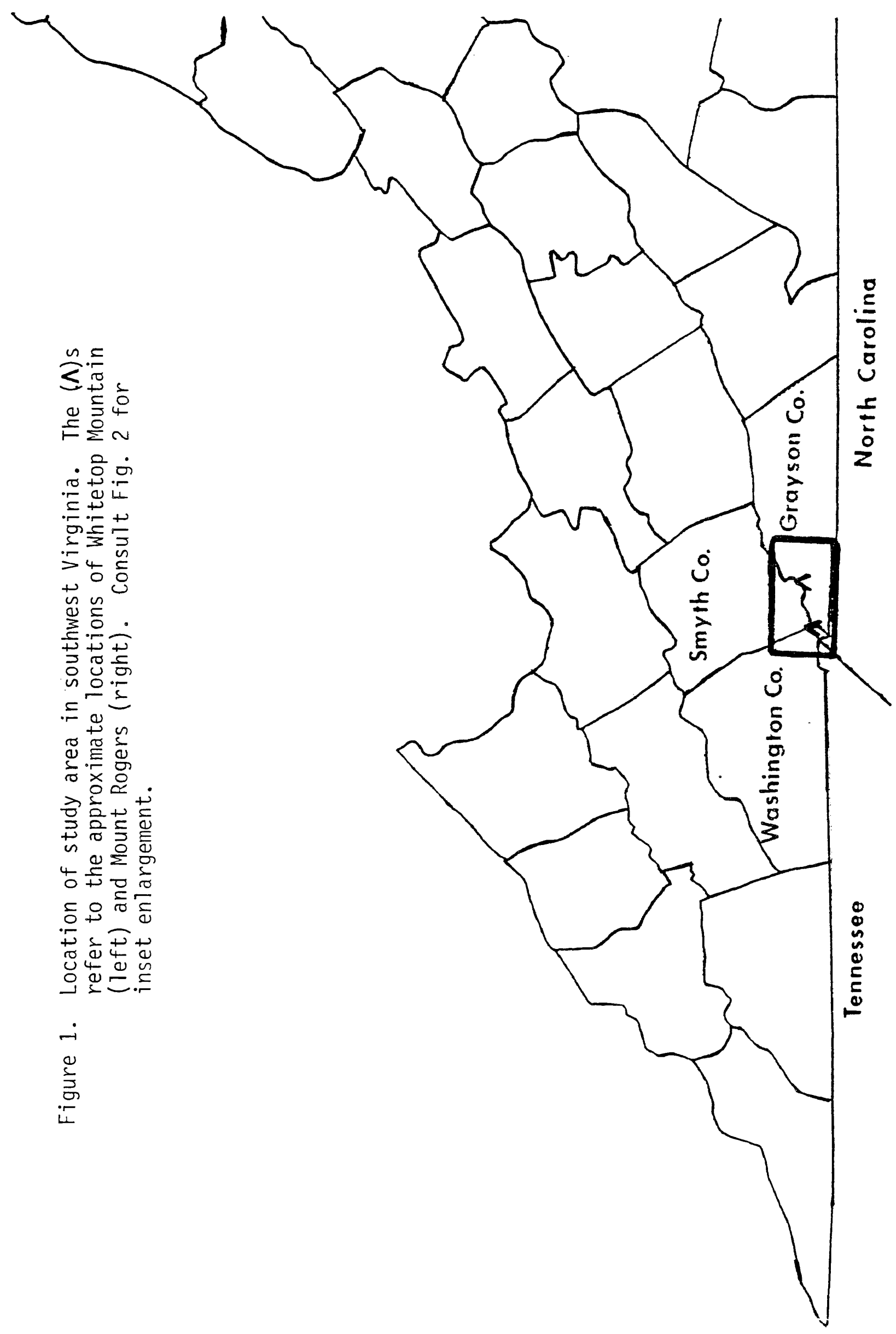




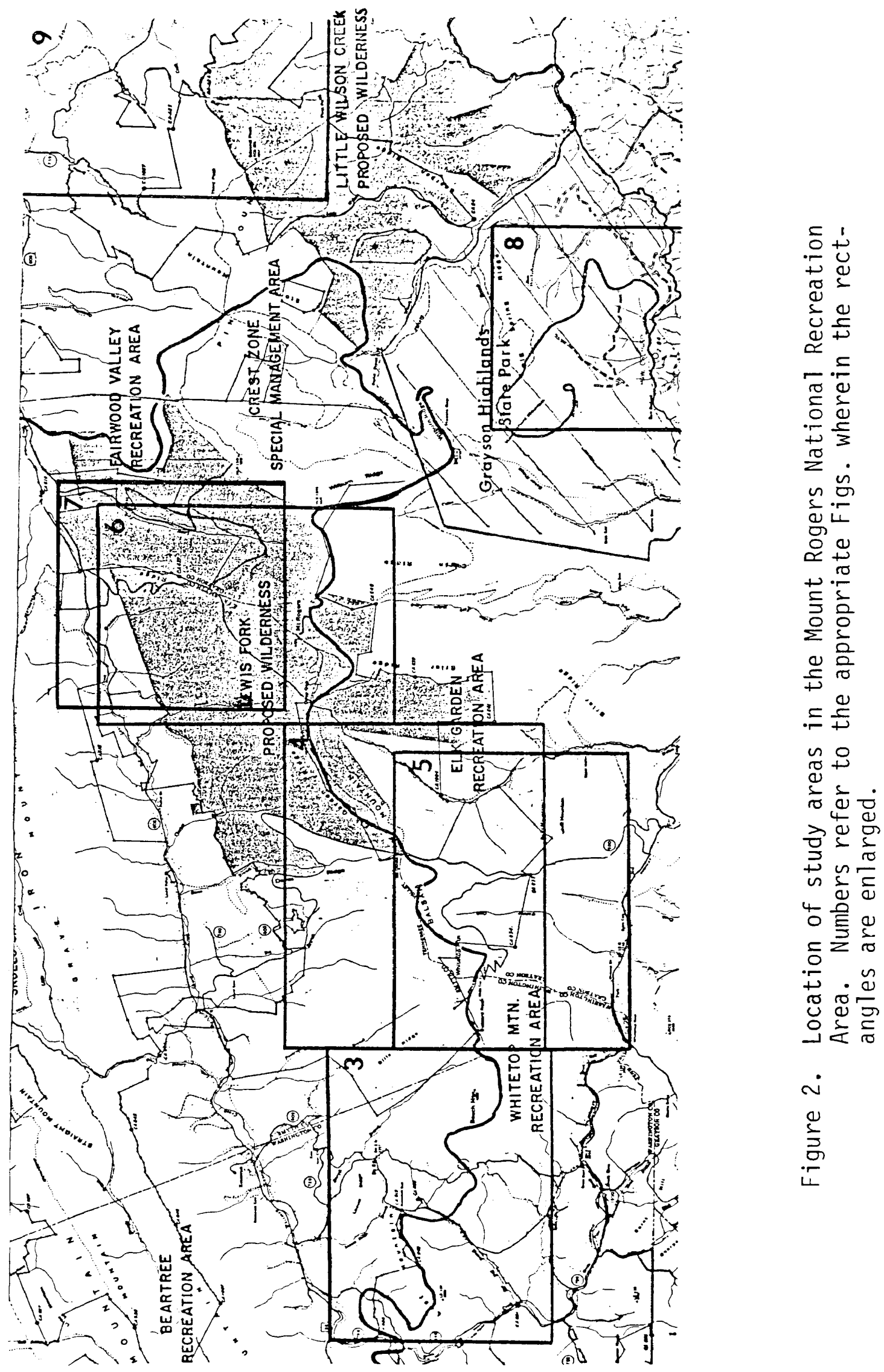




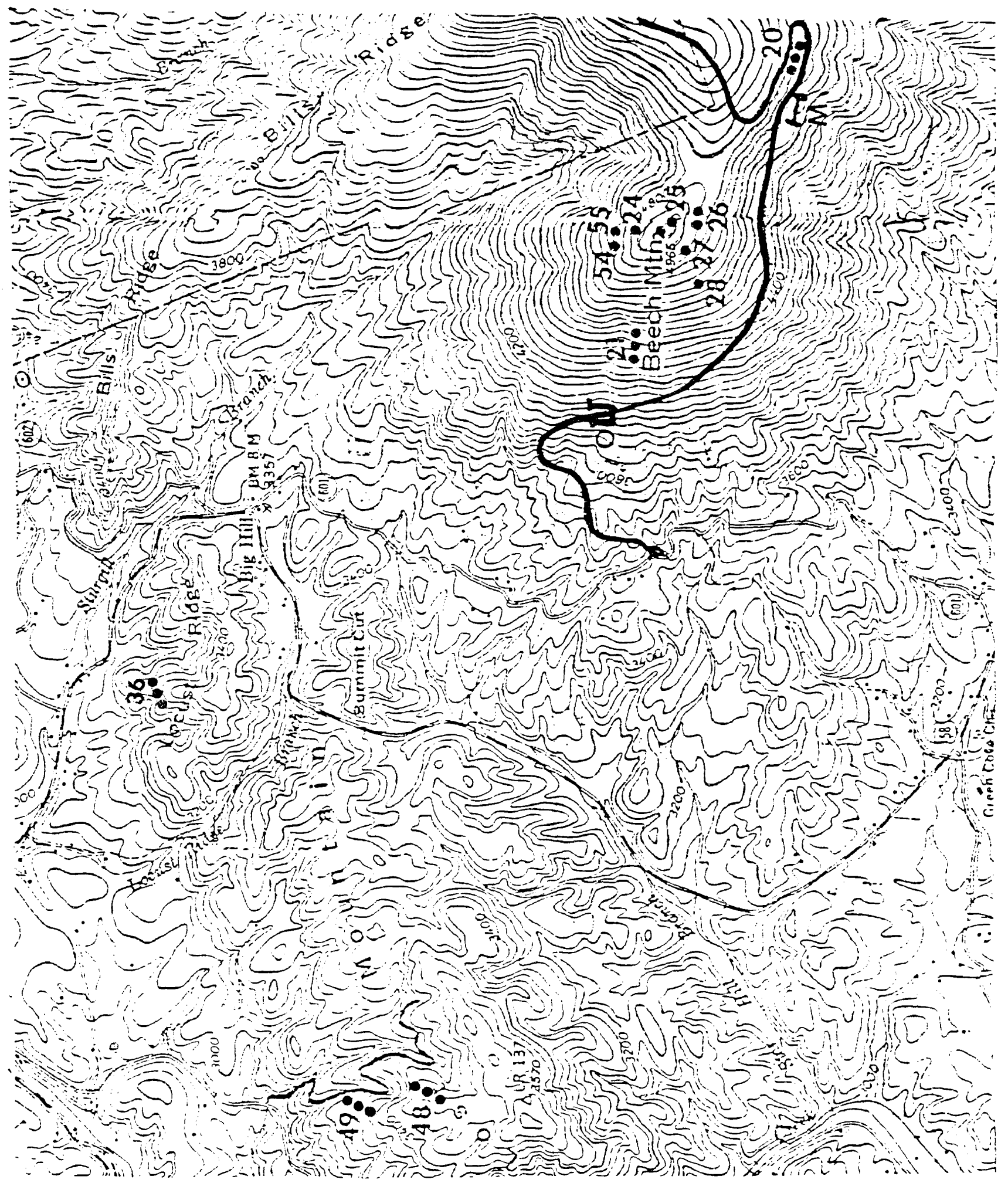

Figure 3. Lost Mountain and Beech Mountain study sites. Stand loacations are indicated by $(\bullet)$ and $(\mapsto)$. From USGS quadrangle maps "Konnarock" and "Whitetop". 


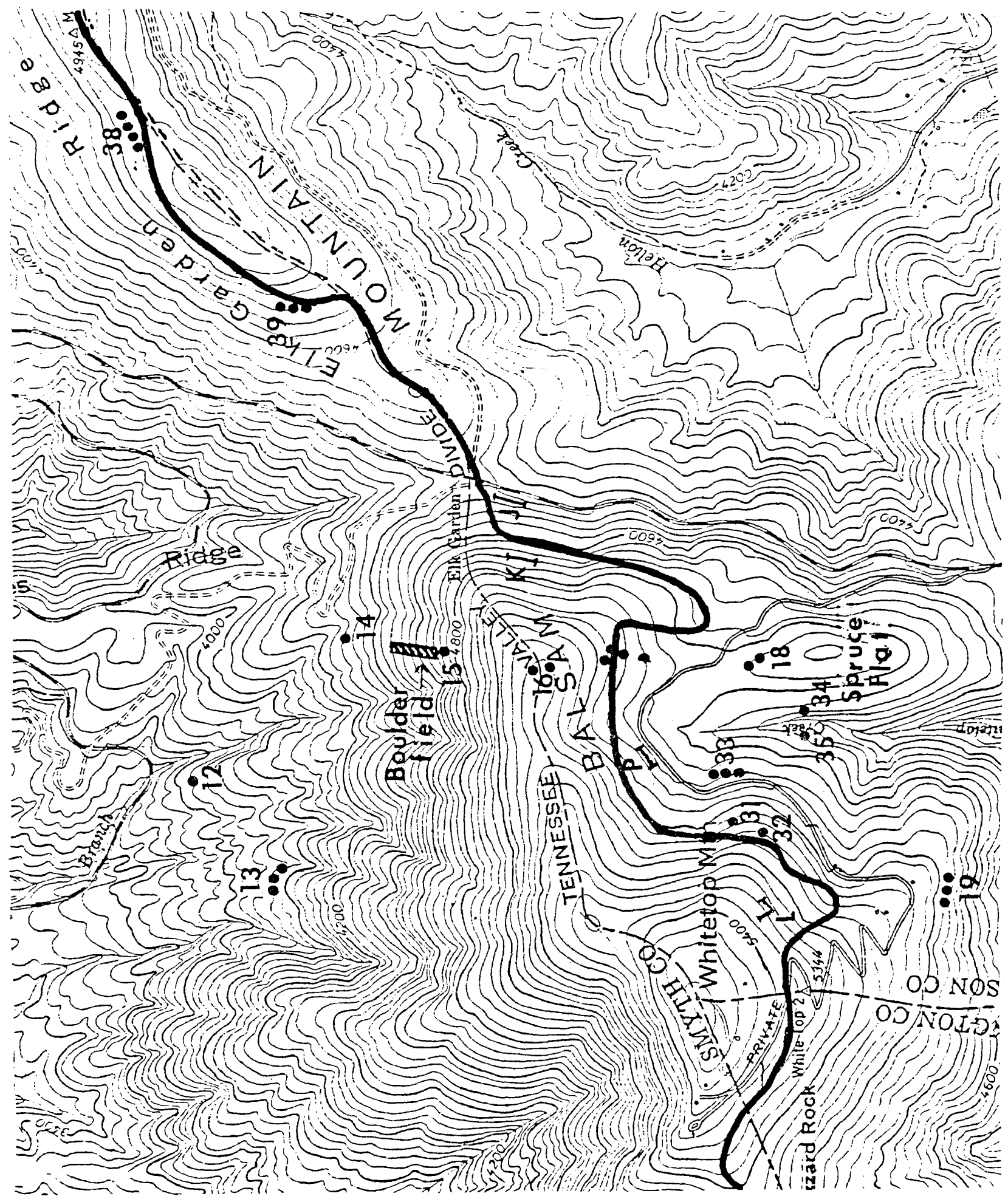

Figure 4. Whitetop Mountain and Elk Garden Ridge study sites. Stand locations are indicated by $(\bullet)$ and $(\longmapsto)$. From USGS quadrangle map "Whitetop". 


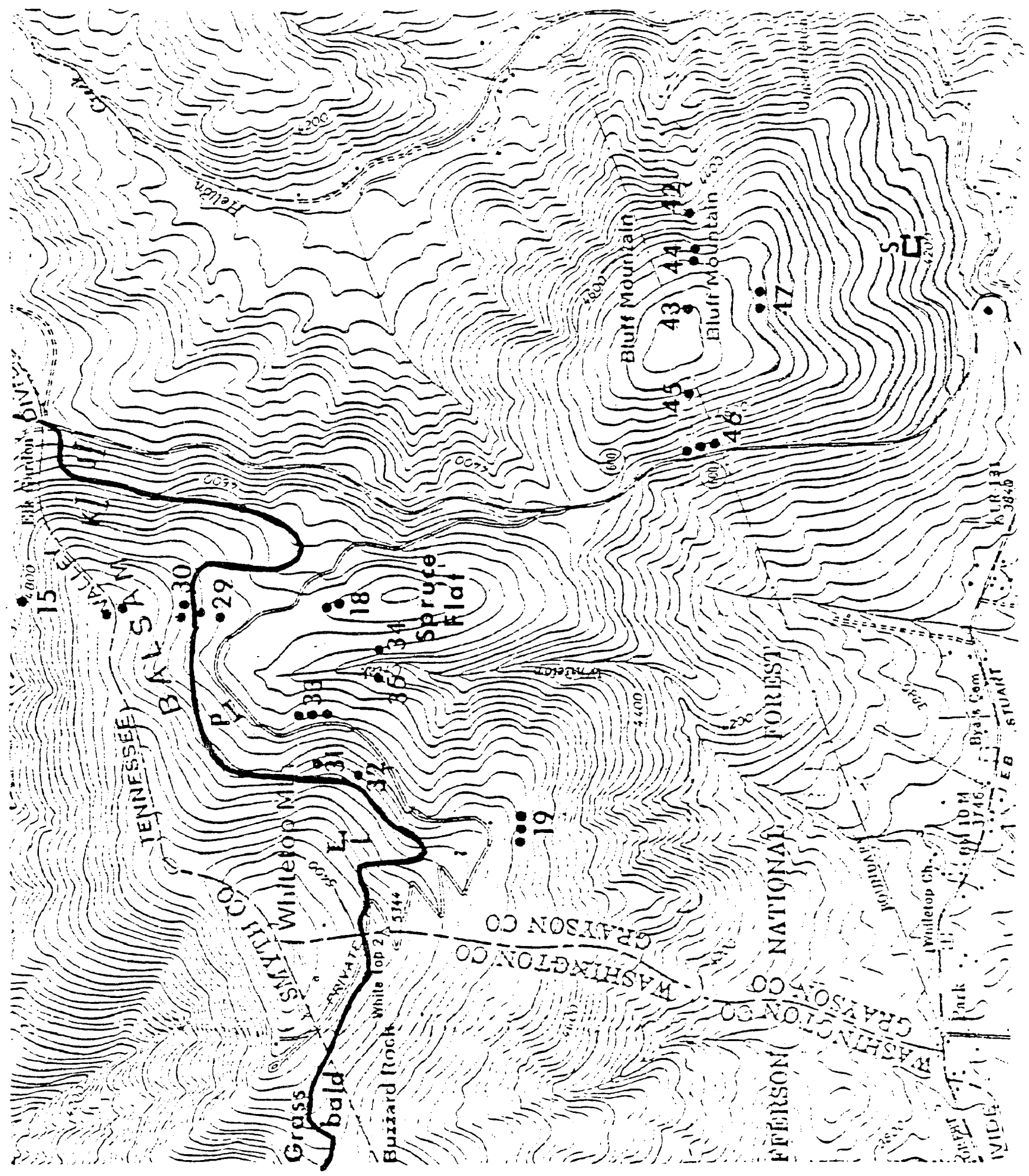

Figure 5. Whitetop Mountain and Bluff Mountain study sites. Stanci locations are indicated by $(\bullet)$ and $(\mapsto)$. From USGS quadrangle map Whitetop. 
10.

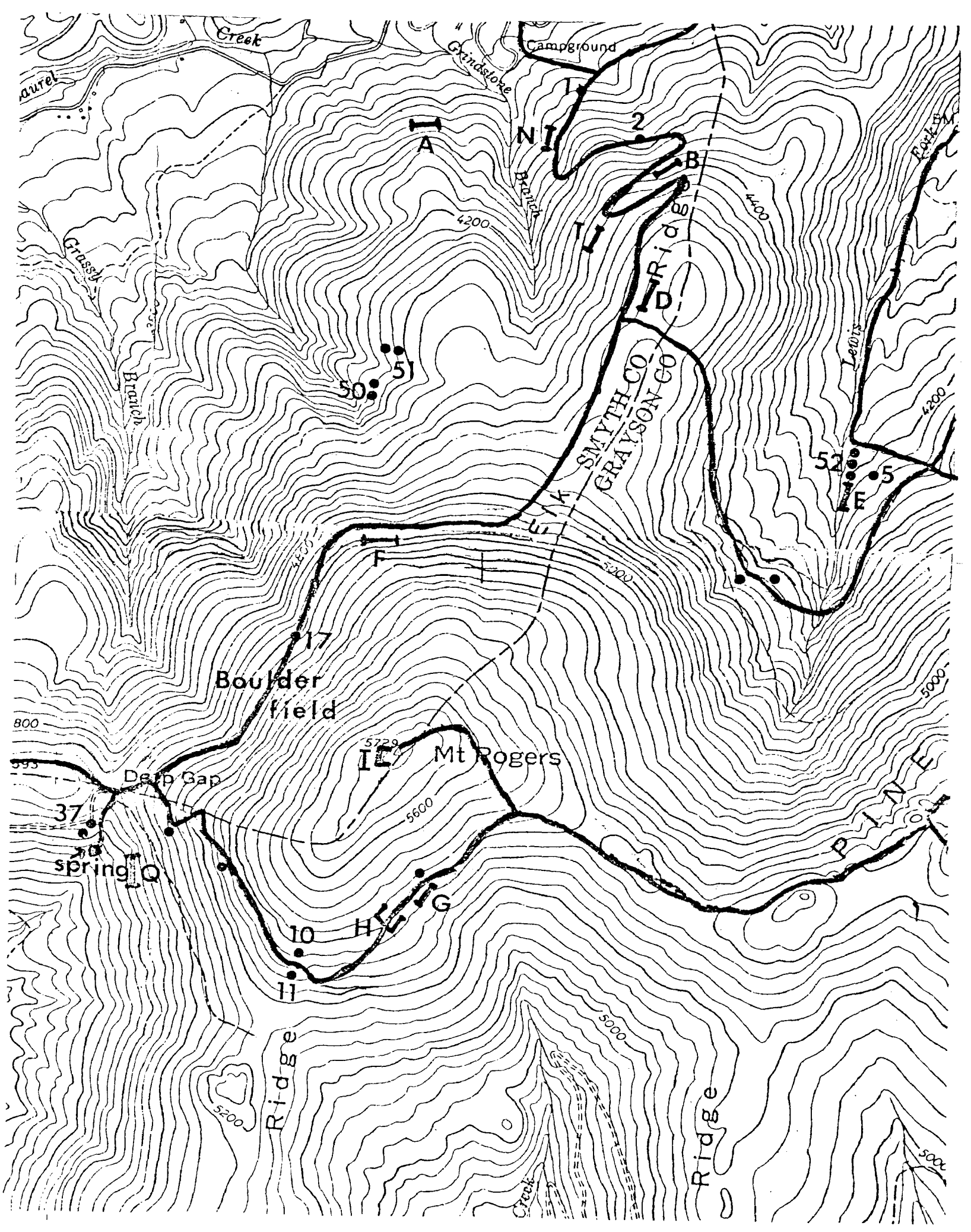

Figure 6. Mount Rogers and Lewis Fork study sites. Stand locations are indicated by $(\bullet)$ and $(\mapsto)$. From USGS quadrangle map "Whitetop". 


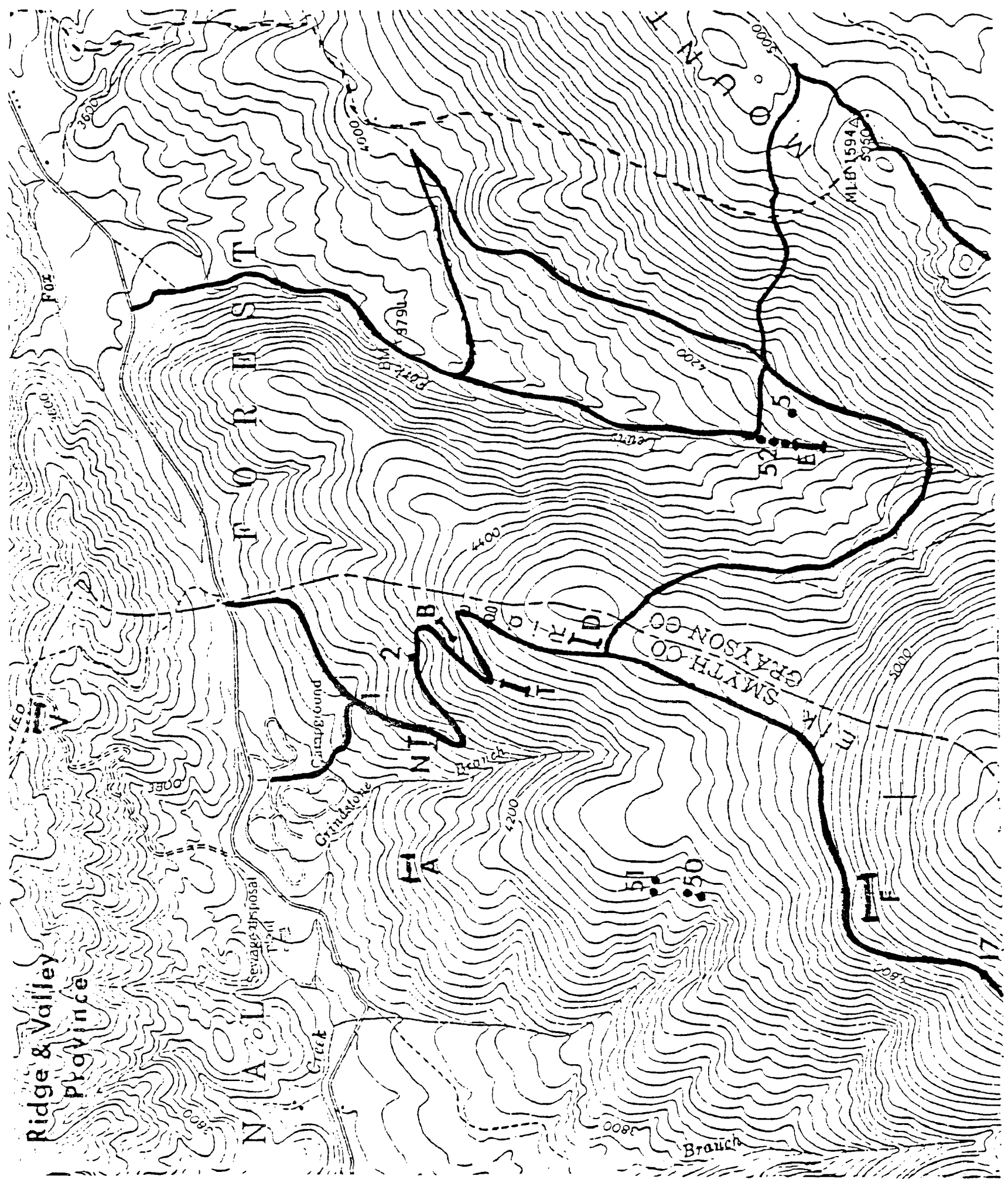

Figure 7. Mount Rogers, Elk Ridge, and Lewis Fork study sites. Stand locations are indicated by $(\bullet)$ and $(-1)$. From USGS quadrangle map "Whitetop". 


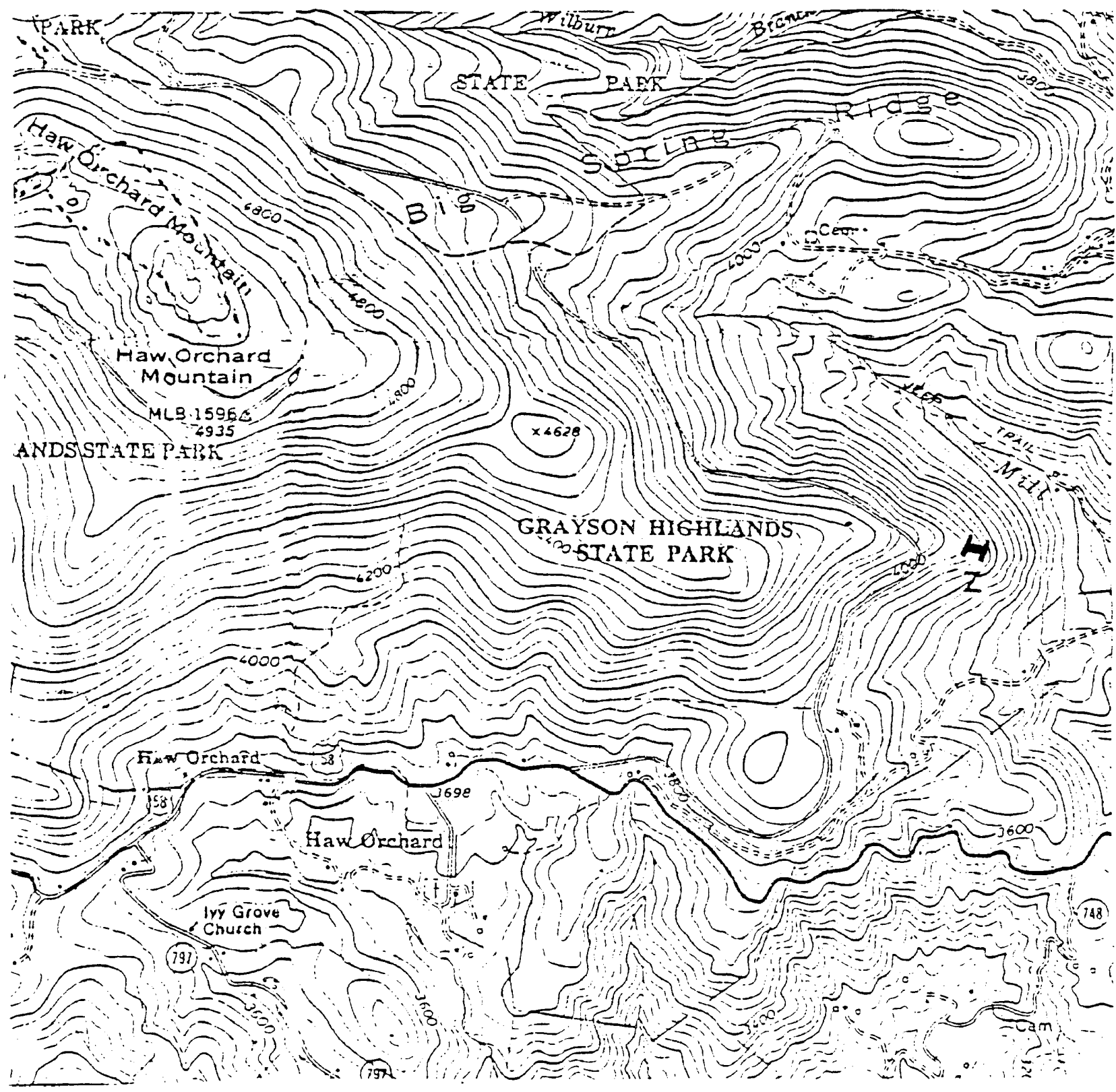

Figure 8. Haw Orchard Mountain study site. Stand location is indicated by $(\longmapsto)$. From USGS quadrangle maps "Grassy Creek", "Whitetop", and "Troutdale". 


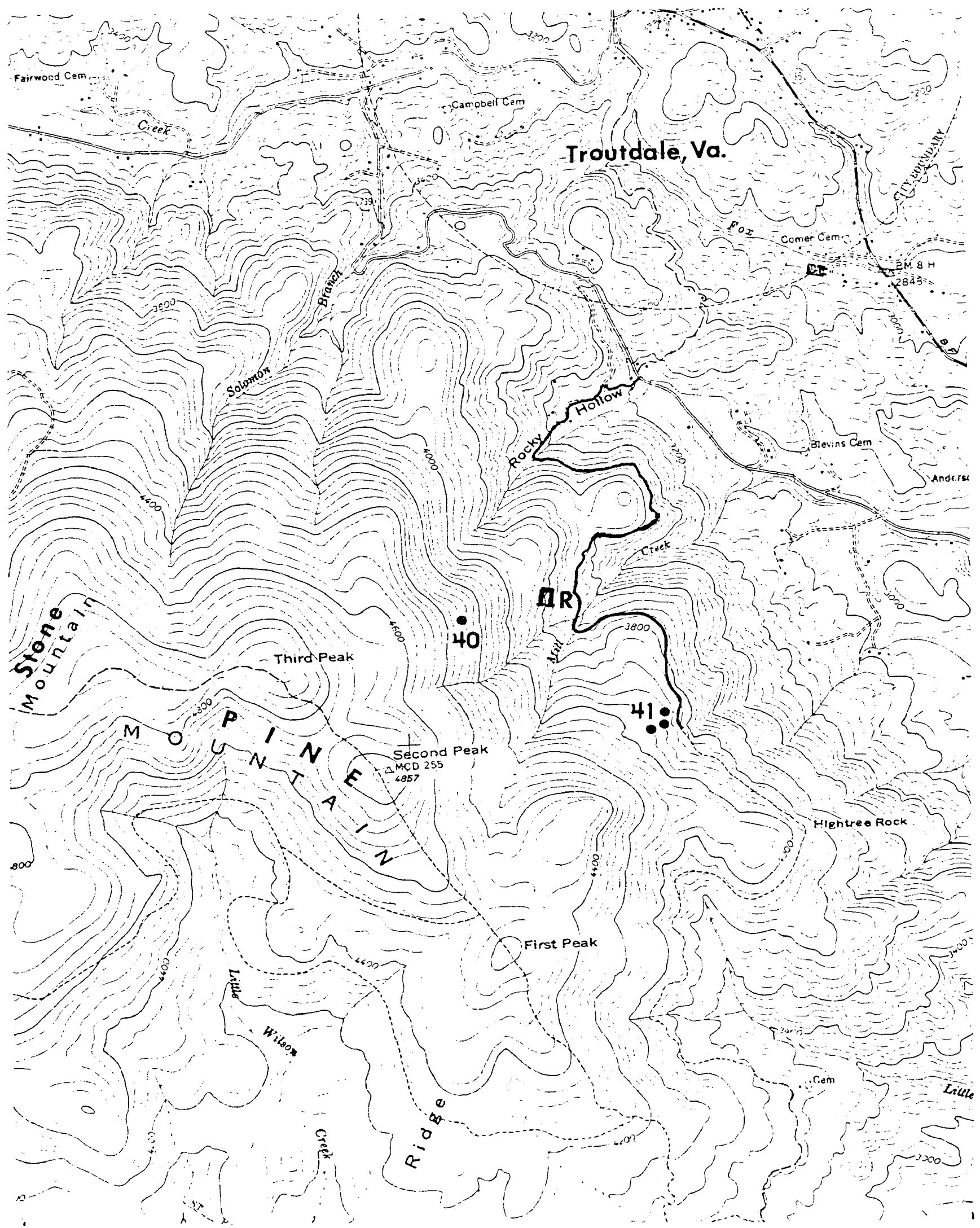

Figure 9. Pine Mountain and Mill Creek study sites. Stand locations are indicated by a $(\bullet)$ and $(\mapsto)$. From USGS quadrangle map "Troutdale". 
The wide elevational range and diverse topography of these mountains undoubtably affects the vegetation by influencing such habitat parameters as precipitation, temperature, insolation, and wind velocities. Unfortunately, very few data on these variables are available. Temperture, precipitation, and some wind data were collected from the summit of Whitetop Mountain between 1947 and 1951 by the Tennessee Valley Authority. The U.S. Weather Bureau collected precipitation data for Troutdale, Virginia, located $11 \mathrm{~km}$ northeast of Mount Rogers at an elevation of approximately $950 \mathrm{~m}$. In addition, recent precipitation and temperature records from the summit of Mount Rogers were made available by Dr. Philip Shelton of Clinch Valley College.

\section{Precipitation}

For a four period from May 1, 1947 to Apri1 31, 1951, the Tennessee Valley Authority collected moisture data near its installation just below the summit of Whitetop Mountain at an elevation of $1667 \mathrm{~m}$. Those data, in addition to those collected between 1934 and 1951 in Troutdale, Virginia by the U.S. Weather Bureau are condensed into monthly averages in Fig. 10 .

The greatest precipitation consistently occurred during the summer months (June, July, and August), averaging $18 \mathrm{~cm}$ per month. Occassionally, however, more than $33 \mathrm{~cm}$ per month was recorded. Recent data collected on Mount Rogers' summit during the summer of 1980, while this vegetational study was being conducted, indicated an average monthly rainfa11 of on $1 y$ $14.5 \mathrm{~cm}$. However, the summer of 1980 was unusual1y dry throughout the state of Virginia as well as on Mount Rogers. 


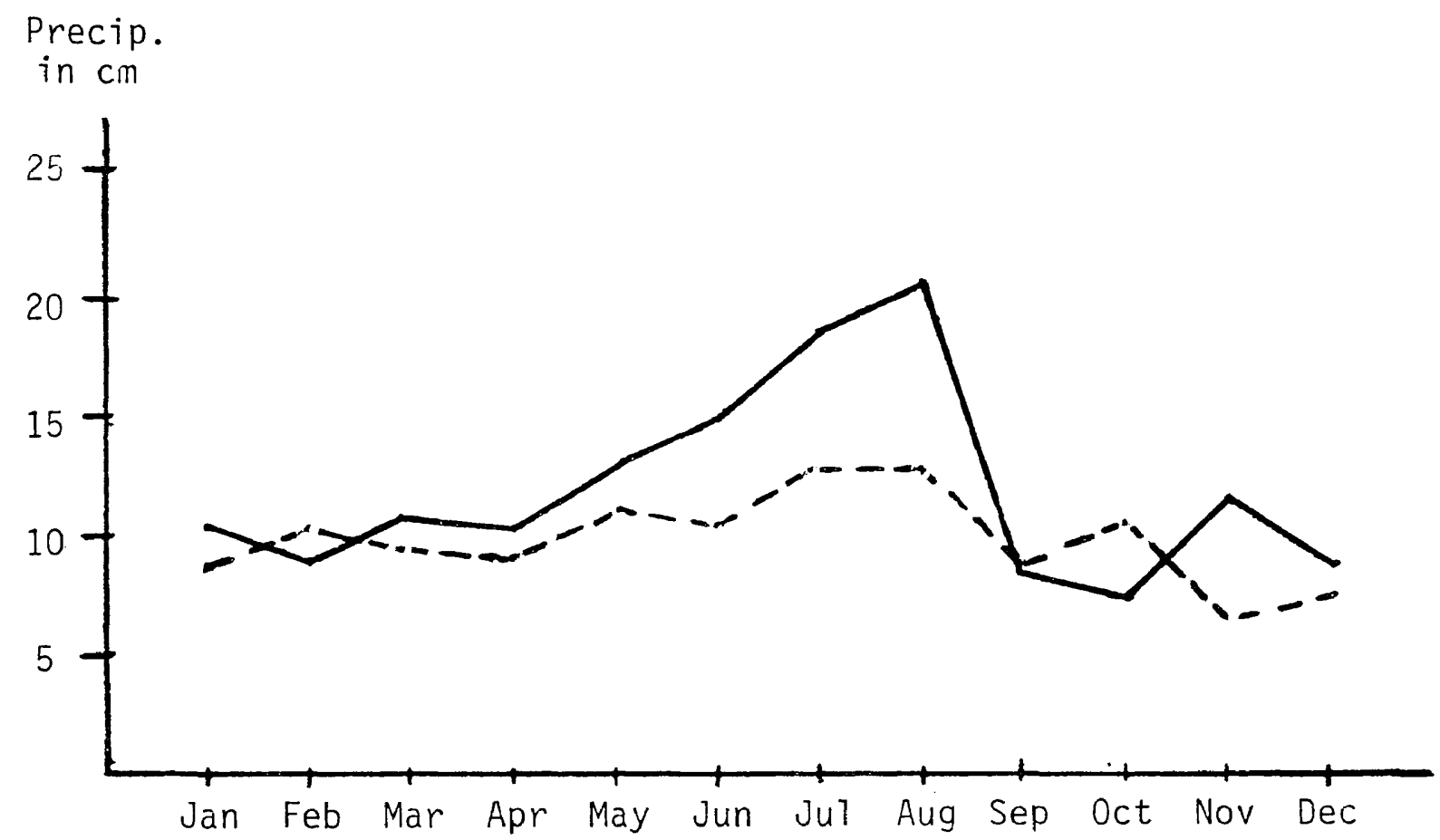

Figure 10. Average mean precipitation by months for Whitetop Mountain (solid line) and Troutdale, Virginia (broken line). Whitetop Mountain data collected at $1667 \mathrm{~m}$ in elevation over the period 1947 to 1951. Toutdale data, collected at $951 \mathrm{~m}$ in elevation, is based on normal temperatures averaged over the period 1938 to 1951. 
Climate

Temperature data was collected by the TVA (1947-1951) near Whitetop's summit at an elevation of $1667 \mathrm{~m}$. Figure 11 summarizes the data according to months. The average annual temperature was $7.2^{\circ} \mathrm{C}$ with minimum and maximum temperatures ranging between $-26.6^{\circ}$ and $+26.6^{\circ} \mathrm{C}$. June, July, and August were the warmest months while December, January, and February were the coldest.

Elevation inversely affects ambient air temperatures. Whittaker (1956:4) and 0osting (1956:107) estimate that mean average air temperatures decrease approximately $.406^{\circ} \mathrm{C}$ per $100 \mathrm{~m}$ increase in elevation. If this is so, then temperatures on the summit of Mount Rogers should average about $3^{\circ} \mathrm{C}$ cooler than the subjacent valleys at the $1000 \mathrm{~m}$ elevation and average about $7^{\circ} \mathrm{C}$ cooler than the Coastal Plain to the east.

Winds

Wind direction and velocity data for Whitetop Mountain were recorded for a 16 month period in 1949 and 1950 by the TVA in conjunction with thw U.S. Weather Bureau and radio station WOPI. The measuring equipment was placed on a radio tower $13 \mathrm{~m}$ above the tree tops at an elevation of $1711 \mathrm{~m}$. Figure 12 depicts average wind velocities for the months in which data were available. Winds were predominantly from the west with an annual average velocity of $30 \mathrm{~km}$ per hour. The highest winds seemed to occur during the winter months (December, January, and February) with the lowest occurring during the growing season (May through August).

Geology

The Balsam Mountains are a part of the southern Blue Ridge Province, 


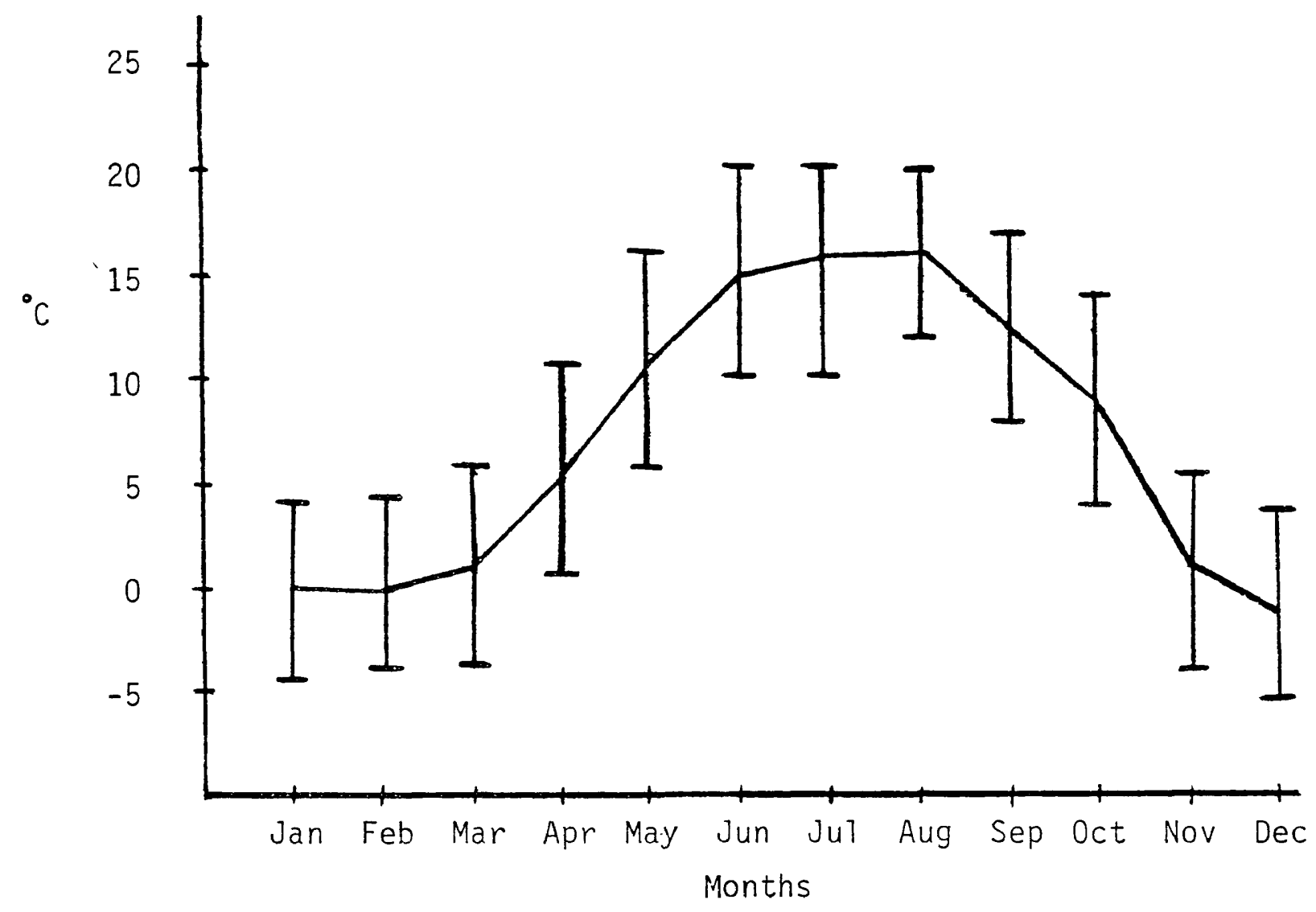

Figure 11. Average minimum, maximum, and mean temperatures by months for Whitetop Mountain. Data collected near the summit over the period 1947-1951. 
$\mathrm{km} / \mathrm{hr}$

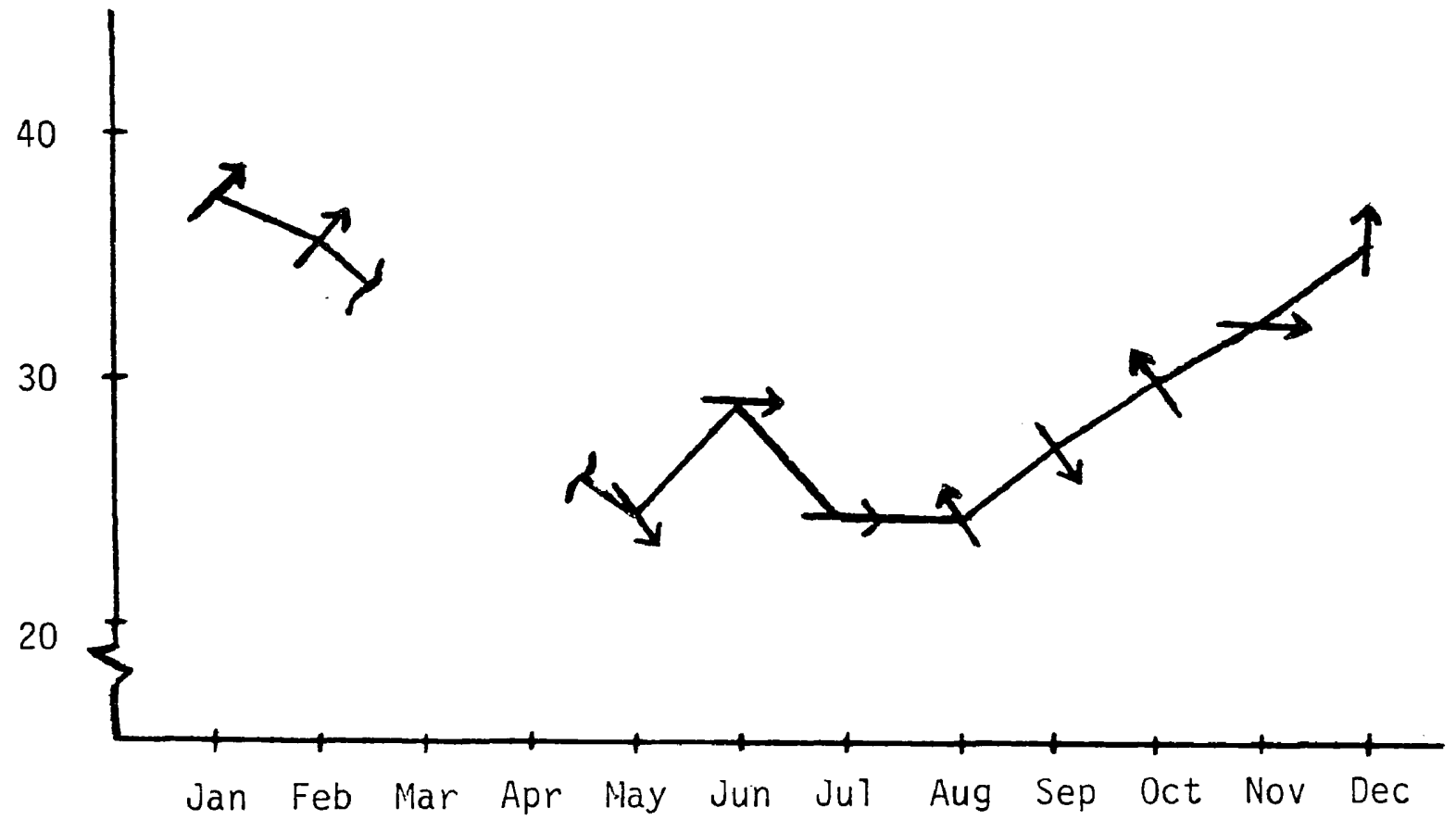

Figure 12. Mean wind velocity and prevailing direction $(\rightarrow)$ by months for Whitetop Mountain at an elevation of $1711 \mathrm{~m}$, averaged over a 16 month period during 1949 and 1950 . Ice damage resulted in a loss of record for March and Apri1. 
a geologically complex system of mountains composed primarily of metamorphosed igneous and sedimentary rocks (Fig. 13). The Balsams, which consist of the Mount Rogers and Whitetop massifs, is bordered on the north by the Iron Mountains (the first range of the Ridge and Valley Province) and on the south by the Blue Ridge proper. These three ranges run parallel to each other in a southwesteriy direction.

The Balsams form the Tennessee Valley Divide apportioning the runoff between the New and Tennessee rivers. The watersdraining to the north of the divide flow to the Tennesssee River while waters draining the south flow to the New River.

The soils in the study area contain relatively high amounts of organic matter with correspondingly low pH values. At the higher elevations, the soil is poorly developed and consists predominantly of organic matter. The high elevation north slopes of both whitetop and Mount Rogers are extremely steep and are underlain by huge boulders of the igneous parent material. A thick, organic mat, anywhere from a few centimeters to several meters thick, and topped by mosses, is about al1 that covers these piles of boulders, with soil and inorganic minerals being almost entirely absent. Shields (1962) aptly called these rocky north slopes "boulder fields". Johnson and Ware (in press) and Braun $(1950 ; 223)$ reported north slope boulder fields of a similar nature in areas they studied in other parts of the Virginia Blue Ridge. 
20.

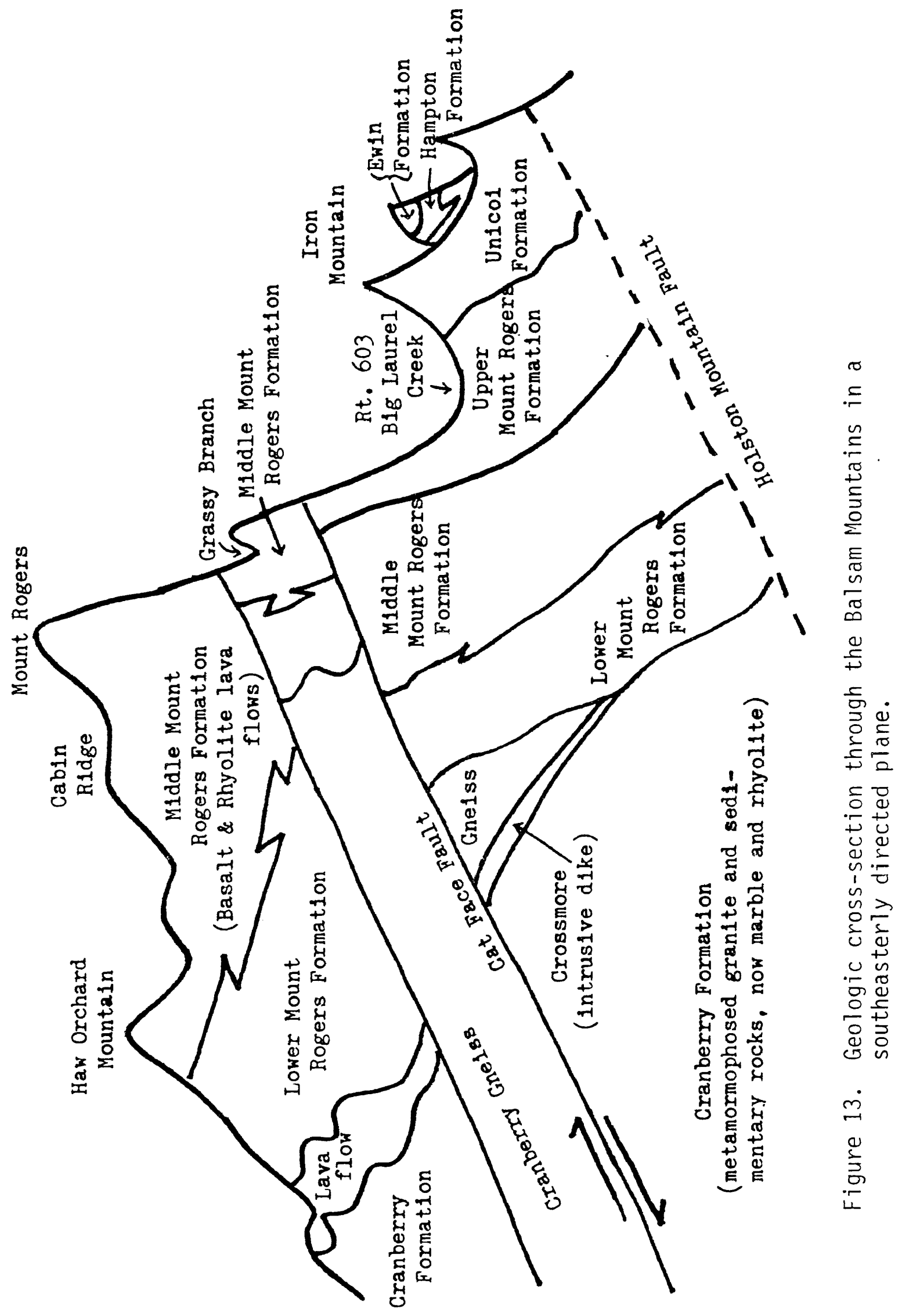


MATERIALS AND METHODS

Sampling procedures

Stand sites were located on U.S.G.S. quadrangle maps and then visited to check for suitability for sampling. An attempt was made to sample slopes facing each of the four cardinal directions within four elevational ranges - below $1150 \mathrm{~m}, 1150-1350 \mathrm{~m}, 1350-1550 \mathrm{~m}$ (transition from hardwoods to boreal coniferous forests), and 1550-1750 m. In addition, one sharp ridge, two ravines, three high elevation flats, and one stand in the adjacent Ridge and Valley Province were sampled in order to contrast these areas with the main sample area. These various categories were devised in order that almost all habitat types could be systematically visited. However, since grazed meadows and disturbed stands dominated most of the southern slopes, particularily at the lower elevations, southerly aspects were not as thoroughly represented.

Stands at the appropriate elevations and exposures were sampled only if they showed no recent evidence of disturbance, ie. did not appear to be successsional. Dominance was measured $\left(\mathrm{m}^{2} /\right.$ ha cross sectional area breast high) by the Bitterlich method (after Levy and Walker, 1971), using a Spiegal Relaskop (angle gauge). Densities of each species for trees (stems/ha) were based on counts of stems greater than $10 \mathrm{~cm}$ dbh $(1.5 \mathrm{~m})$ within a $10 \mathrm{~m}$ radius circle at each sample point. Densities for smaller size classes were determined by counting stems within a $5 \mathrm{~m}$ radius circle. These classes consisted of saplings (stems less than $10 \mathrm{~cm} \mathrm{dbh}$, but 
greater than $1.5 \mathrm{~m}$ high), larger seedlings (stems less than $10 \mathrm{~cm}$ dbh,

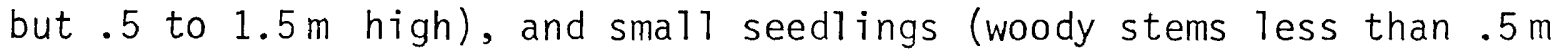
high). Saplings and larger seedlings were counted directly. Root suckers were included since there is good potential for them to become tree-sized individuals. The number of small seedlings were estimated as falling into one of six density classifications (Table 1). This was done because the actual numbers of the often very abundant small seedlings would be of dubious predictive value, since mortality in this size class is extremely high.

Herbaceous samples were taken at every woody species sample point and at points halfway between (approximately $15 \mathrm{~m}$ apart). At each point, a $1 \mathrm{~m}^{2}$ rope quadrat was placed on the ground and the percent cover of each species was estimated as falling into one of seven coverage classifications (Table 2) derived from Daubenmire (1968:43). As with woody species, the total number of sample quadrats was determined by a species/ area curve.

In each stand, notes were taken on general physiognomy, on the presence of dead stems, root sprouts, and relic individuals, and on the presence of herbaceous and woody species seen near the site, but not actualiy encountered in sample plots. In addition to the 21 sampled stands, 48 other stands of elevations and aspects similar to the sampled stands were visited to insure that the sampled stands were indicative of the general vegetational pattern of the area. At these "7isted" stands, basal area was quantitatively measured in the same manner as were the sampled stands, but no density counts were taken, and fewer ( 1 to 4) points were usually sampled. The presence of herbaceous species was noted along with general observations on the relative abundance of trees, saplings, and seedlings. 
Table 1 Stem density categories. Density estimates for smal1 seedlings (stems less than $.5 \mathrm{~m}$ high) occurring within a $5 \mathrm{~m}$ radius circle from the sample point.

Density range

Midpoint of range

(used in analysis)

10 individuals

5.0

$10-25$

17.5

$25-50$

32.5

50-75

62.5

75-100

87.5

100

100.0 
Table 2. Herbaceous coverage classifications. Coverage estimates for each species' occurrence within a $1 \mathrm{~m}^{2}$ enclosure.

$\begin{array}{cc}\text { Range of cover (\%) } & \text { Midpoint of range } \\ X^{1} & \begin{array}{c}\text { (used in analysis) } \\ 0-5\end{array} \\ 5-25 & 15.5 \\ 25-50 & 37.5 \\ 50-75 & 62.5 \\ 75-95 & 85.0 \\ 95-100 & 97.5 \\ 100 & 100.0\end{array}$

1 Present, but of no significant coverage 
Petrides (1959) and especially Newcombe (1977) were consulted for quick field identifications of woody and herbaceous species. Identifications were substantiated by using Radford et al. (1968), and nomenclature throughout this paper follows that of Radford et al. unless otherwise noted.

Environmental parameters were measured in order to determine whether any would correlate with community structure. Elevation was measured in all sampled and listed stands with a Thrommen altimeter which was set each day at the base camp and checked throughout the day against numerous known elevations. Aspect was determined in degrees with a Sunto RA-69 compass, and the degree of slope was measured at each sample point in a stand, and the values for each was averaged separately to get a mean value for each variable in the stand. In the 21 sampled stands and in four of the listed stands, approximately one half liter of soil was collected along the sample transects and sent to the Soil Testing and Plant Analys is Laboratory of the Virginia Polytechnic Institute and State University (V.P.I.) for pH and mineral analysis. Soil mineral content in parts per million was determined for phosphorus, potassium, calcium, magnesium, manganese, zinc, nitrate nitrogen, soluble salts, and percent organic matter. In order to compare soil moisture availability between stands, at least two Bouyoucos moisture blocks were buried under approximately $10 \mathrm{~cm}$ of soil in all of the sampled stands and in four of the listed stands. Field capacity was determined as percent moisture availability, using a Bouyoucos moisture meter, on at least three separate occasions more than one week apart. Readings of the several blocks within a stand were averaged. The abundance of small pebbles (clasts $4-64 \mathrm{~mm}$ in diameter) in the soil was subjectively estimated and classed into one of four categories (Table 3 ). 
Table 3. Pebble abundance categories. Categories of clasts 4 to $64 \mathrm{~mm}$ in diameter based on Wentworth's scale of particle size.

$0=$ No pebbles present, soil predominantly composed of organic matter.

1 = Mineral soil, only a few scattered pebbles present.

2 = Moderate abundance of pebbles, soil easily extracted for mineral analysis.

3 = Many pebbles, soil samples difficult to extract.

4 = Pebbles extremely abundant, soil samples extremely difficult to extract for analysis. 
Data Analysis

Sampling data analysis and subsequent manipulation was done using an IBM 370 Model 158 computer programmed in SAS and Pascal language. For each stand, the dominance (cross sectional area breast high) and density values of each species were used to calculate relative dominance and relative densities, and these two values were averaged to obtain an importance value for each species. In listed stands, only relative dominance was calculated since densities were not measured in these stands. Relative densities alone were calculated for each of the smaller size categories.

In each stand, all herbaceous species with greater than $1 \%$ coverage were assigned the midpoint values of their respective coverage classifications (Table 2). The midpoint values of all sample points were totaled and divided by the number of sample points to obtain each species' average total coverage in the stand. The frequency of occurrance of each species, and its maximum coverage in a sample plot were also calculated. An importance value was then determined by averaging the relative coverage and relative frequency values.

Ordinations

Three polar ordinations (Bray and Curtis, 1957;Poole, 1974) were constructed. One used relative dominance values of woody species (from the combined 69 sampled and listed stands), another used the importance values of woody species (from the 21 sampled stands), and the third used the importance values of herbaceous species (again from the 21 sampled stands). The procedure for constructing the ordination is summarized below. First, a coeffficient of similarity was calculated for each stand by using the formula: 


$$
C=\frac{2 W}{A+B}
$$

where $A=$ the sum of values (importance or relative dominance) of all species in one stand, $B=$ a similar sum for another stand, and $W=$ the sum of the lesser values common to the two stands being compared. Each stand's coefficient of dissimilarity with respect to every other stand was then computed by subtracting its coefficient of similarity from one. The stands were then plotted on an ordination axis in the following manner:

1) One of the stands belonging to the pair of stands with the greatest dissimilarity value was designated as the first reference stand and assigned the value of zero. The other stand of the pair was assigned to the other end of the axis, its distance from zero being equal to its coefficient of dissimilarity with respect to the first reference stand.

2) Each of the remaining stands were then plotted on the axis with respect to to the first two reference stands by the formula:

$$
X=\frac{L^{2}+D a^{2}-D b^{2}}{2 L}
$$

where $X=a$ stand's distance from the first reference stand, $L=$ the distance between the two reference stands (ie. their dissimilarity value), $\mathrm{Da}=$ the dissimilarity of the stand under consideration to the first reference stand, and $D b=$ the dissimilarity of that same stand to the second reference stand.

3) To separate vegetationally dissimilar stands which occurred near each other on this first axis, a second axis was constructed by assigning the stand with the highest $e^{2}$ value to be the third reference stand (the first reference stand of the $Y$ axis) where

$$
e^{2}=D a^{2}-x^{2} \text {. }
$$


4) The fourth reference stand, placed at the other end of the $Y$ axis, was the stand most dissimialar to the third stand, yet within close proximity ( \pm 10 units) to it on the $x$ axis.

The same procedure was followed in constructing a $Z$ axis, but with the stipulation that the fifth and sixth reference stands be stands that had not been previously assigned as reference stands.

The ordination thus produces a three dimensional mosaic wherein the position of each stand is a function of its vegetational composition. The position of the stands in relation to one another on the ordination can be used to help divide the stands into community-types. A11 three axes of the ordination can then be tested for significant correlations with the measured environmental parameters. In addition, relative dominance or importance values of individual species can be plotted separately on the appropriate ordination in order to more easily visualize the distribution of species with respect to community-types. These species plots were produced using importance values for herbaceous species and relative dominance values for canopy (tree-sized) individuals. Woody species importance values are not presented here on separate ordinations since the two ordinations, the one derived from relative dominance values and the other from importance values, appeared to separate the stands in a similar manner.

Diversity indices

Diversity indices were calculated from 1) herbaceous species importance values, 2) canopy species importance values, 3) canopy species dominance values (from both listed and sampled stands), and from 4) canopy, 5) sapling, and 6) larger seedling density values. The indices were calculated by using the Shannon-Weaver formula (Poole, 1974): 


$$
H^{\prime}=-\sum_{i=1}^{s} p_{i} \ln p_{i}
$$

30.

where $s=$ the number of species and $p_{j}=$ the proportion of the total number of individuals consisting of the $i^{\text {th }}$ species.

Correlation analysis

The Pearson product-moment coefficient of correlation was used to test the relatedness between, and among environmental variables, species' importance or dominance values, and the ordination axes. First, a correlation analys is was executed to determine the relatedness between the measured environmental variables. Second, in order to determine whether any of the measured environmental parameters might be related to the general development of the vegetation, a correlation analysis was executed to compare stand values on each of the three ordination axes with the measured environmental variables. This was done for both the herbaceous and canopy dominance ordinations.

The remainder of the analysis was concerned with testing the degree of relatedness among woody, and among herbaceous species, as well as testing each species' correlative relationship with the 17 environmental parameters. Importance values for herbaceous species occurring in the 21. sampled stands, and relative dominance values for canopy species occurring in the 69 listed and sampled stands were used in the analysis. For the smaller size classes of woody species (saplings, larger seedlings, and small seedlings), the correlation analysis used their relative density values collected from the 21 sampled stands.

In order to remove elevation as an overwhelmingly influential 
variable affecting correlations of canopy dominance, the 69 sampled and listed stands were divided into two categories: one composed of the two boreal coniferous forest stands of the higher elevations (stands 10, 18, $29,31,34, G, K, L$, andY), and the other consisting of all the undisturbed hardwood stands located above $1150 \mathrm{~m}$ in elevation. It was hoped that comparing stands more homogeneous with respect to elevation and composition (ie. deciduous vs. coniferous stands) might facilitate the detection of correlative relationships between species and those environmental parameters which might be otherwise masked by their relationships with elevation. 
RESULTS

Relative and absolute dominance values for woody vegetation, and importance values for herbaceous vegetation in all sampled stands are presented in Tables 7 through 15. Importance values and both absolute and relative density values for each of the four size classes of woody vegetation are presented in Appendix A, Tables 18 and 19. The data used to derive importance values for herbaceous species, ie. each species' relative frequency of occurrence in the sample plots, its percentage of total coverage in the stand, and its maximum coverage in a sample plot, are found in Appendix B, Table 20. Diversity indices $\left(H^{\prime}\right)$ for each stand are recorded in Appendix A, Table 23.

\section{Ordinations}

Stand positions for each of the three ordinations derived from the woody and herbaceous vegetational data are represented on a three axes plot designed to show depth of field (Figs. 14, 16, and 24). The axes pair contributing to the best separation of these stands are presented after the three axes plots in Figs. 15, 17, and 25. The ordination positions determined for each stand are located in Appendix A, Table 21. In addition, the values (ie. importance values or relative dominance values) of species which occur in a large number of stands or those showing relatively high values in fewer stands are recorded on separate three axes plots in Figs. 18-23 for woody species and in Figs. 26-29 for herbaceous species. 
33.

Figure 14. A polar ordination of listed and sampled stands (next page) derived from relative dominance values of woody species. Each color represents a different communitytype (ie. blue $=$ spruce-fir, green $=$ spruce, orange $=$ yellow birch, yellow = northern hardwoods with hatched blocks representing the dwarf orchard subtype, purple $=$ high elevation mixed mesophytic, red = northern red oak, gray = mesophytic-oak, and white = lower elevation stands). The origin of the three axes of the ordination is located in the back corner. Relative dominance values are plotted separately on this ordination in Figs. 18-32. Below, significant correlations between each of the three ordination axes and the measured environmental parameters; all correlations are positive unless denoted by a "-".

\begin{tabular}{|c|c|c|}
\hline \multirow[t]{2}{*}{ Axis } & \multicolumn{2}{|c|}{ Degree of significance } \\
\hline & .05 & .01 \\
\hline$x$ & & $\begin{array}{l}(-) \text { elevation } \\
\text { species diversity } \\
\text { pH } \\
\text { calcium } \\
\text { magnesium }\end{array}$ \\
\hline Y & $(-)$ soluble salts & $\begin{array}{l}(-) \text { elevation } \\
(-) \text { manganese }\end{array}$ \\
\hline Z & pebble abundance & $\begin{array}{ll} & \text { elevation } \\
(-) & \text { species diversity } \\
(-) & \mathrm{pH}\end{array}$ \\
\hline
\end{tabular}

Continued 
34.

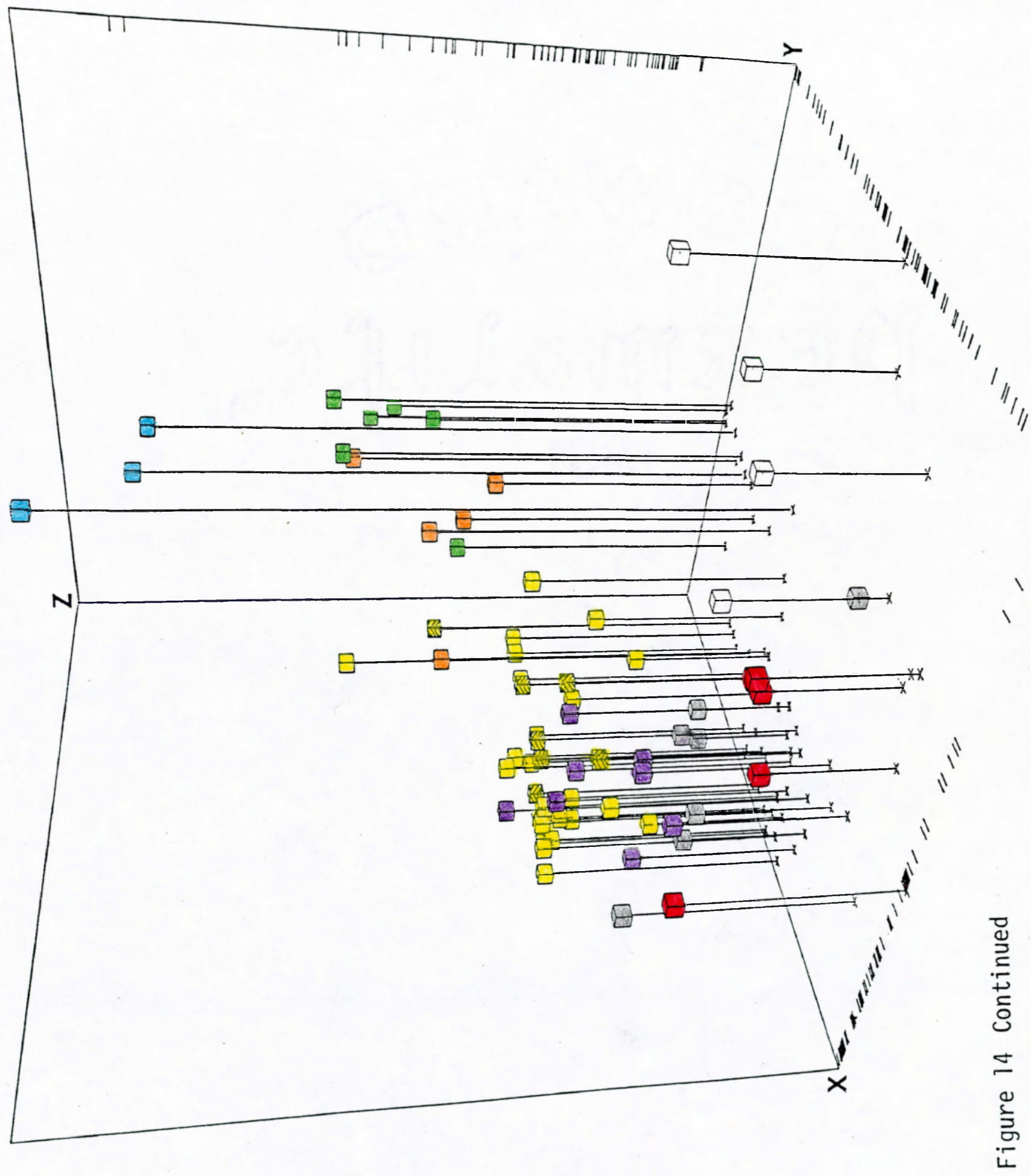


35.

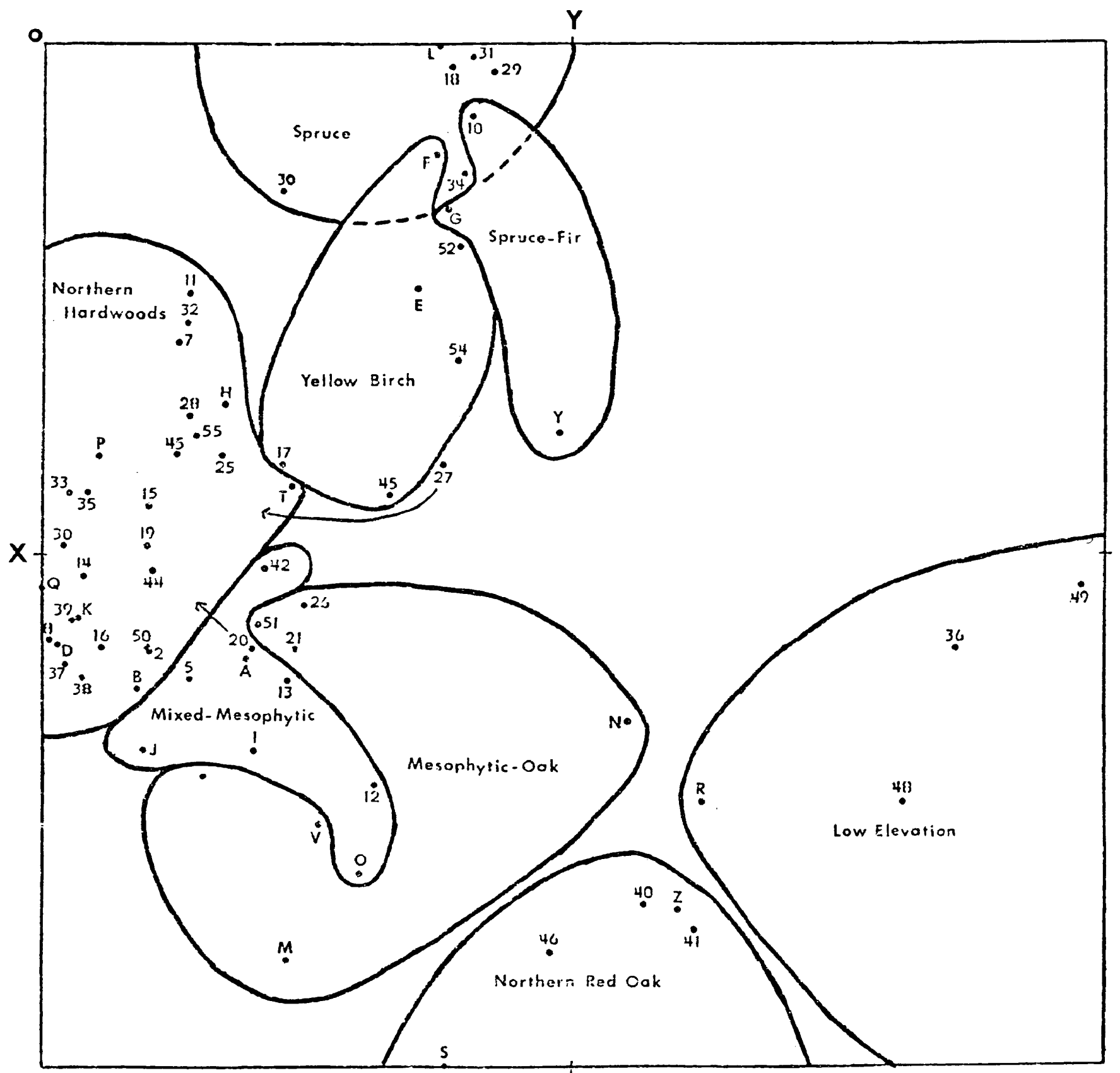

Figure 15. A polar ordination of listed and sampled stands, $X$ and $Y$ axes only, derived from relative dominance values of woody species. The origin is in the upper left hand corner in order to facilitate comparison with Fig. 15. Overlap of spruce-fir community-type (dotted line) exists in this two dimensional portrayal, however, greater separation of stands is evidenced using all three ordination axes (Fig. 14). 
36.

Figure 16. A polar ordination of sampled stands derived from woody species importance values (next page). Colors repesent community-types (see legend for Fig. 14 for color-coding). Origin of the three axes is at the back corner. Below, significant correlations between each of the three ordination axes and the measured environmental parameters; a11 correlations are positive unless denoted by a "-".

\begin{tabular}{|c|c|c|}
\hline \multirow[t]{2}{*}{ Axis } & \multicolumn{2}{|c|}{ Degree of significance } \\
\hline & .05 & .01 \\
\hline$x$ & $\begin{array}{l}\text { species diversity } \\
(-) \text { soluble salts } \\
\text { magnesium }\end{array}$ & $\begin{array}{l}(-) \text { elevation } \\
\mathrm{pH}\end{array}$ \\
\hline Y & $(-) \%$ organic matter & \\
\hline Z & (-) $\begin{array}{l}\mathrm{pH} \\
\text { soluble salts }\end{array}$ & \\
\hline
\end{tabular}

Continued 
Figure 16 Continued

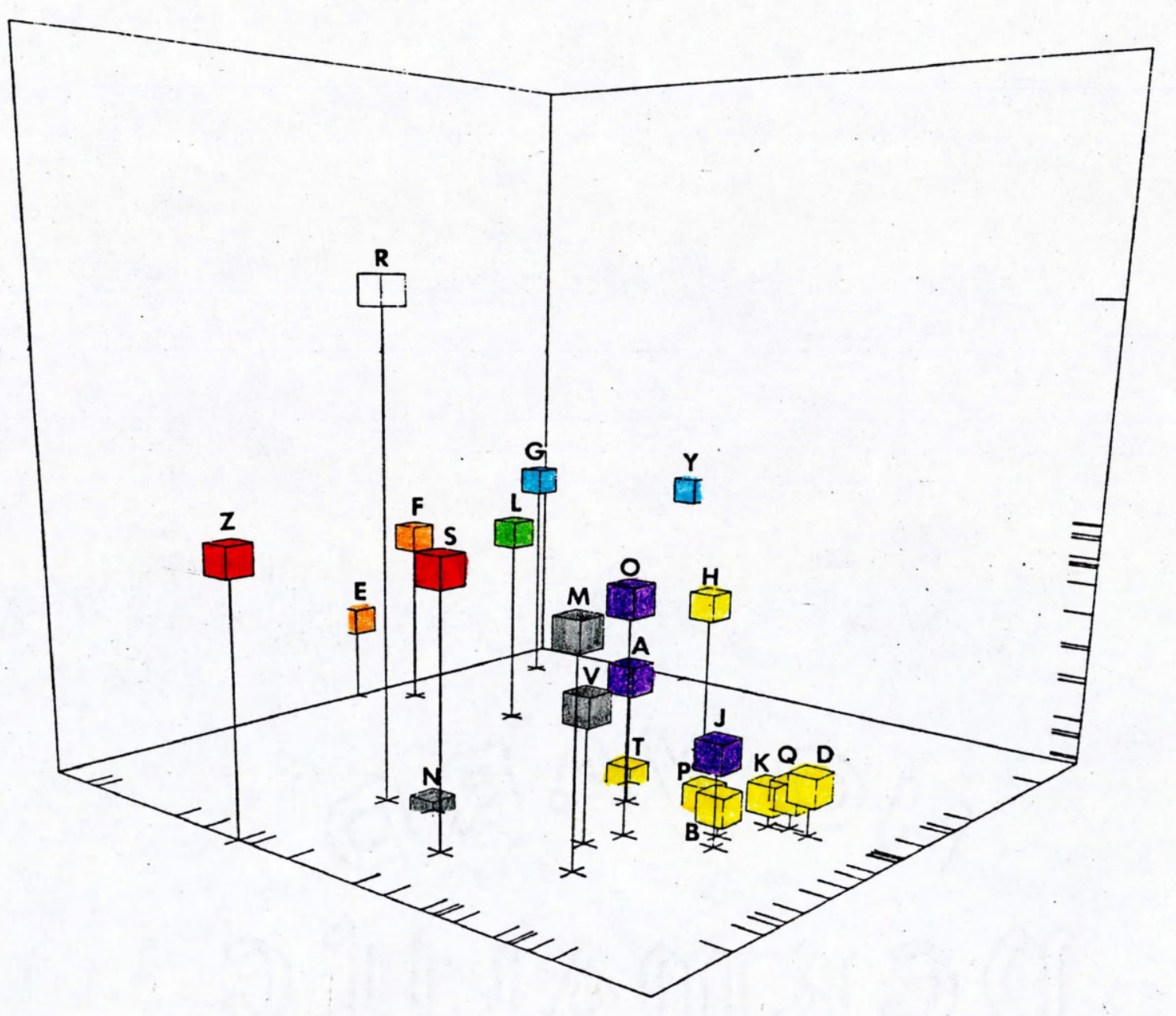




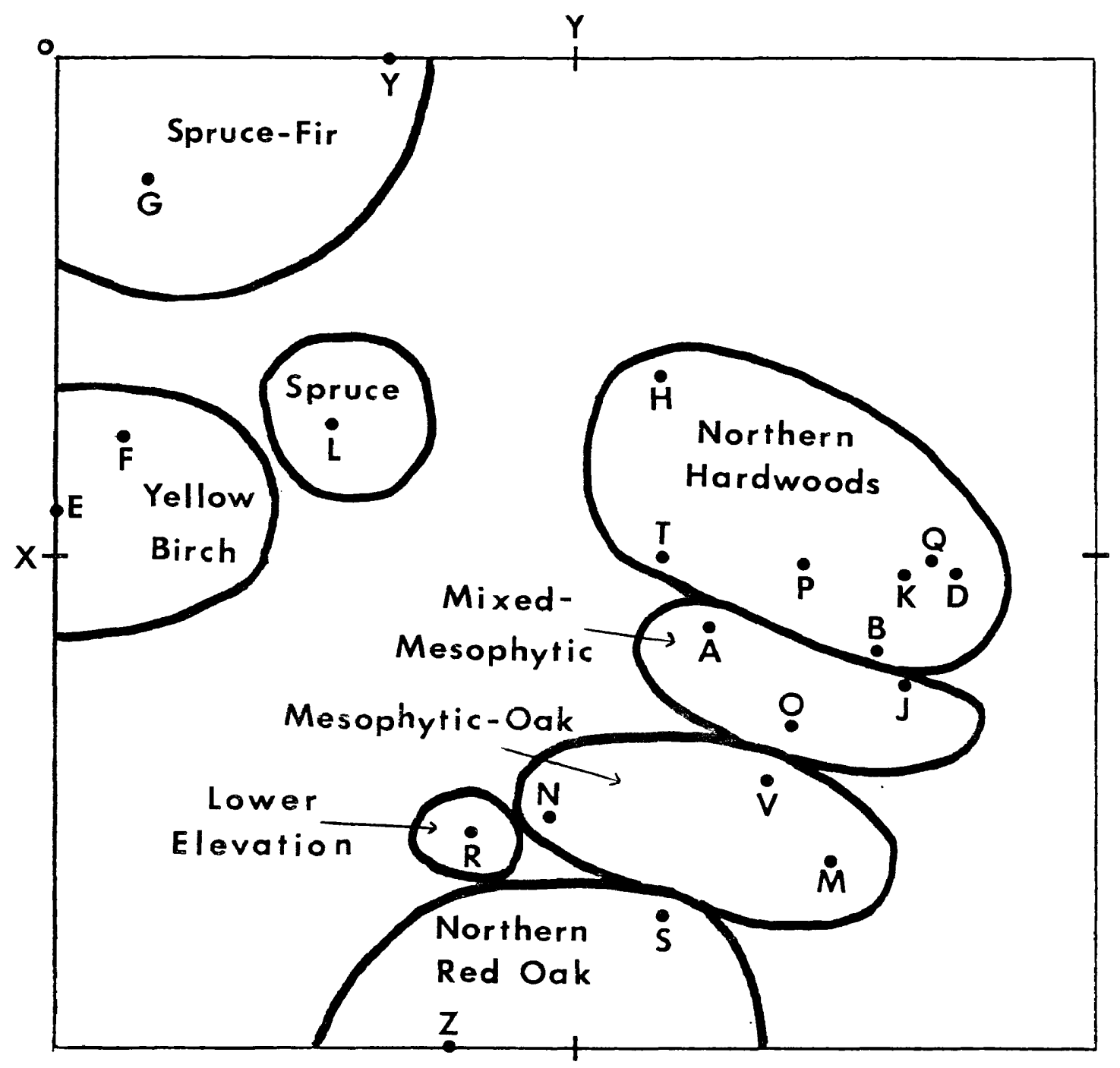

Figure 17. A polar ordination of sampled stands, $X$ and $Y$ axes only, derived from woody species importance values. The origin of the axes is located in the upper left hand corner in order to facilitate comparison with Fig. 16. 
39.

Figure 18. Relative dominance values of Abies fraseri (in parentheses) and Picea rubens with respect to stand positions on the polar ordination. All values of Picea greater than 10 were recorded, as were all values of Abies greater than zero. Refer to Figure 14 for legend. 
40.

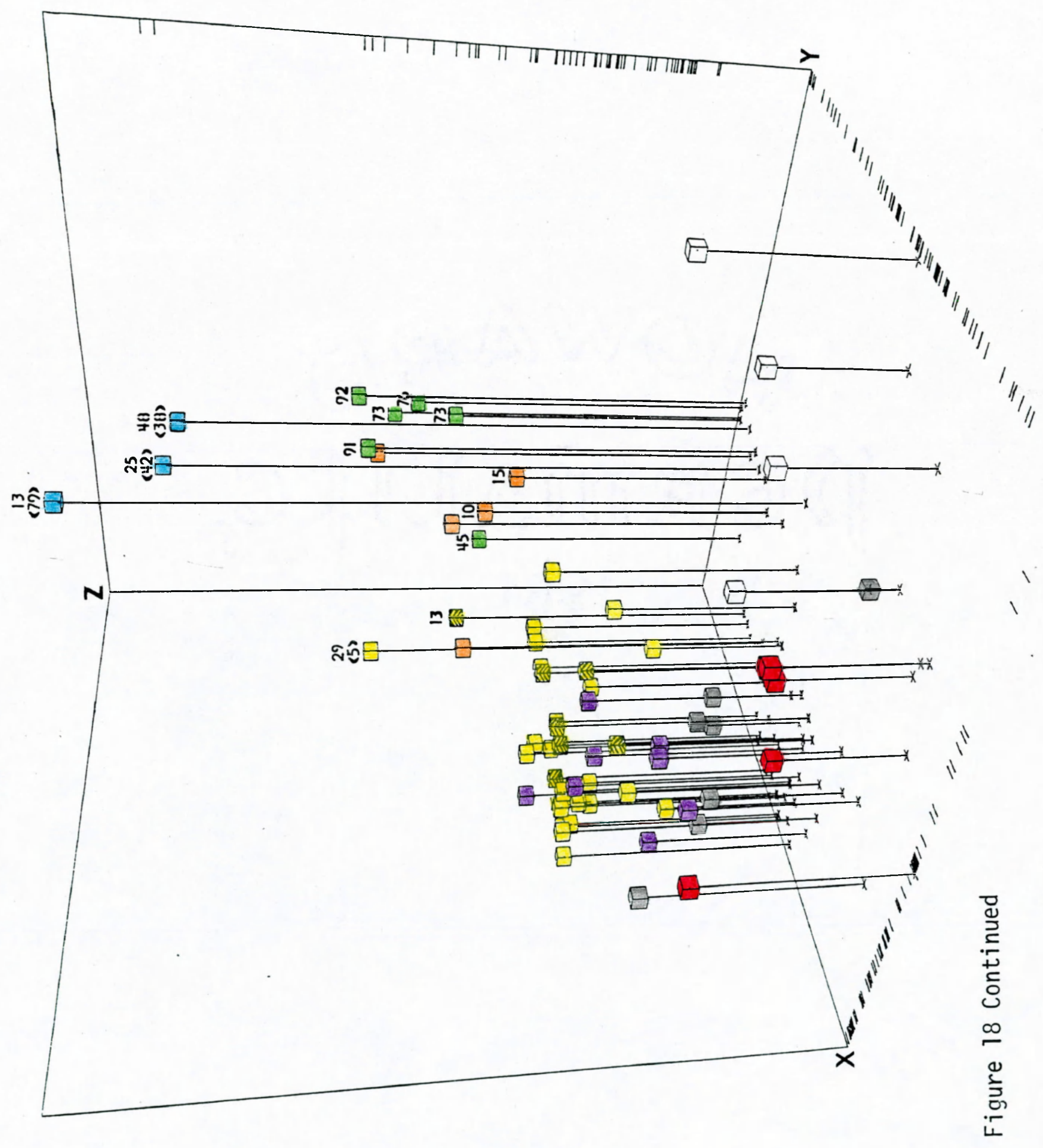


Figure 19. Relative dominance values of Betula lutea with respect to stand positions on the polar ordination. All values greater than 20 were recorded. Refer to Figure 14 for legend. 


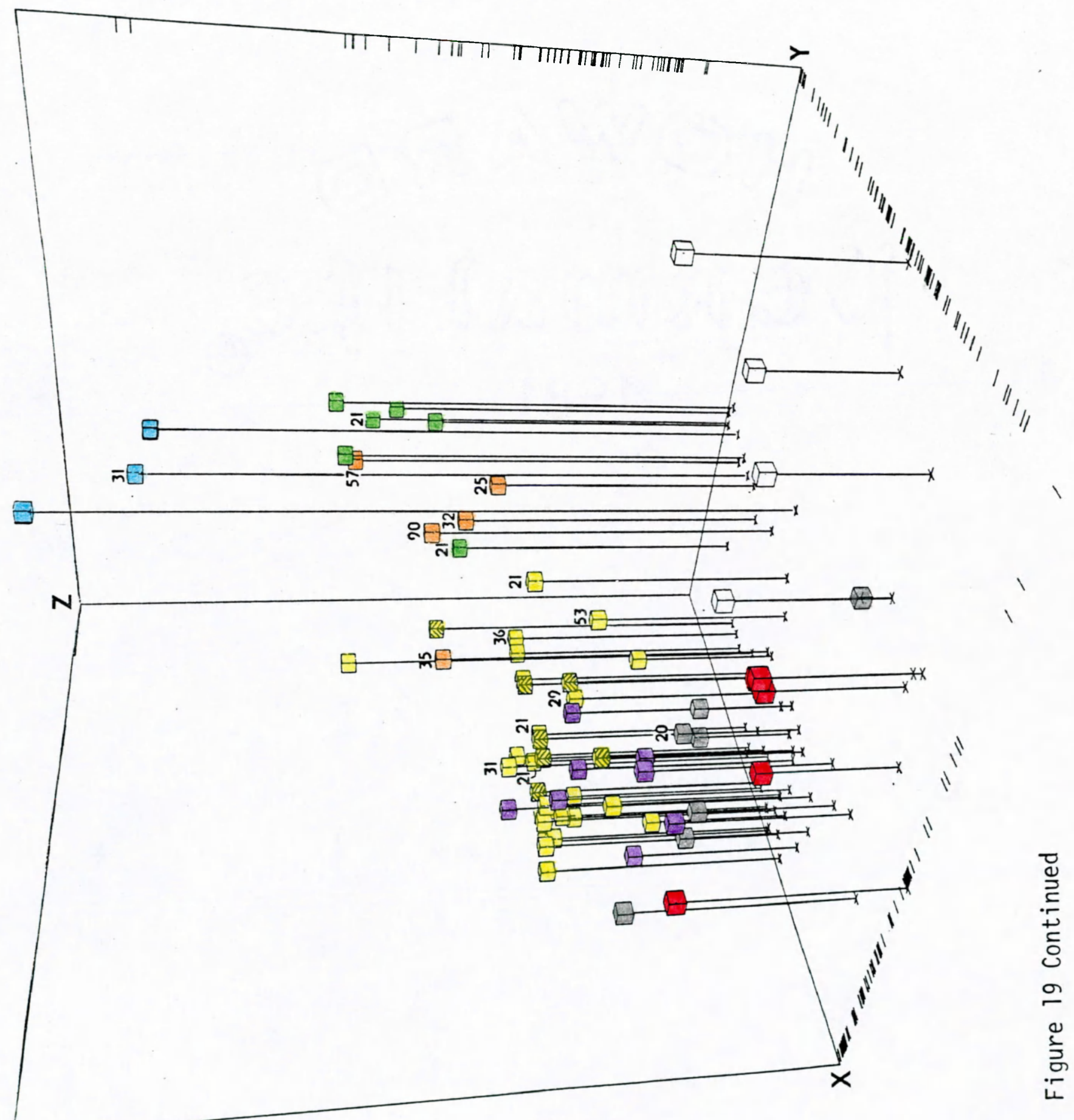


Figure 20. Relative dominance values of Fagus grandifolia with respect to stand positions on the polar ordination. All values greater than 40 were recorded. Refer to Figure 14 for legend. 
44.

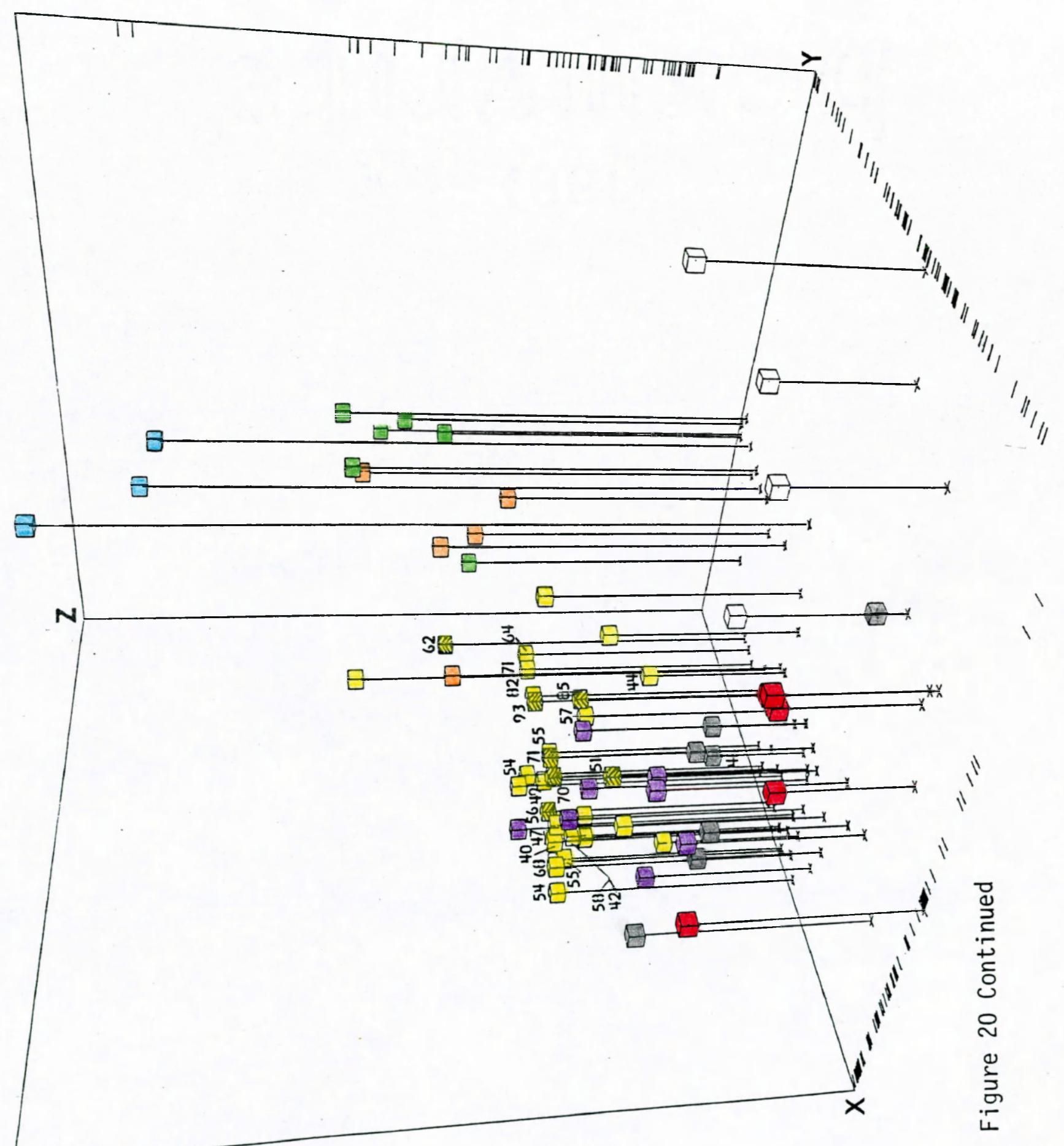


45.

Figure 21. Relative dominance values of Acer saccharum with respect to stand positions on the polar ordination. A 11 values greater than 30 were recorded. Refer to Figure 14 for legend. 
46.

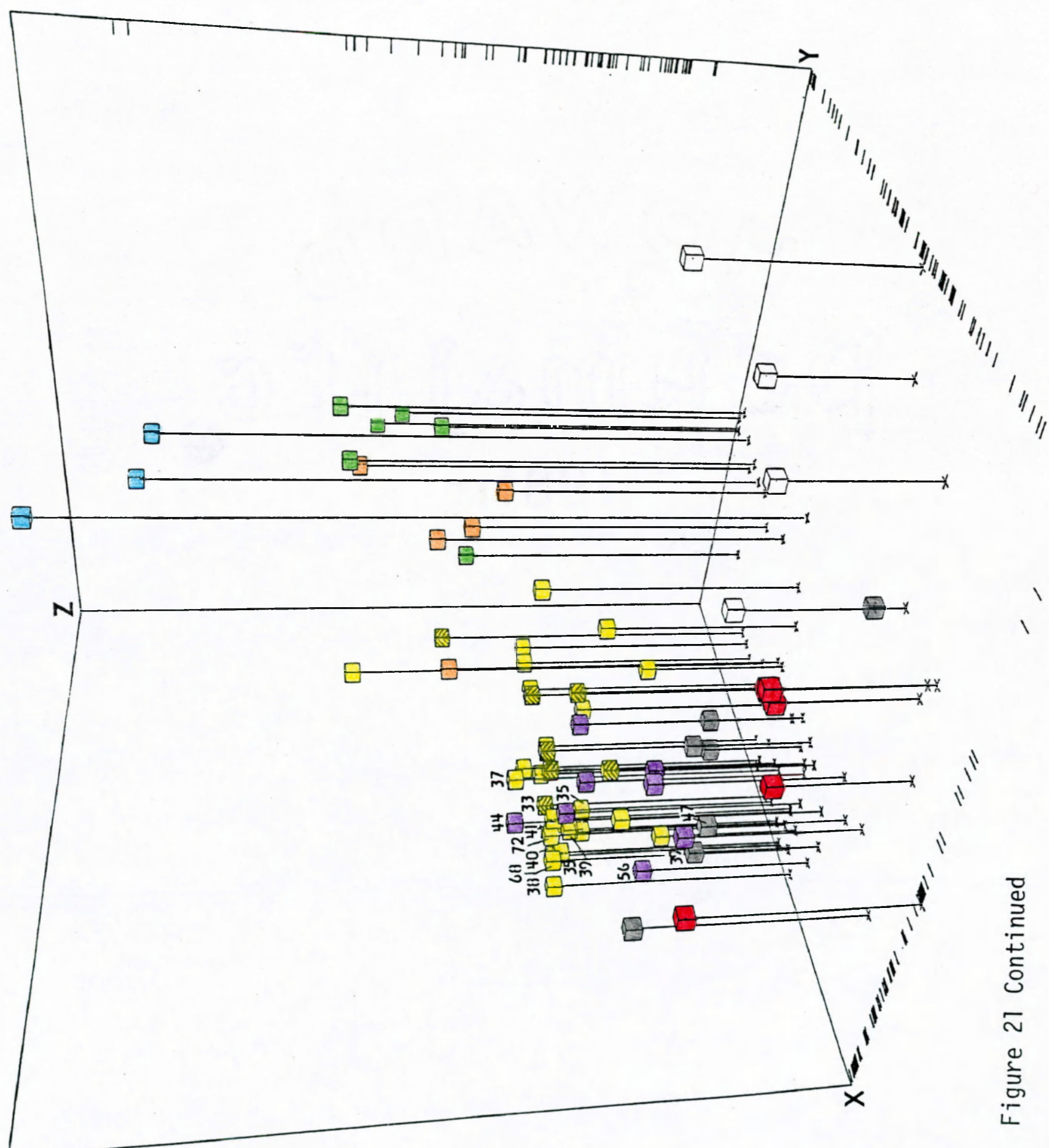


Figure 22. Relative dominance values of Tilia heterophylla with respect to stand positions on the polar ordination. A71 values greater than 8 were recorded. Refer to Figure 14 for 1 egend. 
48.

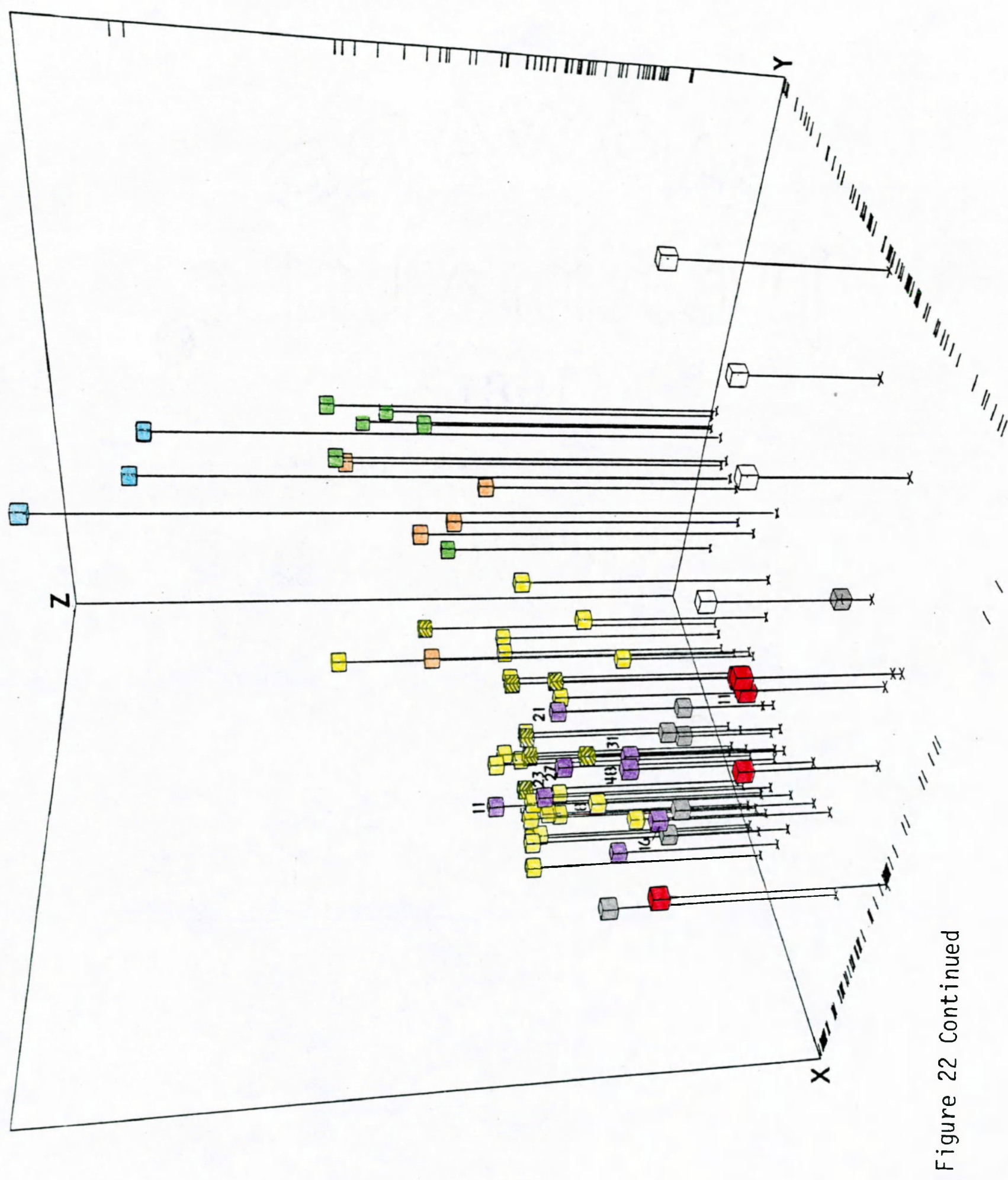


49.

Figure 23. Relative dominance values of Quercus rubra with respect to stand positions on the polar ordination. All values greater than 15 were recorded. Refer to Figure 14 for legend. 
50.

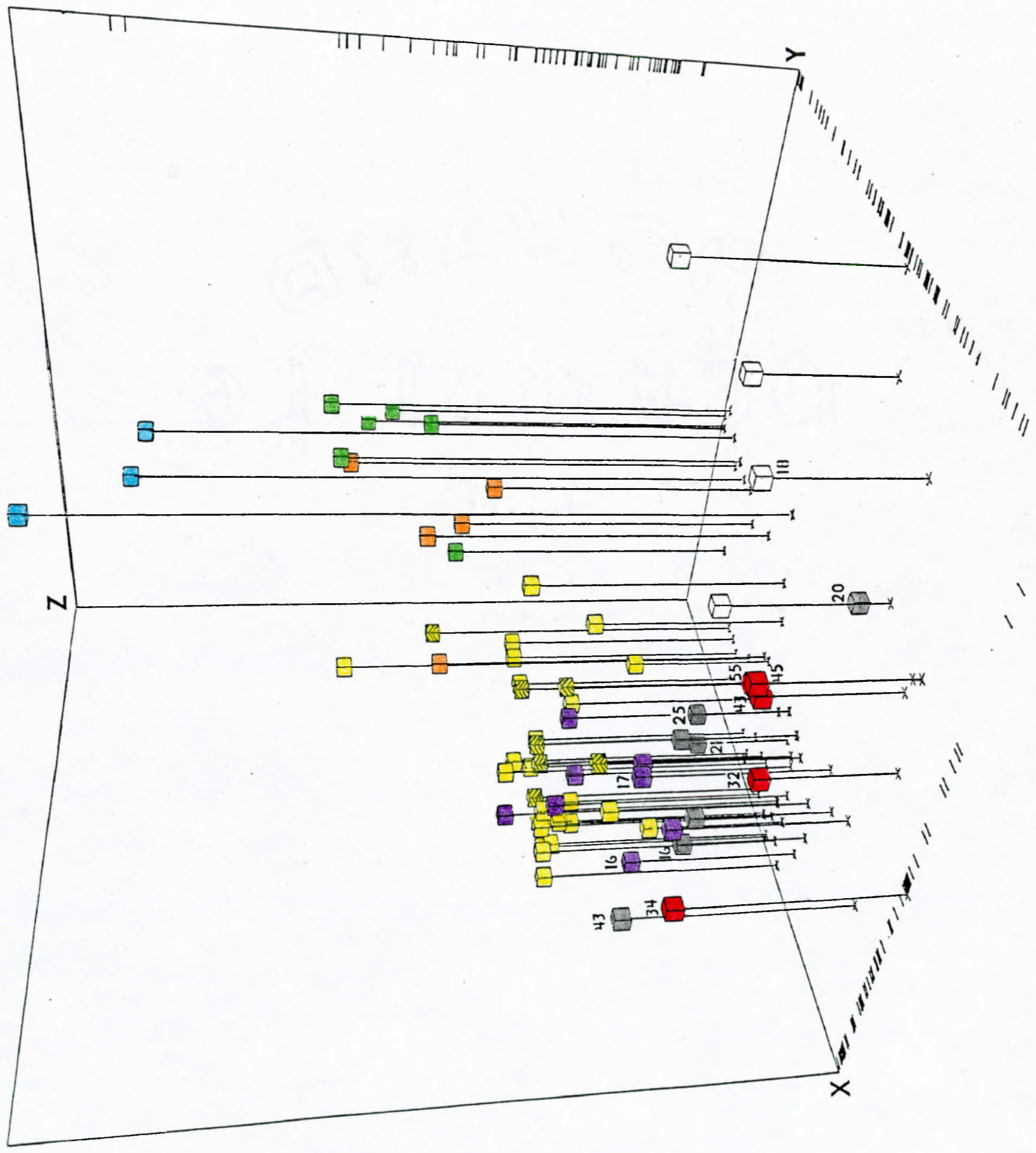

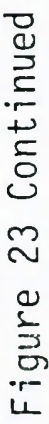


Correlation analysis

In order to determine the relationship between environmental measurements, a correlation analysis was run to test the relatedness of each variable with respect to all the other variables. The results are presented in Table 4. For all correlations, only those significant at the .05 and .01 levels are recorded.

Elevation was found to be positively correlated with moisture (at the .01 level) and negatively correlated with $\mathrm{pH}$ (.01 level), species diversity (.05 level), calcium (.05 level), and magnesium (.01 leve1). Positive correlations (a11 at the .01 level) were discovered between zinc, nitrate nitrogen, manganese, and soluble salt concentrations. The presence of organic matter in the soil was also positively correlated (at the .01 level) with the minerals zinc, and nitrate nitrogen. In addition, both calcium and magnesium positively correlated (at the .01 level) with $\mathrm{pH}$ and steepness of slope and with each other.

The remainder of the correlation analysis involved a) determining the relatedness between stand axes positions and the environmental variables, the results of which are presented with their respective ordinations, (Figs. 14, 16, and 24), and b) determining the relatedness of each species' importance to that of the other species (Tables 6 and 16, and Appendix B, Tables 25 and 26), and to the environmental parameters (Tables 5 and 16 and Appendix B, Tables 24 and 26). It must be remembered, however, that the results of correlation analyses only suggest factors which may influence the distribution of vegetation, since correlations only measure the degree of relatedness exhibited by the two sets of variables being compared, and cannot demonstrate any cause and effect relationships. 
52.
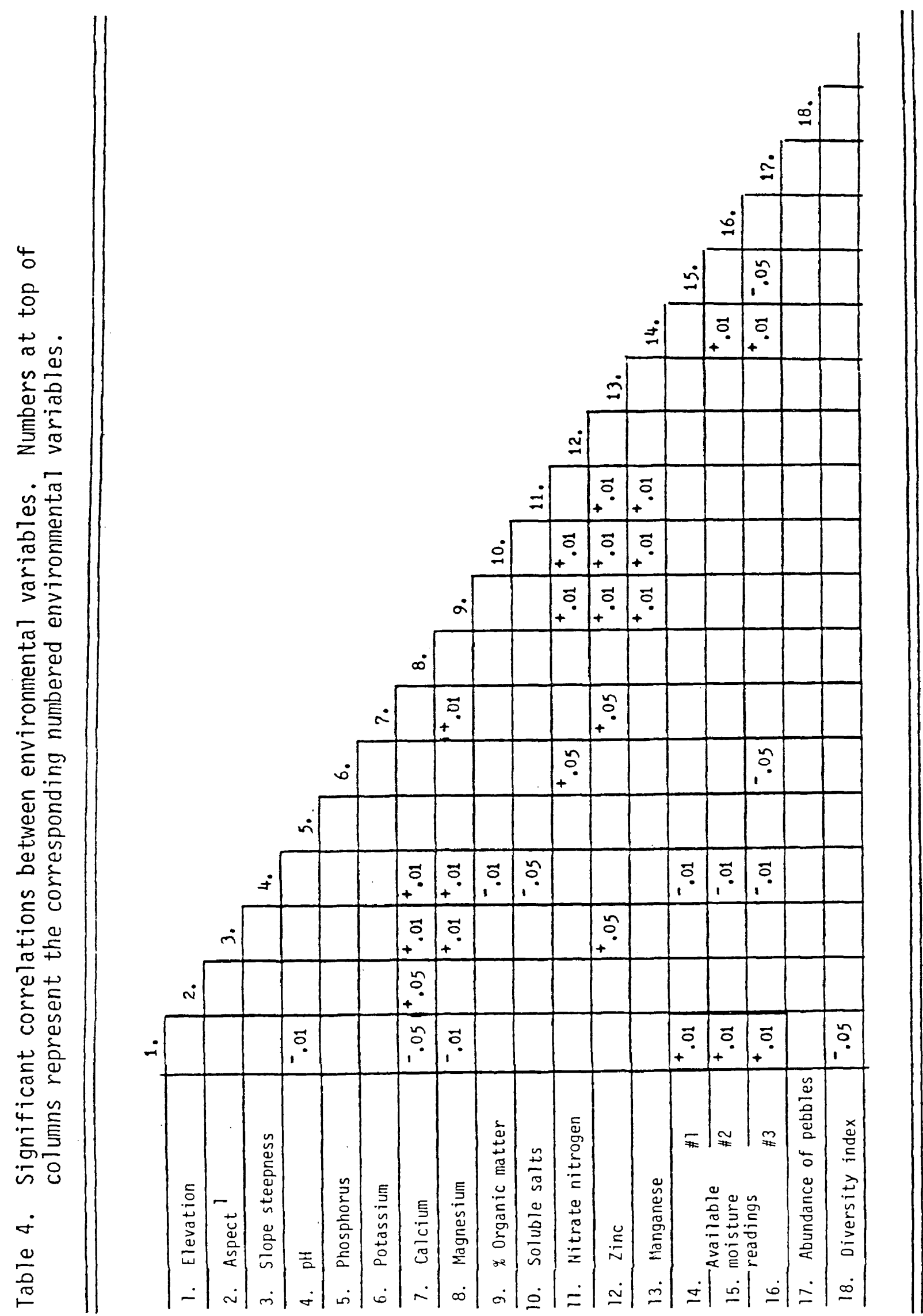

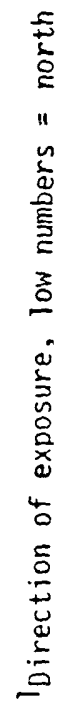


Table 5. Significant correlations between major woody species and environmental variables. Size class references: 1 = cancpy individuals, 2 = saplings, $3=1$ arger seedlings, $4=$ small seedlings. Correlations for class 1 derived from relative dominance values; those of all other classes derived from relative density values. Abbreviations for environmental variables: elev = elevation, asp = slope aspect, deg $=$ steepness of slope, $\mathrm{pH}=\mathrm{pH}$, phos $=$ phosphorus, $\mathrm{K}^{+}=$potas sium, $\mathrm{Ca}^{+}=$calcium, $\mathrm{Mg}^{+}=$magnesium, $\% 0 \mathrm{M}=\%$ organic matter, $\mathrm{SS}=$ Soluble salt level, $\mathrm{N}-\mathrm{N}=$ nitrate nitrogen, $\mathrm{Zn}=$ zinc, $M n$ = manganese, $M \# 1, M \# 2, M \# 3$ = available moisture readings, pebbles = abundance of pebbles, $H^{\prime}=$ species diversity (Shannon-Weaver formula). Abies and Picea dominance correlations based on the ten boreal coniferous forest stands only.

\begin{tabular}{|c|c|c|c|c|c|c|c|c|c|c|c|c|c|c|c|c|c|c|c|}
\hline Species & $\begin{array}{l}\text { size } \\
\text { Class }\end{array}$ & Leiey & asp & deg & $\mathrm{pH}$ & Lhos & $\mathrm{k}^{+}$ & $\mathrm{Ca}^{+}$ & $\mathrm{Mg}^{+}$ & go:1 & ss & $\mathrm{N}-\mathrm{N}$ & $2 n$ & $M n$ & $|m \neq 1|$ & M*2 & $\mid$ MA3 & $1 e^{e^{00^{5}}}$ & $H^{*}$ \\
\hline \multirow{4}{*}{$\begin{array}{l}\text { Abies } \\
\text { fraseri }\end{array}$} & 1 & +.01 & & & & & & & & & +.05 & +.05 & +.05 & & & & & & \\
\hline & 2 & 4.01 & & & & & & & & & & & & & & & & & \\
\hline & 3 & +.01 & & & & & & & & & & & & & & & & & -.05 \\
\hline & 4 & & & & & & ${ }^{4} .01$ & & & & & & & & & -.01 & -.01 & & \\
\hline \multirow{4}{*}{$\begin{array}{l}\text { Acer } \\
\text { saccharum }\end{array}$} & 1 & & & & & & & & & & & & & & & & & & \\
\hline & 2 & & & & & & & & & & & & & & & & & & \\
\hline & 3 & & & & & & & +.01 & +.05 & & & & & & & & & & \\
\hline & 4 & & & & & & & & & & & & & & & & & & \\
\hline \multirow{4}{*}{$\begin{array}{l}\text { Betula } \\
\text { lutea }\end{array}$} & 1 & +.01 & & & -.05 & & & & & & & & & & & & & & \\
\hline & 2 & & & $\because .05$ & -.05 & & & & & & +.02 & & & & & & & -.05 & \\
\hline & 3 & & & & & & & & & & & & & & & & & & \\
\hline & 4 & & & & & & & & & & & & & ${ }^{4} .05$ & & & & & \\
\hline \multirow{4}{*}{$\begin{array}{l}\text { Fagus } \\
\text { grandifolia }\end{array}$} & 1 & +.01 & & +.01 & -.05 & & & & & & & & & & & & & +.01 & -.01 \\
\hline & 2 & & & & & +.05 & +.05 & & & & & & & & & & & +.01 & \\
\hline & 3 & & & & & & & & & & & & & & & & & +.05 & \\
\hline & 4 & & & & & & & & & & & & & & & & & & \\
\hline \multirow{4}{*}{$\begin{array}{l}\text { Picea. } \\
\text { rubens }\end{array}$} & 1 & & & & & & -.05 & & & & & & & \begin{tabular}{|l|}
-.05 \\
\end{tabular} & & & & 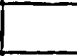 & -.05 \\
\hline & 2 & $\begin{array}{r}+.05 \\
\end{array}$ & & & & & & & & & & & & & & & & -.05 & -.01 \\
\hline & 3 & $\begin{array}{r}+.01 \\
\end{array}$ & & & & & & & & & & & & & & & & -.05 & -.01 \\
\hline & 4 & & & & & & & & & & & & & & & & & & -.01 \\
\hline \multirow{4}{*}{$\begin{array}{l}\text { Quercus } \\
\text { rubra }\end{array}$} & 1 & -.01 & & & +.01 & & & & & & & & & -.05 & & & -.05 & & +.05 \\
\hline & 2 & & & & +.01 & & & & & & & & & & -.05 & & -.01 & & \\
\hline & 3 & & & & & & & & & & & & & & & & & & \\
\hline & 4 & & & & & & & & & & & & & & & & & & \\
\hline \multirow{4}{*}{$\begin{array}{l}\text { Tilia } \\
\text { heteroohylla }\end{array}$} & 1 & $\begin{array}{r}.01 \\
\end{array}$ & & & & & & \begin{tabular}{|l}
.01 \\
\end{tabular} & .01 & & & & & & & & & & +.05 \\
\hline & $i$ & & & & & & & .01 & +.01 & & & & & & & 1 & & & +.05 \\
\hline & 3 & & & & & & & +.01 & .61 & & & & & & $i$ & I & & & \\
\hline & 4 & & & & & $1+.01$ & & & & & & & & 1 & 1 & $L$ & & & $i$ \\
\hline
\end{tabular}


Table 6. Significant correlations among major woody species. All correlations were derived from relative dominance values and are positive unless denoted by a "-". Correlations of Abies and Picea were derived solely from the 10 boreal coniferous forest stands; all other species' correlations were derived from the remaining 56 hardwood stands above $1150 \mathrm{~m}$ in elevation.

\begin{tabular}{|c|c|c|}
\hline & $<.05$ Level & $<.01$ Leve] \\
\hline Abies fraseri & & Sorbus americana \\
\hline Acer saccharum & $(-)$ Betula lutea & \\
\hline Betula lutea & $\begin{array}{l}\text { (-) Acer saccharum } \\
\text { Picea rubens }\end{array}$ & Acer spicatum \\
\hline Fagus grandifolia & $\begin{array}{l}\text { (-) Carya ovalis } \\
(-) \text { Fraxinum americana } \\
\text { (-) Magnolia acuminata } \\
\text { (-) Quercus prinus }\end{array}$ & $\begin{array}{l}(-) \text { Acer rubrum } \\
(-) \text { Quercus rubra }\end{array}$ \\
\hline Picea rubens & (-) Aesculus octandra & \\
\hline Tilia heterophylla & & $\begin{array}{l}\text { Fraxinus americana } \\
\text { Magnolia acuminata }\end{array}$ \\
\hline Quercus rubra & & $\begin{array}{l}\text { Acer rubrum } \\
\text { Carya ovata } \\
\text { Carya ovalis } \\
\text { Magnolia acuminata } \\
\text { Quercus alba } \\
\text { Quercus prinus } \\
\text { Robinia pseudo-acacia } \\
(-) \text { Fagus grandifolia }\end{array}$ \\
\hline
\end{tabular}


Woody vegetation

The composition of the canopy vegetation in the Balsam Mountains varies in a fairly predictable pattern, and with the aid of the polar ordination, could be differentiated into eight community-types (Figs. 14-17), which are discussed more thoroughly later in this section.

The ordination axes of the canopy data (from relative dominance values) show significant correlations with various measured environmental parameters. The $X$ axis of the polar ordination (Figs. 14 and 15) shows a negative correlation with elevation (at the .01 1evel), with the highest elevation stands located on the lower end of this axis. Other factors, such as magnesium, calcium, $\mathrm{pH}$, and species' diversity indices (a11 of which correlate positively with the $X$ axis at the .01 level) appear to correlate with the $x$ axis because of their negative correlative relationship with elevation (Table 4). Likewise, the $Z$ axis (Fig.14) appears to separate the stands according to elevation, since elevation correlates positively with this axis at the .01 level of significance. Negative correlations between this axis and species diversity indices and $\mathrm{pH}$ (at the .01 leve1), further suggests that separation along the $Z$ axis is associated with elevation (Table 4).

Although the $Y$ axis (Figs, 14 and 15) also correlates negatively with elevation at the .01 level, two other variables, manganese and soluble salt concentration (which positively correlate with one another at the .01 level, Table 4), show negative correlations with this axis at the .01 and .05 levels, respectively. Neither of these two parameters show any significant correlations with elevation. In addition, the other variables (moisture, calcium, magnesium, pH, and species diversity indices) associated with elevation in Table 4 do not 
correlate significantly with this axis.

The results of a correlation analysis between the most widespread or dominant woody species inhabiting the Balsams (Abies fraseri, Picea rubens, Acer saccharum, Fagus grandifolia, Quercus rubra, Betula lutea, and Tilia heterophylla) are summarized in Tables 5 and 6 . Relative dominance values for canopy species and relative density values for species occupying the smaller size classes were used in this analysis. Relative dominance values of each of the above species were also plotted separately on the three axes of the polar ordination (Figs. 18-23)

Woody vegetation ranges from a northern red oak - chestnut oak forest located on a dry southeast running ridge to a moist spruce-fir forest on the summit of Mount Rogers. The eight community-types occurring in the Balsam Mountains are described below along with those factors which seem influential in affecting their structure. However, it should be recognized throughout this discussion of community-types that communities are a function of their constituent species, and that the member species are themselves distributed individualistically (Curtis and McIntosh, 1951; Whittaker, 1956), and are not irrevocably associated with other members of the community. Furthermore, boundaries between community-types are not usually distinct, for boundaries tend to overlap, forming transition zones intermediate in vegetational composition. However, in several instances in the Balsams, community-types interdigitate with another and actual boundaries are clearly evidenced at a sharp ecotone. 
1. Spruce-fir Communities

The summit of Mount Rogers (stand Y, Figs. 6 and 14, and Table 7) is overwhelmingly dominated by Abies fraseri (Fraser fir), which comprises $78 \%$ of the canopy, with Picea rubens (red spruce) and Sorbus americana (mountain ash) exhibiting lesser importance. This communitytype is depicted in blue on the polar ordinations (Figs. 14 and 18). Fir reproduction is prolific in spruce-fir stands, with the greatest density of stems occurring in the small seedling category (less than $.5 \mathrm{~m}$ high). However, mortality is high or reproduction cyclic, since relatively few individuals appear in the sapling category. Ribes rotundifolium and Leucothoe recurva are relatively sparse in the shrub layer. The herbaceous composition of the summit consists almost entirely of 0 xal is acetose $11 \mathrm{a}$ (70\% coverage) and Dryopteris campyloptera ${ }^{1}$ (12\% coverage). Bryophytic coverage is also extremety high under the herbaceous layers, but no quantitative measurements were attempted.

Thick organic mats of live and decomposing vegetation occur over most of the summit area and seem to absorb and retaina great deal of moisture. Consequently, available soil moisture is high and measurements throughout the summer indicated a range of 96.5 to $99 \%$ moisture availability. Soil pH is low (3.3) in the spruce-fir zone, a condition commonly associated with subalpine forests.

The conifers near the summit are relatively small in stature in relation to those inhabiting the lower slopes. The high winds and low temperatures typically occurring on the summit must severely affect

1 Dryopteris campyloptera is the most abundant and widespread species inhabiting the Balsams. However, D. spinulosa and D. intermedia occur there as well and often hybridize among themselves, as well as with D. campyloptera, making identification difficult. Therefore, all three species of this complex genus are herein treated as D. campyloptera. 
Table 7. Spruce-fir community. Relative dominance values for canopy species and importance values for herbaceous species are recorded. An "X" refers to the presence of shrub species in the understory (see Table 19 for density values) and the presence of herbaceous species seen in the stand, but not actually encountered in a sample plot.

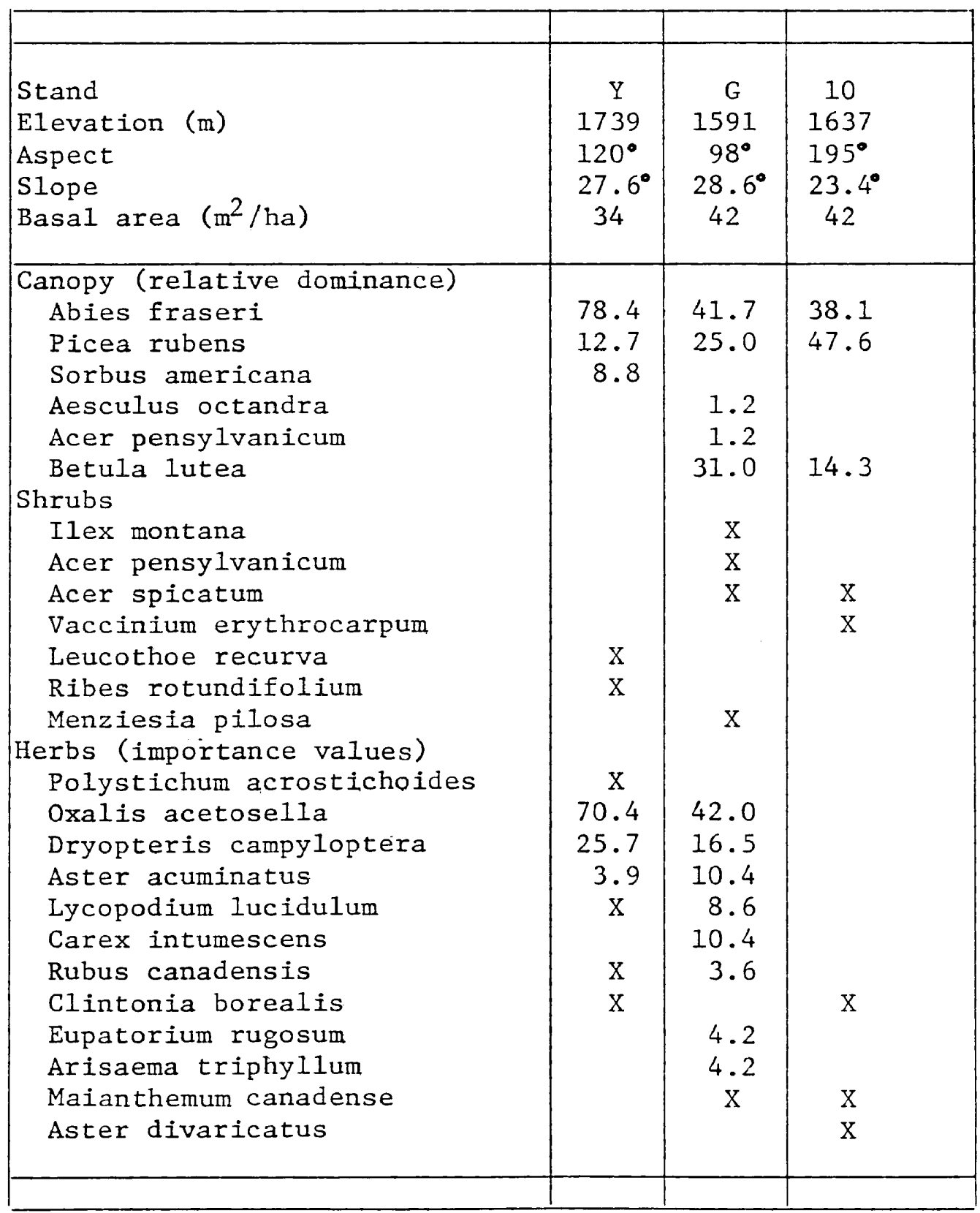


growth conditions. A ring count made of a $35 \mathrm{~cm}$ diameter spruce indicated that it had aged over 129 years before being uprooted by wind. In fact, downed timber of canopy-sized individuals is common on the summit. Windfall thus appears to be an important phenomenon affecting the summit vegetation.

Below the summit, fir decreases in importance while spruce and Betula lutea (yellow birch) become relatively more important (stands G and 10, Fig. 6 and Table 7). Fir is still abundantly represented in the smaller size classes, but unlike on the summit where most of the fir stems are concentrated in the lager seedling category (stems less than $.5 \mathrm{~m}$ high, Appendix A, Table 19), below the summit most of the firs occur in the larger seedling category (stems .5 to $1.5 \mathrm{~m}$ high). Spruce saplings(stems less than $10 \mathrm{~cm} \mathrm{dbh}$, but greater than $1.5 \mathrm{~m}$ high) at these elevations are also extremely dense, with over 800 individuals/ha (stand $G$ and Appendix A, Table 19). These 1arger seedlings of fir and spruce saplings often form dense stands of even-aged individuals. These almost pure pole stands may be advantageous in inhibiting the windfall (Brown, 1941) so common on the summit. In fact, personal observations indicate that windfall is a much more widespread phenomenon in the upper elevations.

Herbaceous coverage in sub-summit spruce-fir stands consists primarily of 0xalis acetosella and Dryopteris campyloptera, but Aster divaricatus, Carex intumescens, and Lycopodium lucidulum are also important.

At lower elevations, spruce and fir gradually decline in importance with fir dropping out much earlier than does spruce. Occasionally, spruce remains important far down the slope, particularly along flats and as a constituent in ravines to as $10 \mathrm{w}$ as $1280 \mathrm{~m}$ (stands $\mathrm{E}$ and 52 , Fig.10 and Table 9). With the decline of spruce and fir in the lower 
elevations, other species such as Betula lutea, Aesculus octandra, Acer saccharum, and Fagus grandifolia increase in importance. Sometimes, however, the spruce-fir community ends more abruptly, as exemplified by stands G (63\% conifer, Table 7$)$ and $H(71 \%$ hardwoods, Table 11$)$ which are separated by more than a $50 \mathrm{~m}$ transition zone (Fig. 6). Generally, the spruce-fir community is restricted to elevations above $1500 \mathrm{~m}$ on the north and south, and above $1625 \mathrm{~m}$ on the northwest, west, and southwest exposures (Shields, 1962 and personal observations). Fir also extends along the crest of adjacent Pine Mountain (Fig. 6) to Cabin Ridge, but the vegetation there is currently being disturbed by grazing cattle.

Spruce-fir stands tend to have high $Z$ values and low $X$ values on the polar ordination (Fig. 14). High $Z$ values correspond to high elevations and low pH and magnesium levels, low species diversity, and a low abundance of pebbles in the soil, while low $X$ values correspond to high elevations, and low pH, species diversity, and calcium and magnesium levels. The relative dominance (cross sectional area breast high) of fir is depicted in parentheses on the ordination in Fig. 18. A correlation analysis of the 10 high elevation boreal forest communities shows that increased fir dominance is associated with higher elevations (at the .01 level). Levels of nitrate nitrogen and zinc also correlate positively with fir dominance (.05 Tevel); however, both of these minerals also correlate positively with each other (at the .01 level, Table 4).

Surprisingly, small seedling densities of fir correlate negatively with soil moisture (Table 5). There are a number of possible explanations for this result: 1) the soil at the highest elevations (near the 
summit is more moist and fir reproduction there is lower, and 2) most sampling of the boreal coniferous forest stands was done on the south and west sides of Mount Rogers (where conditions are presumably drier) because of the steep, boulder strewn aspect of the north slope. Densities of larger seedlings also show a negative correlation (.05 level) with species diversity in this size class. This may be because seedlings often form dense pole stands. Finally, high densities of small seedlings show an unexpected positive correlation (at the .01 level) with high phosphorus levels.

\section{Spruce Communities}

Fraser fir is absent from Whitetop Mountain and so only spruce forests occur at the highest elevations (Figs. 4, 5, and 14 and Table 8). Spruce always dominates the canopy in spruce communities, but it is often associated with various amounts of Betula lutea (yellow birch), Amelanchier laevis (serviceberry), Acer saccharum (sugar maple), and Fagus grandifoilia (American beech). Spruce dominanted stands are depicted in blue on the polar ordination (Figs. 14 and 18).

Acer pensylvanicum and Vaccinium erythrocarpum are the most important understory species, but Viburnum alnifolium commonly occurs in the understory as wel1. Herbaceous vegetation consists primarily of the ferns Dryopteris campyloptera and Thelypteris noveboracensis along with the herbs Clintonia boreal is, Rubus canadensis, oxalis acetosella, and Maianthemum canadense, although not all of these species occur together in every area.

Spruce forests are generally restricted to elevations above $1580 \mathrm{~m}$ on Whitetop, but extend tongue-like down rocky ridges where pockets of organic matter tend to collect, and along gradual slopes or flats to 
Table 8. Spruce community. Relative dominance values for canopy species and importance values for herbaceous species are recorded. An " $\mathrm{X}$ " refers to the presence of shrub species in the understory (see Table 19 for density values) and the presence of herbaceous species seen in the stand, but not actually encountered in a sample plot.

\begin{tabular}{|c|c|c|c|c|c|c|}
\hline $\begin{array}{l}\text { Stand } \\
\text { Elevation (m) } \\
\text { Aspect } \\
\text { Slope } \\
\text { Basal area }\left(\mathrm{m}^{2} / \mathrm{ha}\right)\end{array}$ & $\begin{array}{c}34 \\
1439 \\
265^{\circ} \\
14.4^{\circ} \\
44\end{array}$ & $\begin{array}{c}29 \\
1475 \\
200^{\circ} \\
7.2^{\circ} \\
50\end{array}$ & $\begin{array}{c}18 \\
1463 \\
0^{\circ} \\
0^{\circ} \\
32\end{array}$ & $\begin{array}{l}31 \\
1554 \\
75^{\circ} \\
39.6^{\circ} \\
42\end{array}$ & $\begin{array}{c}\text { L } \\
160^{\circ} \\
153^{\circ} \\
12^{\circ} \\
34\end{array}$ & $\begin{array}{l}30 \\
1481 \\
115^{\circ} \\
10.5^{\circ} \\
33\end{array}$ \\
\hline $\begin{array}{l}\text { Canopy (relative dominance) } \\
\text { Picea rubens } \\
\text { Betula lutea } \\
\text { Acer spicatum } \\
\text { Amelanchier laevis } \\
\text { Acer saccharum } \\
\text { Prunus serotina } \\
\text { Fagus grandifolia } \\
\text { Acer rubrum } \\
\text { Shrubs } \\
\text { Hamamelis virginiana } \\
\text { Acer pensylvanicum } \\
\text { Ilex montana } \\
\text { Sorbus americana } \\
\text { Acer spicatum } \\
\text { Sambucus pubens } \\
\text { Vaccinium erythrocarpum } \\
\text { Viburnum alnifolium } \\
\text { Herbs (importance values) } \\
\text { Trillium erectum } \\
\text { Osmunda cinnamomea } \\
\text { Dryopteris campyloptera } \\
\text { Oxalis acetosella } \\
\text { Aster acuminatus } \\
\text { Polysodium virginicum } \\
\text { Lycopodium lucidulum } \\
\text { Clintonia borealis } \\
\text { Rubus canadensis } \\
\text { Thelypteris noveboracensis } \\
\text { Maianthemum canadense } \\
\text { Carex pensylvanicum } \\
\text { Carex intumescens } \\
\text { Arisaema triphyllum } \\
\text { Viola spp. }\end{array}$ & $\begin{array}{l}X \\
X \\
X \\
X \\
X \\
X \\
X \\
X \\
X \\
X\end{array}$ & $\begin{array}{l}X \\
X \\
X \\
X \\
X\end{array}$ & $\begin{array}{r}73.5 \\
8.2 \\
16.3 \\
2.0\end{array}$ & $\begin{array}{r}76.2 \\
14.3 \\
9.5\end{array}$ & $\begin{array}{r}13.4 \\
15.9 \\
14.4 \\
4.2 \\
4.2\end{array}$ & $\begin{array}{r}45.5 \\
21.2 \\
9.1 \\
21.2 \\
3.0\end{array}$ \\
\hline & & & & & & \\
\hline
\end{tabular}


much lower elevations. As was found in the spruce-fir forests on Mount Rogers, the soil of spruce communities also contain a high concentration of organic matter (11\%), a high moisture availability (96.5 to 99\%), and low pH values (3.7) (Appendix A, Table 22).

An extensive spruce flat (stands 18 and 34 , Fig. 5 and Table 8), which can be easily viewed from Mount Rogers, extends down to at least $1400 \mathrm{~m}$ on the southeast side of Whitetop. It is composed almost entirely of spruce $(91 \%)$ in the canopy. Its transition with hardwoods on each side is relatively abrupt, particularly along it western border where it is separated from a beech-maple stand (stand 35) at Whitetop Creek. The line of demarcation is Whitetop Creek and very few spruces occur on the western side of the stream. Disturbance (ie. the selective removal of spruce) initially seemed to be a reasonable explanation, particularly since Rubus canadensis is exceptionally dense and the overgrown remains of what appeared to be an old logging road were discovered. However, U.S. Forest Service records indicate that no selective removal of spruce ever occurred in this area. Consequently, in the absence of known human disturbance, only a sharp difference in past or present environmental conditions on either side of the creek could be resposible for such a widely differing vegetational composition.

Stands with spruce as a dominant also occur on Mount Rogers, but there, wherever it is a dominant, fir is also important, and by the time fir drops out in the lower elevations, spruce is no longer a dominant. Therefore, pure spruce forests (je. communities in which spruce dominates and fir is absent) occur only on Whitetop.

Correlation analysis of the 10 boreal coniferous forest stands (on both Whitetop and Mount Rogers) show that high canopy dominance of spruce 
correlates with decreased manganese and potassium concentrations (at the .05 level, Table 5). High spruce dominance is also inversely correlated with Aesculus octandra (sweet buckeye) dominance at the .05 level. When correlation analyses were done separately on hardwood dominated stands above $1150 \mathrm{~m}$, spruce dominance correlated with high fir and mountain ash dominance (both at the .01 level) and high Magnolia fraseri (Fraser magnolia) and yellow birch dominance (at the .05 level, Table 6). Again, as was found for the higher elevation conifer forests, increased spruce dominance shows a negative correlation (at the .01 level) with the abundance of pebbles in the soil, for spruce is usualiy associated with soils of high organic content even in the lower elevations. This negative correlation between spruce and pebbly soil was foundeven in the larger and small seedling categories (at the .05 level).

\section{Yellow Birch Communities}

Betula lutea (yellow birch), although most important on high elevation north slope boulder fields and in deep ravines, is probably the most widespresd species in the Balsam Mountains. This species is generally considered to be seral in the southern Blue Ridge, although it is present in low densities in climax forests (Daubenmire, 1978:104).

Yellow birch dominated communities are depicted in orange on the polar ordination (Fig. 14) with the relative dominance values (based on cross sectional area breast high) of yellow birch in each stand recorded on the ordination in Fig. 19.

Almost pure stands of yellow birch occur on the most rugged high elevation boulder fields (stand 54, Fig. 3 and Table 9). Under less 
Table 9. Yellow birch community. Relative dominance values for canopy species and importance values for herbaceous species are recorded. An "S" refers to the presence of shrub species in the understory (see Table 19 for density values) and the presence of herbaceous species seen in the stand, but not actually encountered in a sample plot.

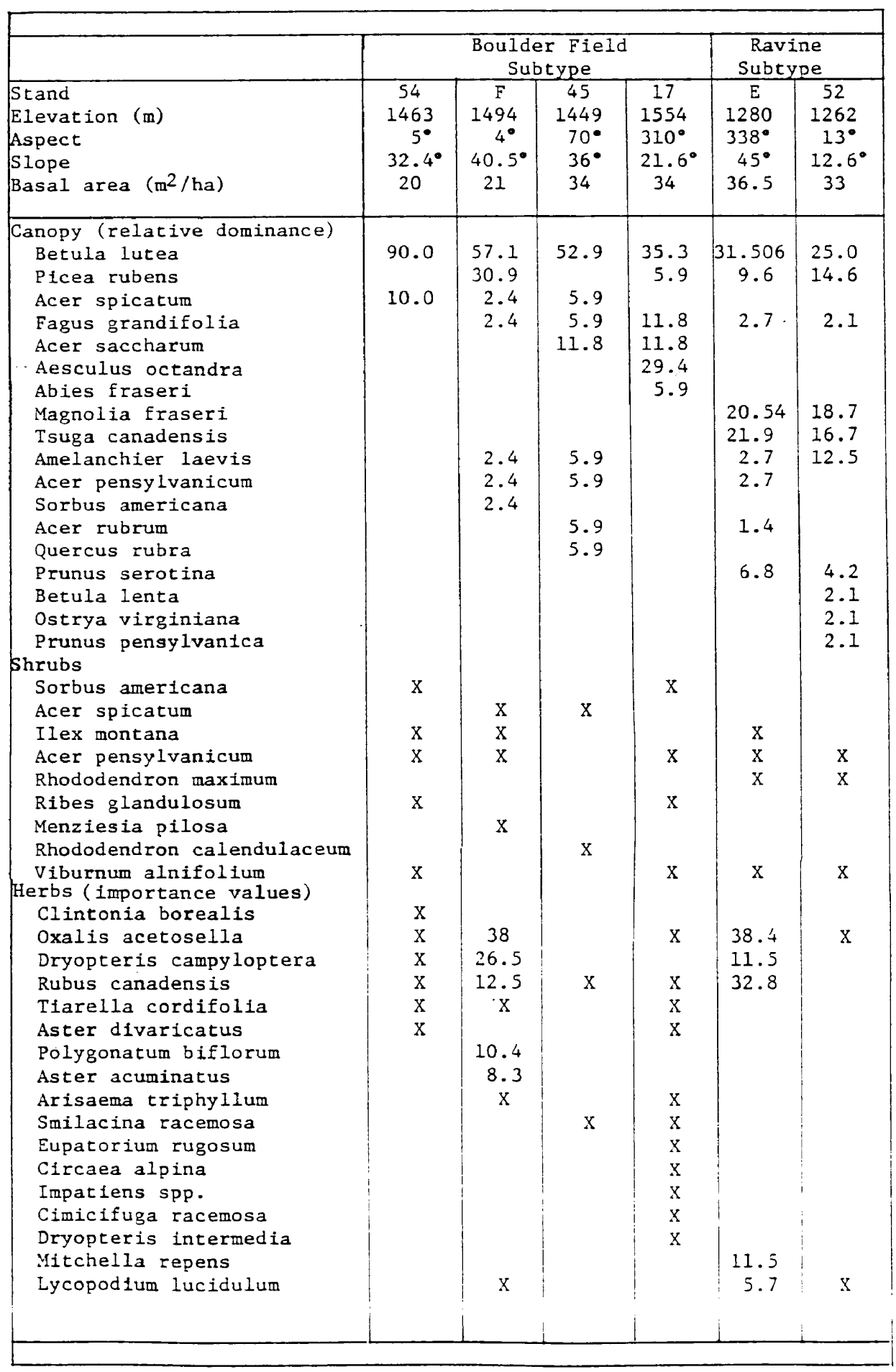


66.

extreme conditions, yellow birch's associates may be spruce, sweet buckeye, sugar maple, or beech (stands F, 17, and 45, Figs. 5 and 6 , and Table 9). Acer pensylvanicum is often the dominant understory species, but Acer spicatum, Ilex montana, and Ribes glandulosum are prevalent. The herbaceous stratum is composed predominantly of 0xal is acetosella, Dryopteris campyloptera, Rubus canadensis, and Polygonatum biflorum.

Communities of deep ravines differ from those on boulder fields in that yellow birch is associated with different codominants such as Magnolia fraseri, Tsuga canadensis, and Picea. Here Rhododendron maximum and Acer pensylvanicum are the only important understory species. The most abundant herbaceous species are oxalis acetosella and Rubus canadensis, but total herb coverage is relatively low, particularly in areas subjected to periodic flooding. This 'ravine subytpe' occurs along Lewis Fork ravine (stands E and 52, Fig. 7, and Table 9).

Correlation results (Tables 5 and 6 ) show that yellow birch is more important at higher elevations (at the .01 level) and where pH levels are low (.01 level). High yellow birch dominance also correlates positively with high Acer spicatum and Picea dominance (both at the .05 level) and negatively with high Acer saccharum dominance (at the .01 leve1).

Sapling densities are also higher in areas of low $\mathrm{pH}$, high soluble salt concentrations, and steeper slopes (a11 at the .05 level). Note however, that none of the smaller size classes correlate significantly with elevation. This suggests that the smaller size classes are widespread at all elevations, but that dominance is maintained only on high elevation boulder fields or in areas of excessive organic matter buildup as in Lewis Fork ravine. 


\section{Northern Hardwoods Community}

Northern harwoods generally dominate the zone avove $1350 \mathrm{~m}$ and below the boreal coniferous forests. In the absence of a boreal coniferous forest zone on some peaks, northern hardwoods extend al1 the way to the summit. This communitycan be divided into two subtypes distinguished on the basis of general physiognomy and herbaceous composition. One is here referred to as the dwarf orchard subtype and the other as the beech-maple subtype. The northern hardwoods community-type is depicted in yellow on the ordination (Figs. 14, 20, and 21) with the dwarf orchard subtype represented by hatched blocks.

Dwarf orchard forests (Table 10) occur on and just below high elevation exposed summits above $1400 \mathrm{~m}$ (stands 15, 24, 25, and 55, Figs 3 and 4), and adjacent to balds (stands 11, 19, and 20, Figs. 3, 4, and 6). Most stands are composed predominantly of beech, with varying amounts of yellow birch. Sugar maple and sweet buckeye are rare subdominants in dwarf orchards. The subtype is recognized by the noticeably stunted aspect of beech and buckeye. With the exception of scattered yellow birches and sugar maples, few stems are greater than $6 \mathrm{~m}$ in height and $40 \mathrm{~cm}$ in diameter. Stems in smaller size classes are relatively sparse, thus giving the forest an open, orchard-1ike aspect, though the canopy is usually continuous.

Typical understory species are Acer pensylvanicum, Acer spicatum, Ribes glandulosum, Sambucus pubens, and Ilex montana. Herbaceous coverage is high and characteristic species include Dryopteris campyloptera, Aster divaricatus, Rubus canadensis, Oxal is acetosella, and Eupatorium rugosum. Dwarf orchards of similar vegetational composition are common throughout the higher elevations of the southern Blue Ridge (Davis, 1930; Cain, 1931; Braun, 1950; Whittaker, 1956). 
Table 10. Northern hardwoods community (dwarf orchard subtype). Relative dominance values for canopy species and importance values for herbaceous species are recorded. An " $X$ " refers to the presence of shrub species in the understory (see Table 19 for density values) and the presence of herbaceous species seen in the stand, but not actually encountered in a sample plot.

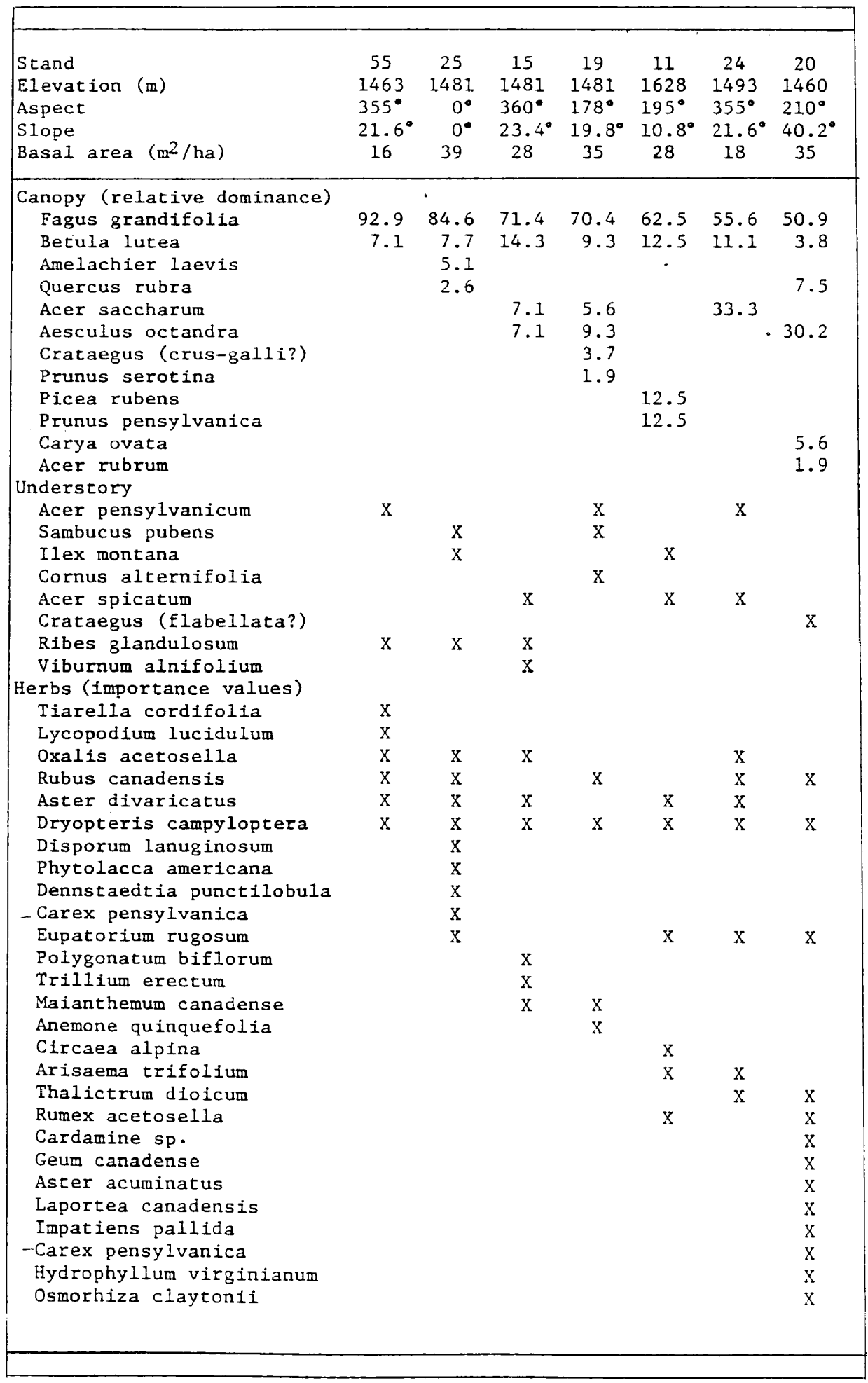


The beech-maple subtype community (Table 11) occurs on more sheitered slopes, where the environment is presumably less severe, and more closely resembles lower elevational forests in general physical appearance. Stem density in the smaller size classes is usually higher than in the dwarf orchards and so the aspect is generally one of less openess.

Beech is the leading dominant in most of the stands, but occasionally sugar maple dominates. When sugar maple is the dominant, beech is usually important also, but not all beech dominated stands contain an appreciable coverage of sugar maple. Yellow birch is often a codominant in beech and beech-maple stands. In stands located near the boreal forest zone, spruce is likely to appear as a subdominant as well (stand H, Fig. 6). Most of the understory species occurring in the dwarf orchards occur also in the beech-maple subtype community, but often Viburnum alnifolium shows greater coverage in the latter. Likewise, the same herbaceous species are common in both forest subtypes; however, additional species such as Aster acuminatus, Maianthemum canadense, Impatiens spp. ${ }^{2}$. Athyrium asplenioides, and Thelypteris noveboracensis are occasionally important.

Grasses (Festuca obtusa, Poa cuspidata, Brachyelytrum erectum, and Cinna latifolia) and sedges (Carex pensylvanica, C. intumescens, $\underline{\text { C. }}$ debilis, and $\underline{C}$ aestivalis) occur throughout the beech-maple subtype, but are particularily abundant on south slopes (stands $P$ and 32 , Fig. 5). For instance, in a south-facing stand on Whitetop Mountain (stand P), Carex pensylvanica showed $100 \%$ coverage in some plots, al though Rubus

${ }^{2}$ Includes mostly $\underline{I}$. pallida, although some $\underline{I}$. capensis may also be present. 
Table 11. Northern hardwoods community (beech-maple subtype). Relative dominance values for canopy species and importance values for herbaceous species are recorded. An " $X$ " refers to the presence of shrub species in the understory (see Table 19 for density values) and the presence of herbaceous species seen in the stand, but not actually encountered in a sample plot.

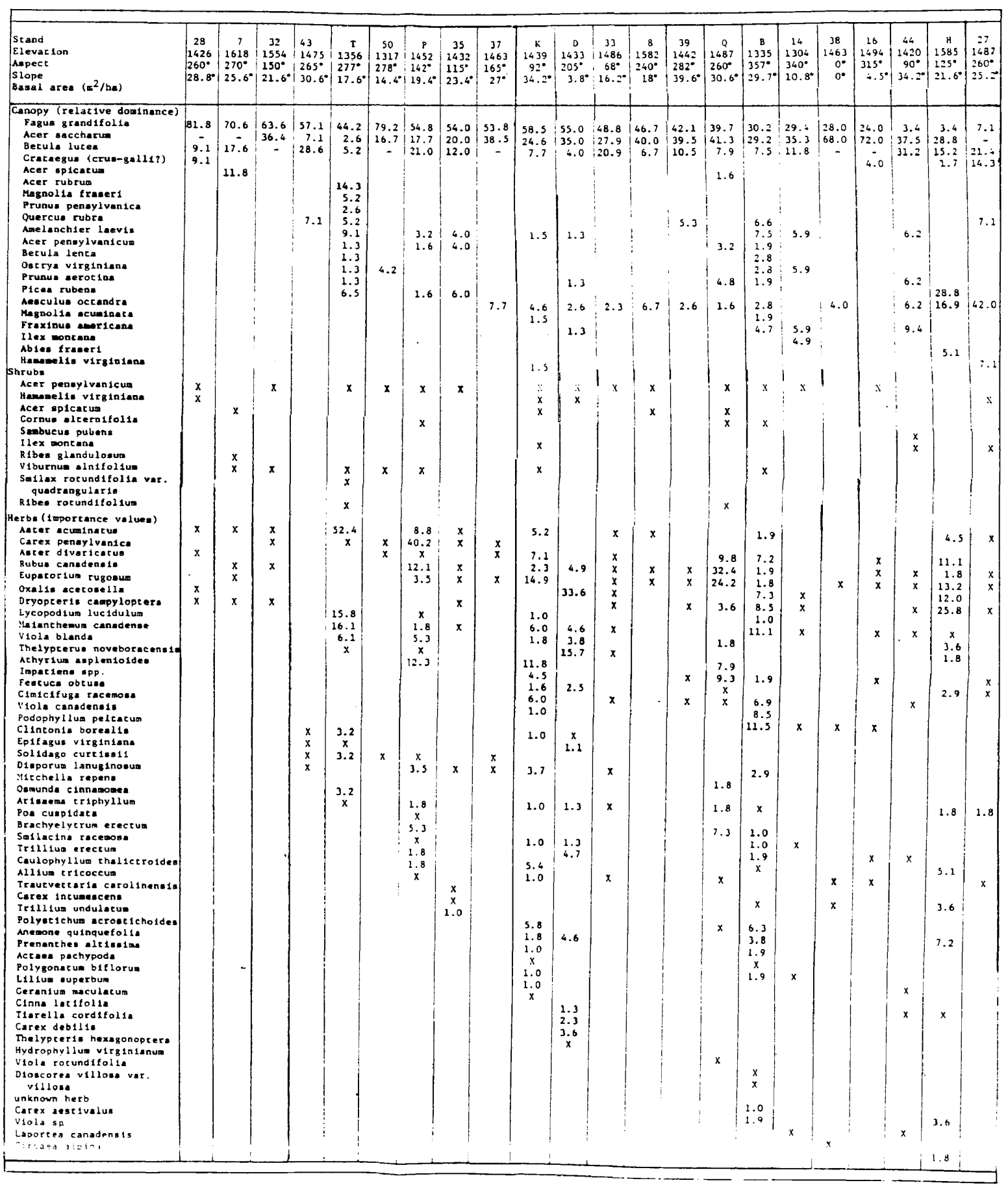


canadensis and Athyrium asplenioides are also important in this stand. These south-facing beech-maple woods, like the dwarf orchards, are rather open or park-7ike in appearance, but differ from the orchards in that the trees are larger in stature, and in that the herbaceous layer is more varied in composition.

A11 northern hardwoods stands are concentrated midwayalong the $X$ and $Z$ axes (Fig. 14), but have relatively low $Y$ values, which axis, as indicated previously, correlates negatively with elevation, manganese, soluble salt levels, and moisture. Relative dominance values (cross sectional area breast high) of the two most important northern hardwoods species, beech and sugar maple, are presented on the polar ordination in Figs. 20 and 21 respectively. Their separate correlations with environmental and biological factors are summarized below.

Sugar maple appears to be a widespread occurring species in the Balsams, although it attains its highest coverages in the northern hardwoods communities. Sugar maple is the only major canopy species which failed to show a significant correlation with any of the environmental parameters. However, it did show a negative correlation with yellow birch, thus suggesting that it may be limited to more physiographically or successionally mature areas where yellow birch is less prevalent.

Two races of beech (Camp, 1951), the red and the gray (or dwarf beech), inhabit the Balsams and usually dominate the northern hardwoods zone. Since no soil samples or moisture readings were taken from the dwarf orchards (gray beech) forests, mineral and moisture correlations refer to the red race only. Since beech is prevalent throughout most of the higher elevations (beech is correlated positively with 
elevation at the .01 leve1), most of the significant correlations correspond to high elevations. For example, beech shows a negative correlation with $\mathrm{pH}$ and species diversity (both at the .01 level), which themselves correlate negatively with elevation (Table 4). In addition, the abundance of beech in the canopy shows negative correlations with a number of lower elevation species (Table 6) such as Acer rubrum, (at the .01 level) and Fraxinus americana (.05 leve1) and also negative correlations with more xeric species such as Quercus prinus and Carya ovalis (both at the .05 level). Beech also appears to be more important on rockier substrates (ie. soils with more pebbles), since all three of the largest size classes correlate with high pebble adundance (Table 14).

\section{High Elevation Mixed Mesophytic Communities}

The mixed mesophytic forests of high elevations are the most variable and diverse community-type in the Balsam Mountains. This communitytype is designated 'high elevation' because it occurs at a higher elevation than the typical mixed mesophytic forests of the Cumberlands (Braun, 1950) and the mesophytic cove forests of the Great Smokies (Braun, 1950; Whittaker, 1956) and so lacks the lower elevation canopy constituents such as Liriodendron tulipifera, Isuga canadensis, Quercus alba, Nyssa sylvatica, Juglans nigra, and Carya spp. However, like the typical lower elevation mixed mesophytic forests, various combinations of mesic species dominate the canopy: Ti7ia heterophyl1a, Acer saccharum, Fagus grandifolia, Fraxinus americana, Betula lutea, Aesculus octandra, Quercus rubra, and Acer rubrum. The mixed mesophytic community-type is depicted in purple on the canopy ordination (Figs. 14 and 22). 
High elevation mixed mesophytic communities occur on all but the south and southwest exposures (Table 12). but are best developed on the north slope of Mount Rogers (stands A, 1, 2, and 5, Fig. 6 and Table 12). The north slope of Whitetop Mountain also harbors mixed mesophytic communities, but they are less well developed there since that particular aspect is predominantly composed of fairly sharp leads rather than open slopes (stands 12 and 13, Fig. 4). Regardless of aspect or extent of development, these mixed mesophytic forests tend to have Tilia heterophylla (white basswood) and/or Fraxinus americana (white ash) as important canopy constituents. Also, ericeceous shrubs, indicators of drier conditions, are absent from mixed mesophytic stands. Instead, understory species such as Acer pensylvanicum and Cornus florida are predominant. Root sprouts of Castanea dentata (American chestnut) are present in slightly less mesic sites (note stand 0, Fig. 3 and Table 9).

Other diagnostic features of high elevation mixed mesophytic forest communities are the richness and luxuriance of their herbaceous strata, which is extremely well developed, often showing greater than $100 \%$ coverage. Typical dominants include Arisaema triphyl7um, Laportea canadensis, Impatiens spp., Hydrophyllum virginiana, Trillium erectum, Osmorhiza claytonii, Viola spp. (especially V. canadensis and V. blanda), Polygonatum biflorum, Cimicifuga racemosa, Galium triflorum, Caulophyllum thalctroides, Eupatorium rugosum, Podophyllum peltatum, and Polystichum acrostichoides. Often, over 25 species can be identified in any one stand. Mixed mesophytic communities are so consistently luxuriant and rich in species that they consitute the most varied community-type in the Balsam Mountains.

Above $1350 \mathrm{~m}$, beech and sugar maple become increasingly important 
Table 12. Mixed-mesophytic community. Relative dominance values for canopy species and importance values for herbaceous species are recorded. An " $X$ " refers to the presence of shrub species in the understory (see Table 19 for density values) and the presence of herbaceous species seen in the stand, but not actually encountered in a sample plot.

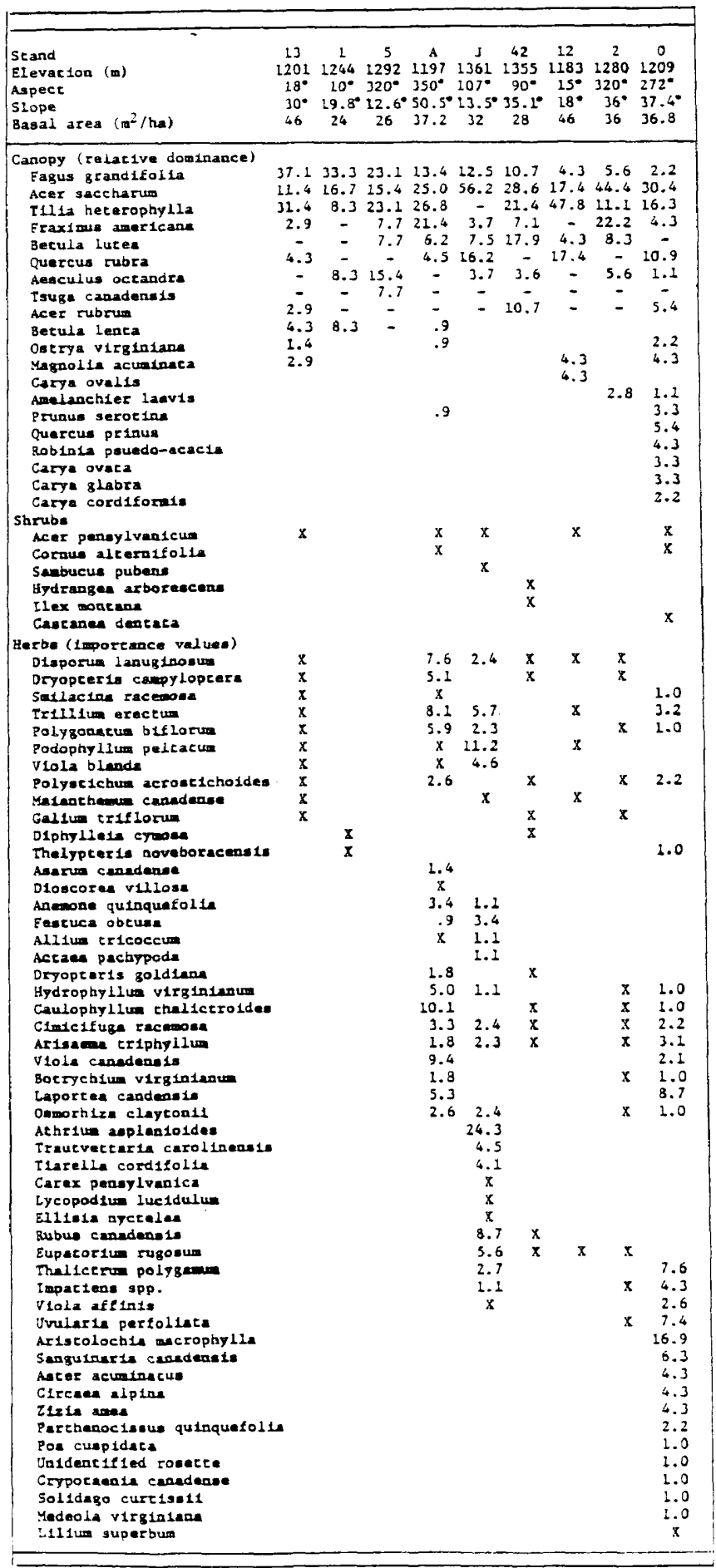


as the canopy composition trends toward the northern hardwoods type. Understory composition changes much more slowly during the transition to northern hardwoods and thus many of the lower elevation species are common in the higher elevations as wel1. Often, however, Rubus canadensis shows increased coverage at the higher elevations.

White basswood is concentrated in the mixed mesophytic stands, and was previously mentioned as being indicative (along with white ash) of this community-type. The relative dominance values (cross sectional area breast high) of basswood for each stand in which basswood is important are shown on the ordination in Fig. 22.

Correlation analyses (Table 5) show that the three largest sizeclasses of basswood correlate positively with calcium and magnesium levels (at the .01 level), and that high basswood dominance is correlated positively with high $\mathrm{pH}$ values (at the .05 level). Both calcium and magnesium levels correlate with one another and with elevation (all at the .01 leve1, Table 4). However, basswood dominance does not correlate with elevation. It is interesting to note that high ash dominance also strongly correlates with high calcium and magnesium concentrations (at the .01 Tevel, Appendix B, Table 24) and high basswood dominance (at the .01 level, Appendix B, Table 25), especially since both of these species were noted to be indicative of the mixed mesophytic community-type in the Balsams.

\section{Northern Red Oak Communities}

Communities dominated by Quercus rubra (northern red oak) are generally found on east, west, and south facing slopes between 1150 and $1350 \mathrm{~m}$ in elevation (Table 13). This community-type is depicted 
Table 13. Northern red oak community. Relative dominance values for canopy species and importance values for herbaceous species are recorded. An " $X$ " refers to the presence of shrub species in the understory (see Table 19 for density values) and the presence of herbaceous species seen in the stand, but not actually encountered in a sample plot.

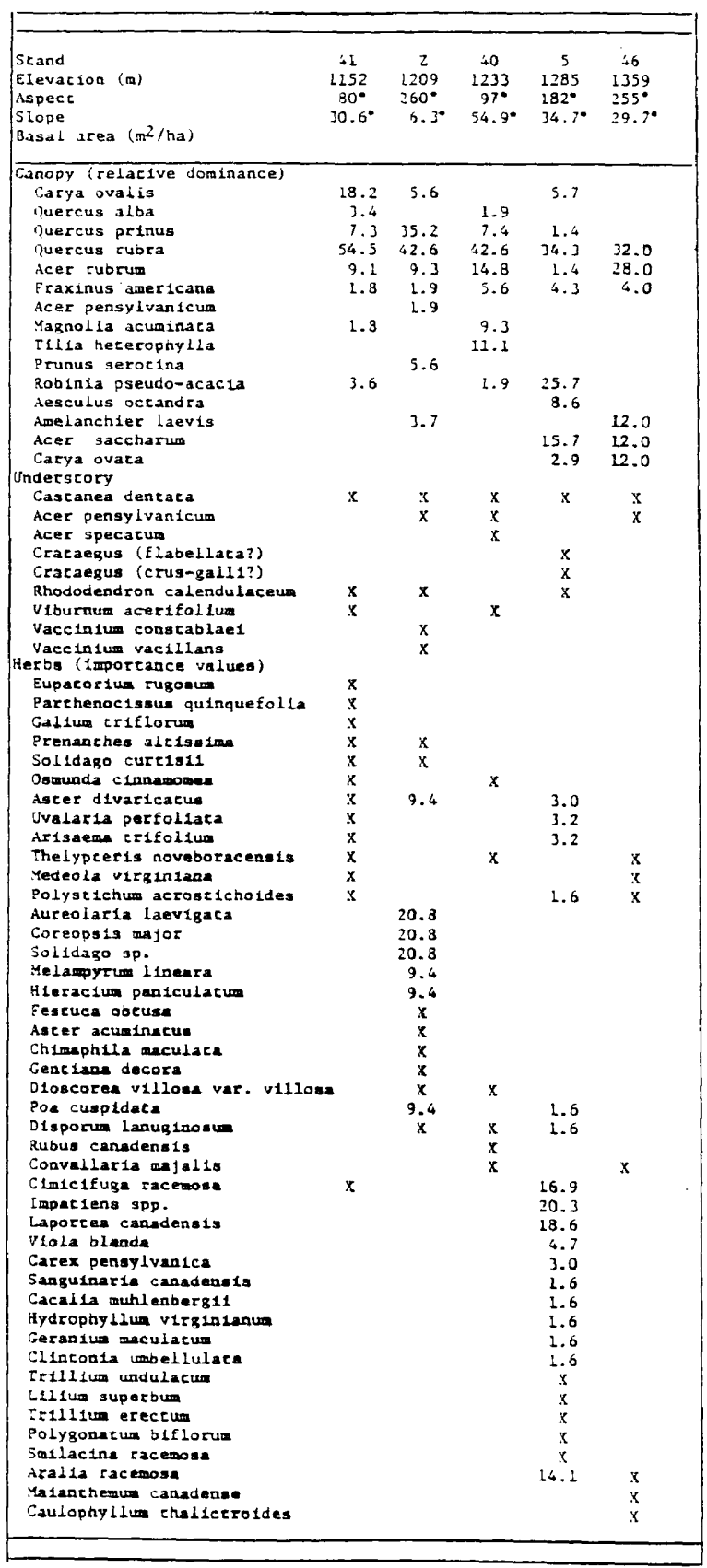


in red on the polar ordination (Figs. 14 and 23). Acer rubrum (red maple) is invariably present in this community-type and is often an important constituent of the canopy. Other canopy species occurring in significant amounts include Quercus prinus (chestnut oak) and Carya ovalis (sweet pignut hickory) and, under presumably more mesic conditions, sugar maple and basswood. A17 northern red oak stands have evidence that chestnut had once been a member of the community, albeit in varying degrees of importance. These stands would no doubt have been treated as red oakchestnut forests by Whittaker (1956).

In a northern red oak community located atop a southeast running ridge (stand Z, Fig. 8 and Table 13), dominated by northern red oak and chestnut oak, clear signs of past chestnut dominance abound. Many of the fallen, bleached, and twisted trunks remain, along with numerous root sprouts in the understory. Other understory species include Acer pensylvanicum, and ericads 1 ike Rhododendron calendulaceum, Vaccinium constablaei, and Vaccinium vacillans. Herbaceous vegetation is sparse in this stand; four out of five plots were devoid of herbaceous vegetation altogether, and the one vegetated plot had only a $55 \%$ coverage. The most important species occurring in the plot that contained herbaceous vegetation were Coreopsis major, Solidago patula, and Aureolaria laevigata. As anticipated, available soil moisture was low in this stand, ranging from 20 to $54 \%$ (Appendix $A$, Table 22). In fact, this stand had the lowest recorded available moisture readings of any stand in the study. This ridge stand is the extreme xeric condition encountered in the Balsam Mountains, where communities more mesic in composition are far more characteristic of open slopes. In more mesic northern red oak communities [submesic according to Whittaker's (1956) classification], 
sugar maple, basswood, and buckeye may be subdominant to northern red oak. In these forests (Table 13), the understory is relatively sparse, but often contains Acer pensylvanicum, Rhododendron calendulaceum, Viburnum alnifolium, and chestnut root sprouts. However, it is the composition of the herbaceous stratum that suggests the relatively mesic nature of most of the northern red oak communities of the Balsam Mountains. For example, a sampled south-facing stand (stand S, Fig. 5) contains an appreciable coverage of Impatiens spp., Laportea canadensis, Cimicifuga racemosa, and Smilacina racemosa. The other listed stands also contain additional mesics such as Disporum lanuginosum, Thelypteris noveboracensis, Polystichum acrostichoides, and Aster divaricatus. Available soil moisture in stand S ranged from 53 to 90\% (Appendix A, Tab7e 22) - much higher than that measured in the more xeric ridge stand discussed previous7y.

Toward higher elevations (ie. above $1300 \mathrm{~m}$ ), the canopy composition begins to reflect the transition to northern hardwoods. Beech, sugar maple, and yellow birch, species commonty associated with the northern hardwoods community-type, tend to increase in importance, while red maple and sweet pignut hickory decrease in importance (note stand S again, above).

The relative dominance (cross sectional area breast high) of northern red oak for each stand in which this species is important is recorded on the polar ordination in Fig. 23. The correlation analysis shows that northern red oak dominance is higher in the lower elevations, in relatively higher $\mathrm{pH}$ soils (both at the .05 level, Table 5). The relationship with manganese would not have been discerned if the stands had not been split into high and low elevation categories prior to the correlation analysis. Therefore, only with respect to the lower elevation stands 
does northern red oak dominance correlate with manganese.

High northern red oak dominance also correlates positively with

other lower elevation submesic species such as Acer rubrum, Carya ovalis,

Carya ovata, Magnolia acuminata, Quercus alba, Quercus prinus, and Robinia pseudo-acacia, but correlates negatively with high beech dominance (a11 at the .01 leve1, Table 6). None of the lower elevation species with which northern red oak shows significant correlations (above), show any significant correlations with manganese levels.

\section{Mesophytic-oak Communities}

On less mesic south and west slopes, one encounters vegetation intermediate in composition between that of the mixed mesophytic and the northern red oak forests. (Table 14). This community-type is depicted in gray on the canopy ordination (Fig. 14). Mesic and submesic species such as beech, sugar maple, yellow birch, and occasionally red maple and sweet buckeye are important on these slopes, but the characteristic mixed mesophytic species, basswood (entirely absent) and ash (rare) are unimportant. Further, northern red oak tends to exhibit much greater dominance in these stands (where dominance ranges from 0 to $17 \%$, Table 12 ). This combination of dominants suggests that these stands are submesic in character.

Common understory species include Acer pensylvanicum and Cornus alternifolia, with the ericads Vaccinium corymbosum and V. erythrocarpum present under less mesic conditions. The herbaceous vegetation consists primarily of Aster acuminatus, Maianthemum canadense, Arisaema triphy 17 um, and Dryopteris campyloptera. In fact, Maianthemum frequently attains its greatest coverages (stands $N$ and V, Fig. 7) in mesophytic-oak stands. 
Table 14. Mesophytic-oak community. Relative dominance values for canopy species and importance values for herbaceous species are recorded. An "X" refers to the presence of shrub species in the understory (see Table 19 for density values) and the presence of herbaceous species seen in the stand, but no actually encountered in a sample plot.

\begin{tabular}{|c|c|c|c|c|c|c|c|}
\hline $\begin{array}{l}\text { Stand } \\
\text { Elevation }(w) \\
\text { Aspect } \\
\text { Slope } \\
\text { Basal area }\left(m^{2} / h a\right)\end{array}$ & $\begin{array}{c}51 \\
1338 \\
263^{\circ} \\
14,4^{-} \\
34^{\circ}\end{array}$ & $\begin{array}{c}26 \\
1487 \\
190^{\circ} \\
21.6^{\circ} \\
28\end{array}$ & $\begin{array}{l}21 \\
1336 \\
280^{\circ} \\
31.2^{\circ} \\
30^{\circ}\end{array}$ & $\begin{array}{c}N \\
1234 \\
301^{\circ} \\
33.7^{\circ} \\
38\end{array}$ & $\begin{array}{c}47 \\
1432 \\
193^{\circ} \\
7^{\circ} \\
31\end{array}$ & $\begin{array}{l}9 \\
1426 \\
205^{\circ} \\
38.6^{\circ} \\
27\end{array}$ & $\begin{array}{l}7 \\
1356 \\
350^{\circ} \\
32.4^{\circ} \\
27.5\end{array}$ \\
\hline \multicolumn{8}{|l|}{ Canopy (relative dominance) } \\
\hline Fagus grandifolia & 46 & 32 & 18 & 16 & 19 & - & - \\
\hline Quercus rubra & 21 & 25 & 13 & 20 & 16 & 43 & 18 \\
\hline Acer saccharum & 2 & - & 20 & 2 & 39 & 28 & 47 \\
\hline Secula lutea & 8 & 18 & 20 & 1 & 3 & 4 & 5 \\
\hline Amelanchier laevis & 6 & 4 & 2 & 19 & - & - & 4 \\
\hline Acet rubrum & 8 & 11 & 16 & 8 & 6 & - & 5 \\
\hline Aesculus octandra & - & 4 & 7 & - & - & 17 & \\
\hline Picea rubens & 2 & $=$ & - & & - & - & - \\
\hline Prunus serotina & 6 & 7 & $=$ & - & 3 & - & - \\
\hline Prunus pensylvanica & & & 2 & - & - & $=$ & $=$ \\
\hline Fraxinus americana & & & 2 & - & - & 2 & 4 \\
\hline Betula lenta & & & & 11 & - & - & 9 \\
\hline Magnolfa Eraser 1 & & & & 9 & & & \\
\hline Quercus prinus & & & & 7 & & & \\
\hline Magnol fa acuatinata & & & & $\mathbf{s}$ & & & \\
\hline Robiala pseudo-acacia & & & & 1 & & & \\
\hline Acer pensylvanicum & & & & & & - & 7 \\
\hline \multicolumn{8}{|l|}{ Shrubs } \\
\hline $\begin{array}{l}\text { Acer pensylvanicum } \\
\text { Cralaegus crus-gall1 }\end{array}$ & $x$ & $x$ & $\begin{array}{l}x \\
x\end{array}$ & 8 & & $x$ & x \\
\hline $\begin{array}{l}\text { Crataegus crus-gall1 } \\
\text { Cornis alteraifol1a }\end{array}$ & & & $\begin{array}{l}x \\
x\end{array}$ & & $\frac{x}{x}$ & & \\
\hline Castanea dercata & & & $\mathbf{x}$ & & & $x$ & $x$ \\
\hline Hanawel is virginiana & & & & $\mathrm{x}$ & & & \\
\hline Sambucus pubens & & & & & I & & \\
\hline Acer splcatum & & & & & $\mathbf{x}$ & & \\
\hline Cracaegus (Ilabellata?) & & & & & & & $x$ \\
\hline Vaccinium erychrocarpun & & $x$ & & & & & \\
\hline Vaccintum corymbosum & & & & $x$ & & & \\
\hline Menziesia pllosa & & & & $\mathbf{x}$ & & & \\
\hline Piburnum alnifolium & & & $x$ & & & & \\
\hline $\begin{array}{l}\text { Sallax rotundifolla var. } \\
\text { quadrangularis }\end{array}$ & & & & $x$ & & & \\
\hline $\begin{array}{l}\text { Ribes rotuadifolia } \\
\text { Herbs (1 mportance valueg) }\end{array}$ & & & & & & & $\mathbf{x}$ \\
\hline Thelypteris noveboracensis & $\mathrm{x}$ & & $\mathrm{x}$ & & & 2.9 & \\
\hline D1sporum Lang 1nosum & $\mathrm{x}$ & & & & & 3.1 & \\
\hline Aster acuminatus & $\mathrm{x}$ & $x$ & $\mathrm{x}$ & & & 11.8 & 3.9 \\
\hline Matanthemum canadense & $x$ & & $\mathbf{x}$ & & & 1.6 & 6.6 \\
\hline Carex pensylvanicz & $x$ & & & & & 13.5 & \\
\hline Eupatortum rugosud & & $x$ & $\mathrm{x}$ & & & & 9.2 \\
\hline Laportea canadelis Is & & $\mathbf{x}$ & $\mathbf{x}$ & & & & 3.9 \\
\hline Impectens spp. & & & $\mathbf{x}$ & & $x$ & & 29.8 \\
\hline Clmicifuge raceroosa & & & $x$ & & $\mathbf{x}$ & & 6.6 \\
\hline Polygonatum b fiorua & & & $\mathbf{x}$ & & & & \\
\hline Clintonla borealls & & & I & & & & \\
\hline Smllacina racemosa & & & $x$ & $x$ & $\mathbf{x}$ & & \\
\hline Trililum undulatua & & & $\mathbf{s}$ & 17.1 & & & $\mathbf{x}$ \\
\hline Lycopadiuta lucidulua & & & $\Sigma$ & 17.4 & & 1.6 & \\
\hline Medeola virginiana & & & $\mathbf{x}$ & 4.3 & & 1.6 & \\
\hline Dryopteris campyloptera & & & $\mathrm{x}$ & & & 32.7 & \\
\hline Thasplum barbinode & & & $x$ & & & 3.9 & \\
\hline Osmorhiza clayzon 11 & & & $x$ & 4.3 & & & 2.5 \\
\hline Dloscorea villosa & & & I & & & $x$ & 1.4 \\
\hline Eabenarle orblculaca & & & $x$ & & & & \\
\hline Convalleria majalls & & & & 8.5 & & 1.6 & \\
\hline Deningraede1s punctillobula & & & & 4.3 & & & \\
\hline Plola blanda & & & & 4.3 & & & \\
\hline Trillium erectum & & & & 6.3 & & & \\
\hline Carex zentivalis & & & & .2 & & & \\
\hline Clintonla umbelluiate & & & & .2 & & & \\
\hline Carex pensylvanica & & & & $x$ & & & \\
\hline Clane lat folla & & & & & $\mathbf{x}$ & & \\
\hline Gellue criflorus & & & & & $\mathbf{x}$ & & $x$ \\
\hline Rubus canadensis & & & & & $x$ & 3.1 & 5.7 \\
\hline Athyriun asplenioldes & & & & & & 6.9 & \\
\hline Ossunda cinnasomea & & & & & & 6.0 & \\
\hline Vlola rotunalfolla & & & & & & 3.1 & \\
\hline Lyoluchia quadrifolla & & & & & & 3.1 & \\
\hline Brachyelgerim exectum & & & & & & 2.9 & \\
\hline Prenentenes alelssia & & & & & & 1.6 & \\
\hline Anemole quilaquefolla & & & & & & 1.6 & \\
\hline Podophyliua peltacun & & & & & & 1.6 & \\
\hline Lycopod lua obacurita & & & & & & $x$ & \\
\hline Lillum superbua & & & & & & $\mathbf{x}$ & \\
\hline Hydrophyllus virginienum & & & & & & & 9.9 \\
\hline rescuca obtuse & & & & & & & 3.6 \\
\hline Caulophyllux thalle roldes & & & & & & & 4.3 \\
\hline Polyscichum acrost tcholdes & & & & & & & 2.3 \\
\hline Uvularia perfoilace & & & & & & & 1.4 \\
\hline Thalectrum polygasun & & & & & & & 1.4 \\
\hline Vlole afflats & & & & & & & 1.4 \\
\hline Gerentue mecularua & & & & & & & $x$ \\
\hline
\end{tabular}




\section{Lower Elevation Communities}

At the lowest elevations, below $1150 \mathrm{~m}$, most of the forests are in a disturbed condition (Table 15 and represented by white blocks on the polar ordination, Fig. 16). However, one relatively undisturbed stand (stand R) was located and sampled. This stand is dominated by $\underline{\text { Acer }}$ rubrum, Carya ovalis, Quercus prinus, and Quercus rubra, but 22 other woody species are present, fourteen of which are canopy species. Clear evidence of the past importance of chestnut is present as we11. Understory species include Rhododendron calendulaceum, Hamamel is virginiana, Castanea dentata sprouts, Acer pensylvanicum, Viburnum acerifolium, and Vaccinium vacillans. Smal1 amounts of Cornus florida and Vaccinium corymbosum are also present. In fact, this stand contains the greatest number of woody species encountered in the study and has the second highest diversity index (Appendix A, Table 23).

The herbaceous stratum is composed predominantly of the ferns Thelypteris noveboracensis and 0smunda cinnamomea (17\% and $11 \%$ coverage, respectively; Appendix A, Table 20). Twenty other herbaceous species were encountered fairly frequently in the sample plots, but none of them accounted for more than $2 \%$ of the total coverage.

In addition to the sampled stand $R$, several listings were also made in disturbed stands in the hope of projecting their future composition in the absence of further disturbance. Al1 of these stands (stands 36, 48, and 49) are located in the Lost Mountain area (see Fig. 3) where the prevailing topography is one of sharp ridges and deep draws. All three stands are dominated by Liriodendron tulipifera, a common successional species of the lower elevations, and each contains evidence of the past presence of chestnut. However, the stands differ with respect 
Table 15. Lower elevation community. Relative dominance values for canopy species and importance values for herbaceous species are recorded. An " $X$ " refers to the presence of shrub species in the understory (see Table 19 for density values) and the presence of herbaceous species seen in the stand, but not actually encountered in a sample plot.

\begin{tabular}{|c|c|c|c|c|}
\hline $\begin{array}{l}\text { Stand } \\
\text { Elevacion (m) } \\
\text { Aspect } \\
\text { Slope } \\
\text { Basal area }\left(m^{2} / \mathrm{ha}\right)\end{array}$ & $\begin{array}{c}\mathrm{R} \\
1128 \\
78.5^{\circ} \\
14^{\circ} \\
38.5\end{array}$ & $\begin{array}{c}36 \\
1012 \\
350^{\circ} \\
32.4^{\circ} \\
39^{\circ}\end{array}$ & $\begin{array}{c}48 \\
1055 \\
75^{\circ} \\
20.4^{\circ} \\
46\end{array}$ & $\begin{array}{c}49 \\
1009 \\
28^{\circ} \\
25.2^{\circ} \\
38\end{array}$ \\
\hline \multicolumn{5}{|l|}{ Canopy (relacive doninance) } \\
\hline Carya ovalis & 20.8 & - & - & - \\
\hline Acer rubtum & 28.6 & 20.7 & 4.5 & 7.9 \\
\hline Quercus prinus & 14.3 & 3.5 & 19.4 & 2.6 \\
\hline Quercus rubra & 13.0 & 6.9 & 17.9 & 2.6 \\
\hline Betula lenta & 2.6 & 6.9 & - & \\
\hline Listadendron culiplfera & - & 31.0 & 35.3 & 50.0 \\
\hline Betula lucea & 1.3 & 7.0 & - & 34.2 \\
\hline Carya ovaca & 6.5 & & & . \\
\hline Eraxinus americana & 3.9 & & & \\
\hline $\begin{array}{l}\text { Quercus alba } \\
\text { Yyssa syivatica }\end{array}$ & 1.3 & & & \\
\hline Hamamelis virginiana & $\begin{array}{l}1.3 \\
1.3\end{array}$ & 1.7 & & \\
\hline Magnol1a Erasert & & 6.9 & & \\
\hline Oxydendron arboreum & & 6.9 & & \\
\hline Sassafras albidum & & 3.4 & & \\
\hline Robin1a pseudo-acac1a & 1.3 & 3.4 & 6.0 & \\
\hline Magnol1a acuninata & 2.6 & & 4.5 & \\
\hline IIIla hecerophylla & 1.3 & & 3.0 & \\
\hline Cornus florida & & & 4.5 & \\
\hline Acer saccharum & & & 1.5 & \\
\hline Aesculus octandra & & & 1.5 & \\
\hline Eagus grandffolla & & 3.4 & 1.5 & 2.6 \\
\hline \multicolumn{5}{|l|}{ Shruba } \\
\hline Castanea dencaca & $x$ & $x$ & $\mathrm{x}$ & $\mathrm{x}$ \\
\hline deer pensylvantcum & $x$ & $x$ & $\mathrm{x}$ & $\mathrm{x}$ \\
\hline $\begin{array}{l}\text { Hamamel is virginiana } \\
\text { Cornus florida }\end{array}$ & $\begin{array}{l}x \\
x\end{array}$ & $\mathrm{x}$ & $x$ & \\
\hline $\begin{array}{l}\text { Cornus florida } \\
\text { Iiex montante }\end{array}$ & 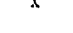 & $\mathrm{x}$ & $x$ & \\
\hline Rhododendron maximua & & & & $\mathrm{x}$ \\
\hline $\begin{array}{l}\text { Vaceinium corymbosum } \\
\text { Viburnum acertfollum }\end{array}$ & $\begin{array}{l}x \\
x\end{array}$ & & & \\
\hline Vaccintun vacillans & $\begin{array}{l}x \\
x\end{array}$ & & & \\
\hline $\begin{array}{l}\text { Rhododendron calendulaceum } \\
\text { Herbs (1mportance values) }\end{array}$ & $x$ & & & \\
\hline $\begin{array}{l}\text { Herbs (1mportance valises) } \\
\text { Osaunda cinnasoomea }\end{array}$ & 16.2 & & & \\
\hline Thelypceris noveboracensis & 23.0 & & $\mathrm{x}$ & \\
\hline Clmlcfiuge racemose & 5.9 & & $\ddot{x}$ & \\
\hline Solidego curtisail & 5.9 & & & \\
\hline Aeter divaricatus & 5.9 & & & \\
\hline Eupacorium maculatum & 4.4 & & & \\
\hline Thasplum barbinode & 3.3 & & & \\
\hline Pretidfum aquilidus & 3.3 & & & \\
\hline Prenanches aitissima & 2.9 & & & \\
\hline Z1z12 auren & 2.9 & & & \\
\hline Sangulnaria canadena1s & 2.9 & & & \\
\hline Viola affinis & 2.9 & & & \\
\hline Pedtcularis canadenels & 2.9 & & & \\
\hline Aster lacer1flarus & 1.5 & & & \\
\hline $\begin{array}{l}\text { Carex aestivalis } \\
\text { Pos cuspidaca }\end{array}$ & $\begin{array}{l}1.5 \\
1.5\end{array}$ & & & \\
\hline Goodyera pubescens & 1.5 & & & \\
\hline Uvularia perfollaca & 1.5 & & & \\
\hline Arlsaem trifollum & 1.5 & & & \\
\hline Naldsceinia fragartoldes & 1.5 & & & \\
\hline Galium eriflorum & 2.9 & $\mathrm{x}$ & & \\
\hline $\begin{array}{l}\text { Dryopteris campy loptera } \\
\text { Digporem lanug trosum }\end{array}$ & 1.5 & & $\mathrm{x}$ & \\
\hline $\begin{array}{l}\text { Disporum lanugtaosum } \\
\text { Oloscorea villosa var. }\end{array}$ & $\begin{array}{l}x \\
2.9\end{array}$ & & $\mathrm{x}$ & $\mathrm{x}$ \\
\hline $\begin{array}{l}\text { Villosa } \\
\text { Lyeopod1um obscurum }\end{array}$ & $x$ & & & $\mathrm{x}$ \\
\hline Polystichum acrose1choides & & $\mathrm{x}$ & & \\
\hline Thelypteris hexagonoptera & & & $x$ & \\
\hline Vlola spp. & & & $x$ & \\
\hline $\begin{array}{l}\text { Impatiens spp. } \\
\text { Smllacina racemosa }\end{array}$ & & $x$ & $\begin{array}{l}x \\
x\end{array}$ & $\mathrm{x}$ \\
\hline Sol1dego sp. & & & $\ddot{x}$ & $\hat{\mathrm{x}}$ \\
\hline Matanchemum canadense & & & & $\mathrm{x}$ \\
\hline
\end{tabular}


to their subdominant and seedling compositions. One stand (36) contains Acer rubrum as a subdominant, along with seedlings of quercus prinus, Tsuga canadensis, and Sassafras albidum. Another stand (49) harbors Betula lenta as a subdominant, along with seedlings of Fagus, Acer saccharum, Tilia, and Magnolia acuminata. The third stand (48) seems most similar to stand $R$ above; Quercus rubra and Quercus prinus are the subdominants, but Acer rubrum seedlings are abundant, along with Quercus rubra, Acer saccharum, Magnolia acuminata, Magnolia fraseri, and Castanea sprouts.

The hebaceous stratum is extemely sparse (undoubtably affected by disturbance), but is best developed in stand 48 where the ferns Dryopteris spp., The lypteris noveboracens is, The lypteris hexanonoptera, and Osmunda cinnamomea occur along with the herbs Impatiens spp., Aster acuminatus, Prenanthes altissima, Viola spp., Arisaema triphyllum, Cimicifuga racemosa, and Solidago spp.

It is difficult to generalize about the eventual composition (in the absence of disturbance) of the stands located in the Lost Mountain area with so little data available. The topography is so variable that a wide variety of community-types should be expected to develop, each influenced by the topography of the site, with most stands probably eventually being dominated by mesic and submesic species.

Herbaceous vegetation

The herbaceous vegetation of the Balsam Mountains is so variable that communities of similar woody vegetational structure often differ remarkably in herbaceous composition. Only one herbaceous community-type could be distinctly differentiated: the 0xalis acetosella - Dryopteris 
campy loptera community. This herb community is located predominantly in deep ravines, on high north slope boulder fields, and on summits in boreal coniferous forests, areas where the soils are moist and the concentration of decomposing organic matter is high. The herbaceous stratum in other areas is so variable in composition and in general luxuriance that other community-types are not separable.

The separation of the sampled stands on the polar ordination (Fig. 24) contributes further evidence in support of their variabilitv. The $Z$ (or vertical) axis effected the best separation of the stands on the ordination. This axis shows negative correlations (a11 at the .01 level) with $\mathrm{pH}$, calcium and magnesium levels, and species diversity, and a positive correlation (at the .01 level) with elevation. The X axis of the ordination correlates positively with species diversity (.05 leve1) and $\mathrm{pH}(.01$ level), and negatively with elevation (.01 level) and moisture (.05 leve1), while the $Y$ axis shows a positive correlation with the proportion of organic matter in the soil (.01 level) and a negative correlation with $\mathrm{pH}$ (at the .05 level).

The $Z$ axis of the herbaceous ordination separates these stands remarkably well. The correlation analysis suggests that this axis represents an elevation gradient, since elevation and five out of six parameters which correlate with elevation (Table 4) also correlate with the $Z$ axis. Four of the five stands dominated by 0xalis and Dryopteris (stands F, E, L, G, and Y; Figs. 4 and 6 and Tables 7-9), were the highest elevation stands sampled; all five have high $Z$ values. Only stand E (Fig. 6, Table 9) from Lewis Fork ravine occurs in the lower elevations. Though moisture does not correlate with the $Z$ axis, the soils of all these five stands have high levels of moisture (Appendix 
85.

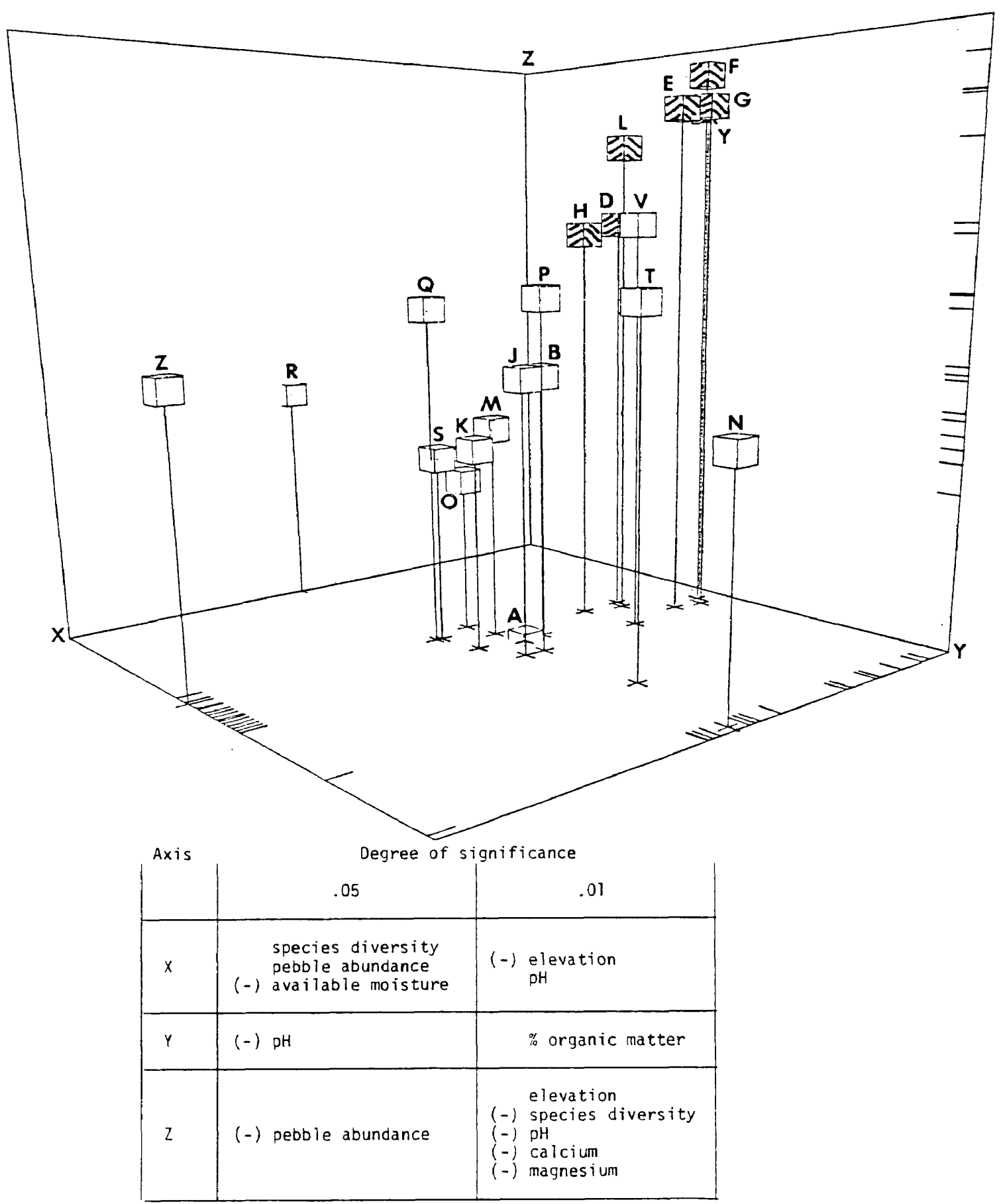

Figure 24. A polar ordination of sampled stands derived from herbaceous species importance values (above). The origin of the axes is located in the back corner. Hatched blocks represent Oxalis-Dryopteris communities. Below, significant correlations between each of the three ordination axes and the measured environmental parameters; al1 correlations are positive unless denoted by a "-". 
86.

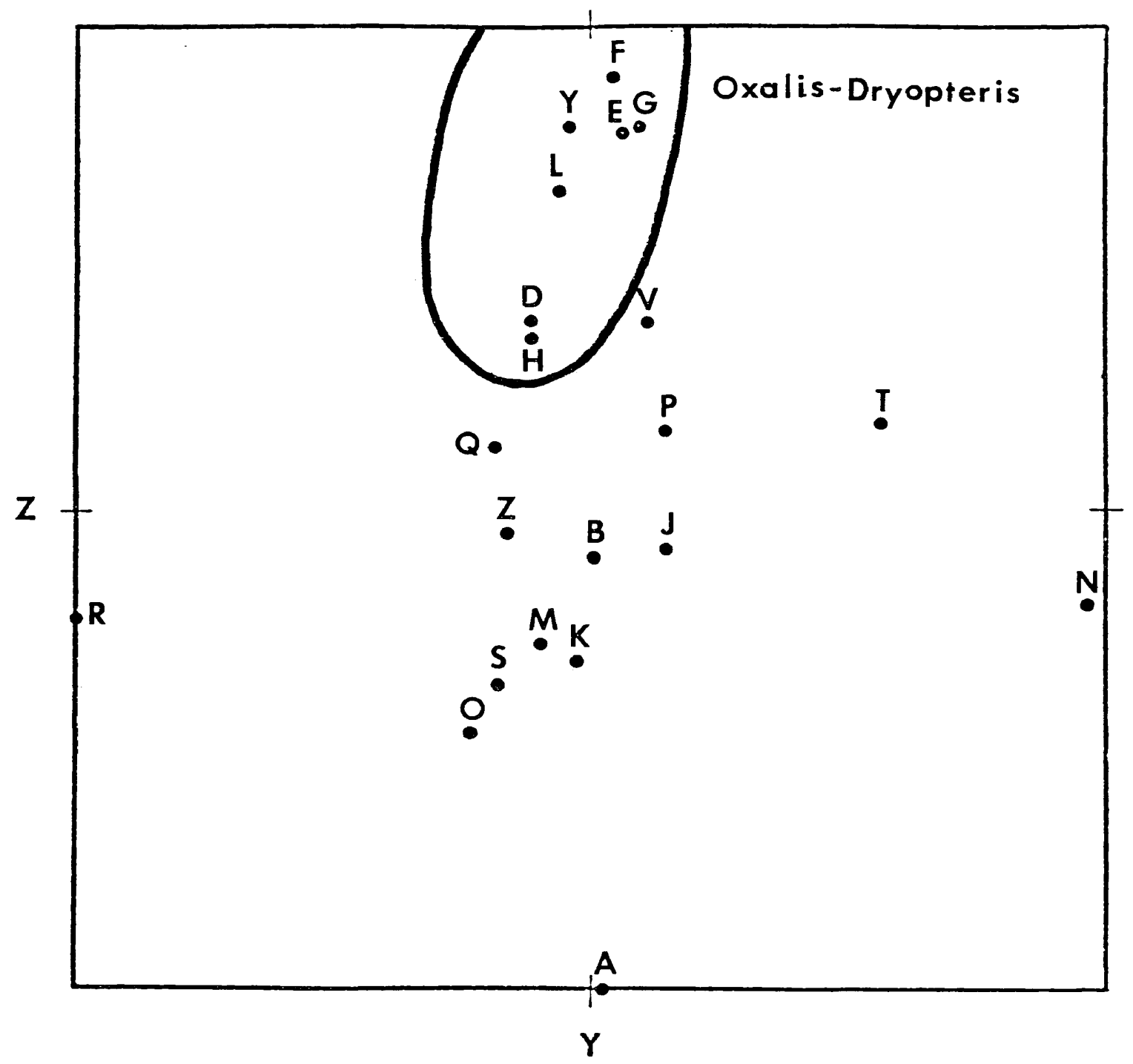

Figure 25. A polar ordination of sampled stands, $Y$ and $Z$ axes only, derived from herbaceous species importance values. The origin of the axes is in the lower left hand corner (compare with Fig. 24). 
A, Table 22).

Moisture does, however, correlate with the $\mathrm{X}$ axis, as does $\mathrm{pH}$ and elevation, both of which also correlate with moisture (Table 4). Stand $Z$, the only xeric ridge stand sampled in this study, is positioned at the opposite end of the $X$ axis (Fig. 24) from the much more moist, high elevation Oxalis-Dryopteris dominated stands, and is also far removed from the middle of the $X$ axis. If available soil moisture does indeed represent a gradient along this axis, then the overwhelming majority of stands are located at the high end of the moisture gradient.

The $Y$ axis of the herbaceous species ordination shows a positive correlation with the amount of organic matter in the soil, and perhaps consequently, a negative correlation with $\mathrm{pH}$ levels (at the .05 and the .01 levels, respectively). The two end stands of this axis have the highest and lowest concentrations of organic matter (stand N: 15\% and stand R: 6.3\%; Tables 13 and 15$)$. However, since not much separation occurs among the stands of intermediate composition (those near the middle of the axis), this parameter may not be extemely important in influencing the distribution of herbaceous vegetation in the Balsams.

One environmental parameter, calcium, deserves particular attention. It is generally recognized by plant ecologists that soils with higher calcium levels generally harbor more luxuriant vegetation, presumably because calcium levels correspond to calcium carbonate concentrations, which tend to neutralize acidic soils. Correlation analyses (Table 4) show that soils in the Balsam Mountains with higher calcium levels are less acidic (at the .01 level). Stands in mixed mesophytic, mesophytic-oak, and lower elevation communities tend to have higher calcium levels (and higher pH values) and more luxuriant 
vegetation. These communities also have the highest average diversity indices (Appendix A, Table 23): 2.81 for mixed mesophytic communities, 2.71 for lower elevation communities (based on stand R only), and 2.32 for mesophytic-oak communities. In addition, higher importance values of these 13 mesophytic species showed positive correlations with higher calcium levels: Asarum canadense, Botrychium virginianum, Caulophyllum thalictroides, Disporum lanuginosum, Dryopteris goldiana, Hydrophyllum canadense, Hydrophyllum virginianum, Polygonatum biflorum, Polystichum acrostichoides, Prenanthes altissima, Viola canadensis (a11 at the .01 1eve1), and Laportea canadensis and Trillium erectum (both at the .05 1eve1).

In 111,107 different herbaceous species were identified in this study (Appendix A, Table 17). However, onty the correlation results for the most important or widespread species (Maianthemum canadense, Dryopteris campyloptera, Eupatorium rugosum, Rubus canadensis, and Oxal is acetosella) will be verbally summarized below. The results of the correlations for these five species, along with those of 20 other common species are located in Appendix B, Tables 26 and 27.

The importance values of the fairly widespread and often important species, Majanthemum canadense, are recorded in Fig. 26 on the polar ordination. Although Maianthemum did not significantly correlate with any of the measured environmental parameters, the stands in which this species is more important are located at the high end of the $Y$ axis of the ordination. Hence, Maianthemum may be important in soils with more organic matter (or lower pH). High Maianthemum importance also correlates with the high importance of several other herbaceous species (a11 at the .01 leve1); Clintonia borealis, Convallaria majalis, Dennstaedtia 


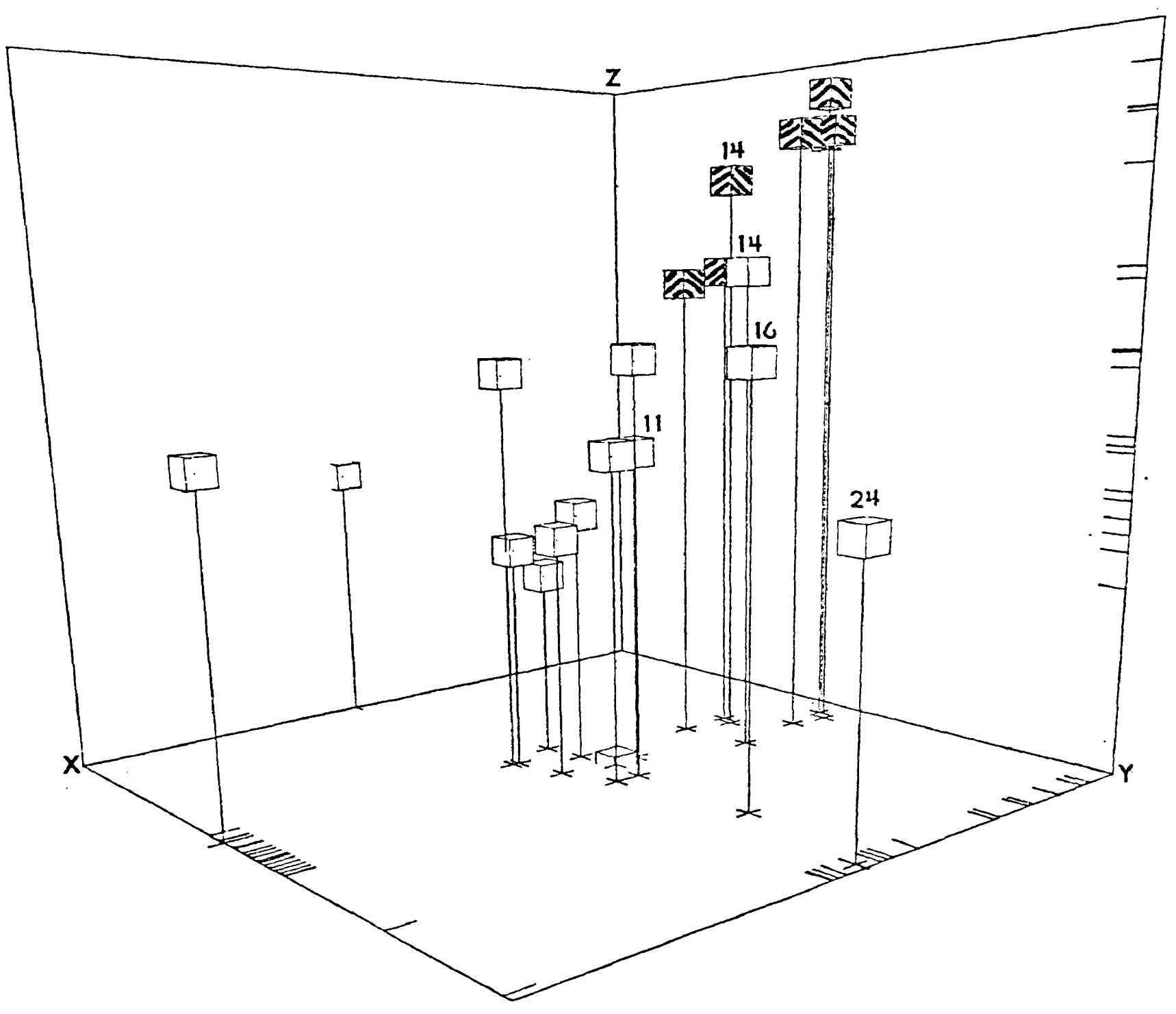

Figure 26. Importance values of Maianthemum canadense with respect to stand positions on the polar ordination. All importance values greater than 10 are recorded. Refer to legend in Fig. 24. 
punctilobula, Lycopodium lucidulum, Medeola virginiana, and Trillium undulatum (Table 16).

The widespread species, Dryopteris campyloptera (see Fig. 27), positively correlates with increased elevation and negatively with the the abundance of pebbles. (both at the .01 level). The negative relationship with the abundance of pebbles may be due to the higher organic content of the soils in the higher elevations. Dryopteris' importance also shows a negative correlation with high levels of magnesium (.05 level) in the soil, but this may be due to magnesium's negative correlation with elevation (Table 4). In addition, Dryopteris' importance shows positive correlations with the high importance of Lysimachia quadrifolia and Oxalis acetosel1a (both at the .05 leve1). Eupatorium rugosum (see Fig. 28), a common species in submesic and mesic stands, seems to be more important in areas with relatively high phosphorus concentrations (positive correlation at the .01 leve1). This is particularly interesting since phosphorus does not correlate with any of the other environmental parameters (Table 4). The importance of the grasses Brachyelytrum erectum and Festuca obtusa, as we11 as the herb Aster divaricatus, also correlate positively with the importance of Eupatorium.

Rubus canadensis (see Fig. 29) is probably the most widespread species occurring in the Balsams. Its average cover is usually not very high (maximum 35\% in stand Q, Fig. 6 and Table 11), but it is present in 13 of the 21 sampled stands. However, its importance did not correlate with any of the measured environmental variables. The importance of the grass Brachyelytrum erectum and the herb Mitche11a repens correlate positively (at the .05 and .01 levels, respectively) 
Table 16. Significant correlations between major herbaceous species and environmental variables, and among herbaceous species. A11 correlations are positive unless denoted by a "-" and were derived from importance values.

\begin{tabular}{|c|c|c|}
\hline & .05 Leve? & .01 Level \\
\hline Dryopteris campyloptera & $\begin{array}{l}\text { Lysimachia quadrifolia } \\
\text { Oxal is acetosella } \\
\text { (-) magnesium }\end{array}$ & $\begin{array}{l}(-) \text { abundance of pebbles } \\
\text { elevation }\end{array}$ \\
\hline Eupatorium rugosum & $\begin{array}{l}\text { Brachyelytrum erectum } \\
\mathrm{pH}\end{array}$ & $\begin{array}{l}\text { Aster divaricatus } \\
\text { phosphorus }\end{array}$ \\
\hline Maianthemum canadense & & $\begin{array}{l}\text { Clintonia umbellulata } \\
\text { Convallaria majalis } \\
\text { Dennstaedtia punctilobula } \\
\text { Lycopodium lucidulum } \\
\text { Medeola virginiana } \\
\text { Trillium undulatum }\end{array}$ \\
\hline Oxal is acetosella & $\begin{array}{l}\text { (-) Disporum lanuginosum } \\
\text { Dryopteris campyloptera } \\
\% \text { organic matter } \\
\text { soluble salts } \\
\text { zinc } \\
\text { (-) abundance of pebbles }\end{array}$ & $\begin{array}{l}(-) \text { Zizia aurea } \\
\text { elevation } \\
(-) \text { pH } \\
(-) \text { species diversity }\end{array}$ \\
\hline Rubus canadensis & Brachyelytrum erectum & Mitchella repens \\
\hline
\end{tabular}




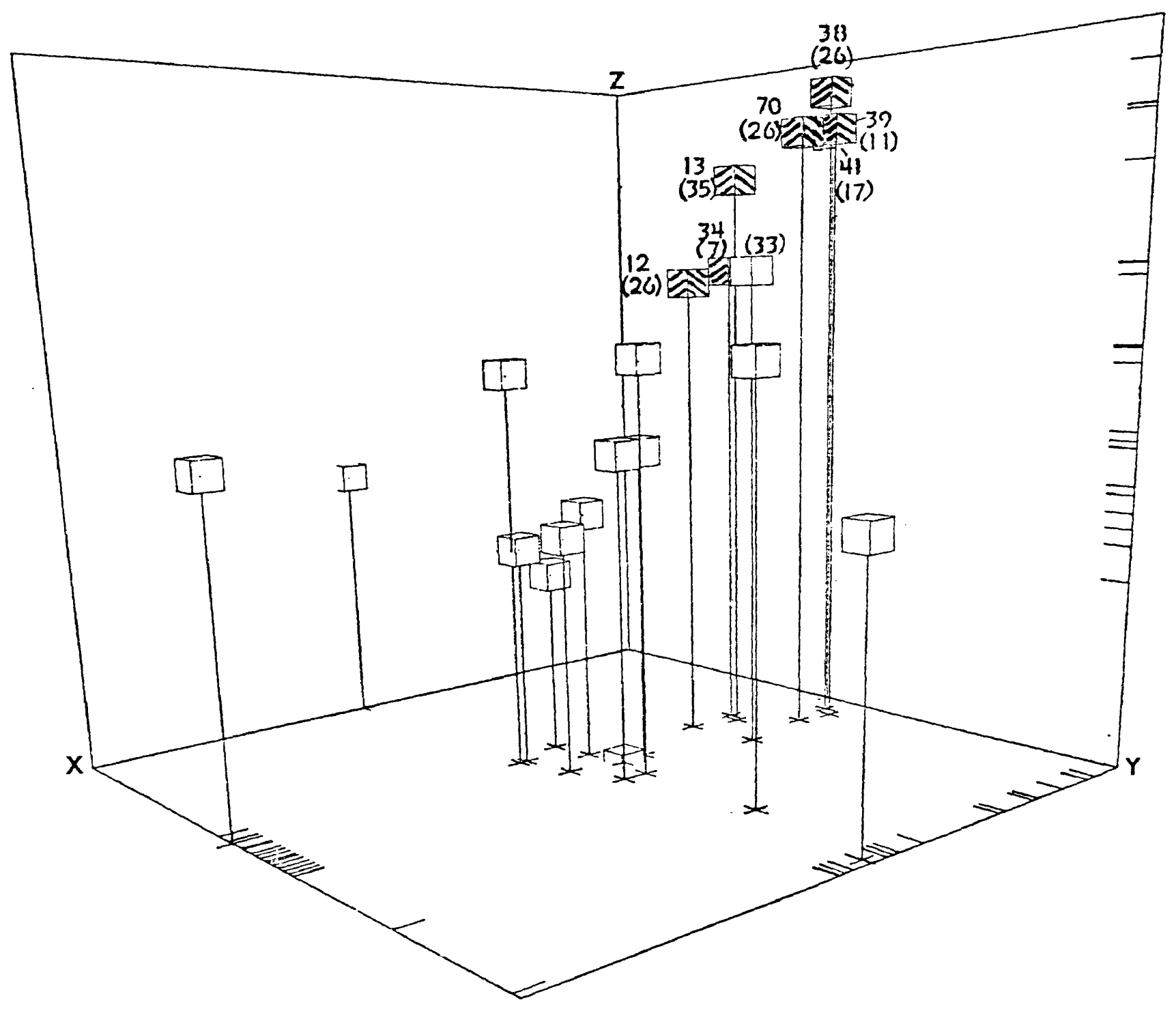

Figure 27. Importance values of 0 xal is acetosella and Dryopteris campyloptera (in parentheses) with restion. Al importance positions on the 10 are recorded for 0xalis and values greater than 10 are recorded for than 6 for Dryopteris. Refer to legend in Fig. 24. 


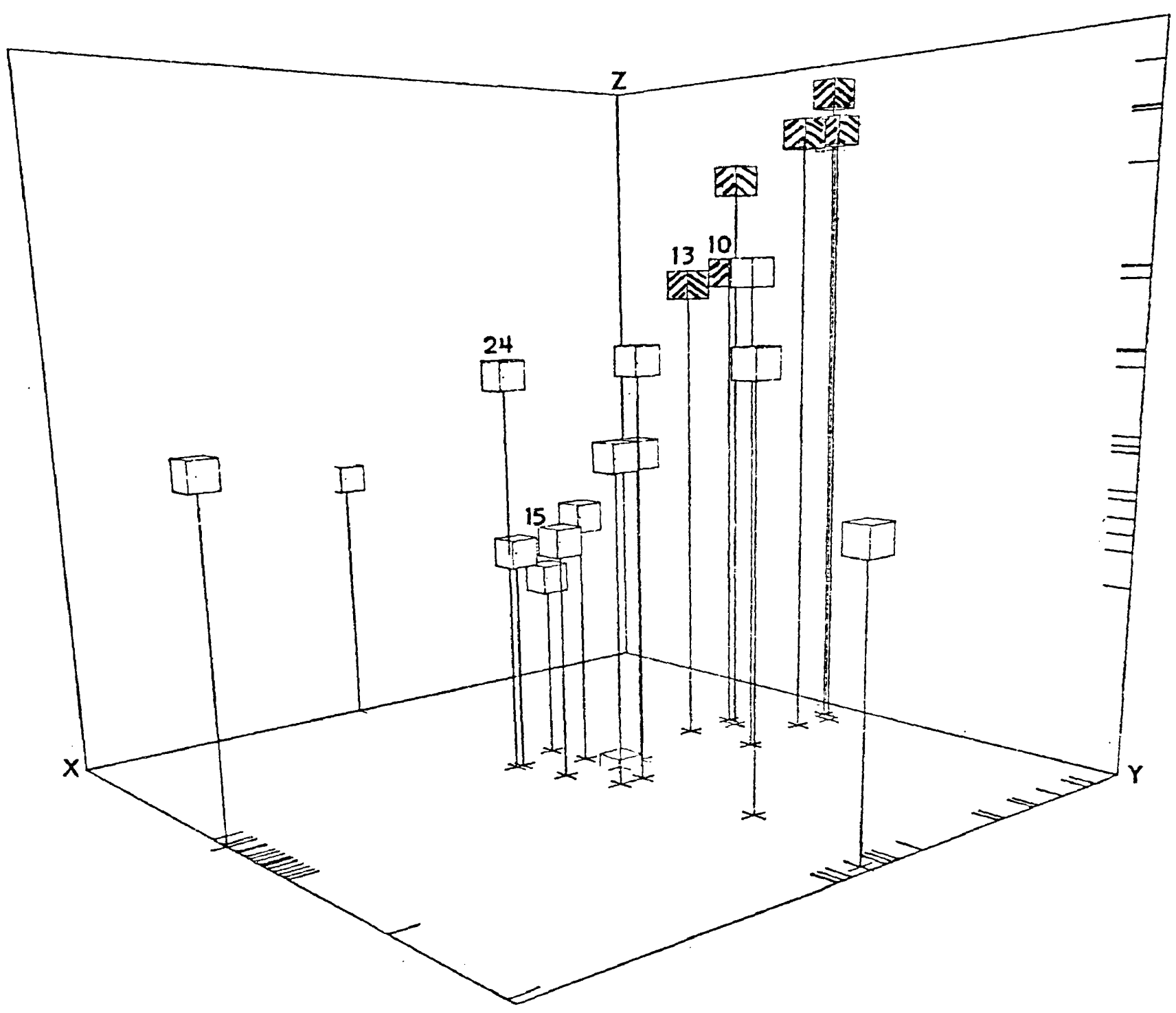

Figure 28. Importance values of Eupatorium rugosum with respect to stand positions on the polar ordination. All importance values greater than 10 are recorded. Refer to legend in Fig. 24. 


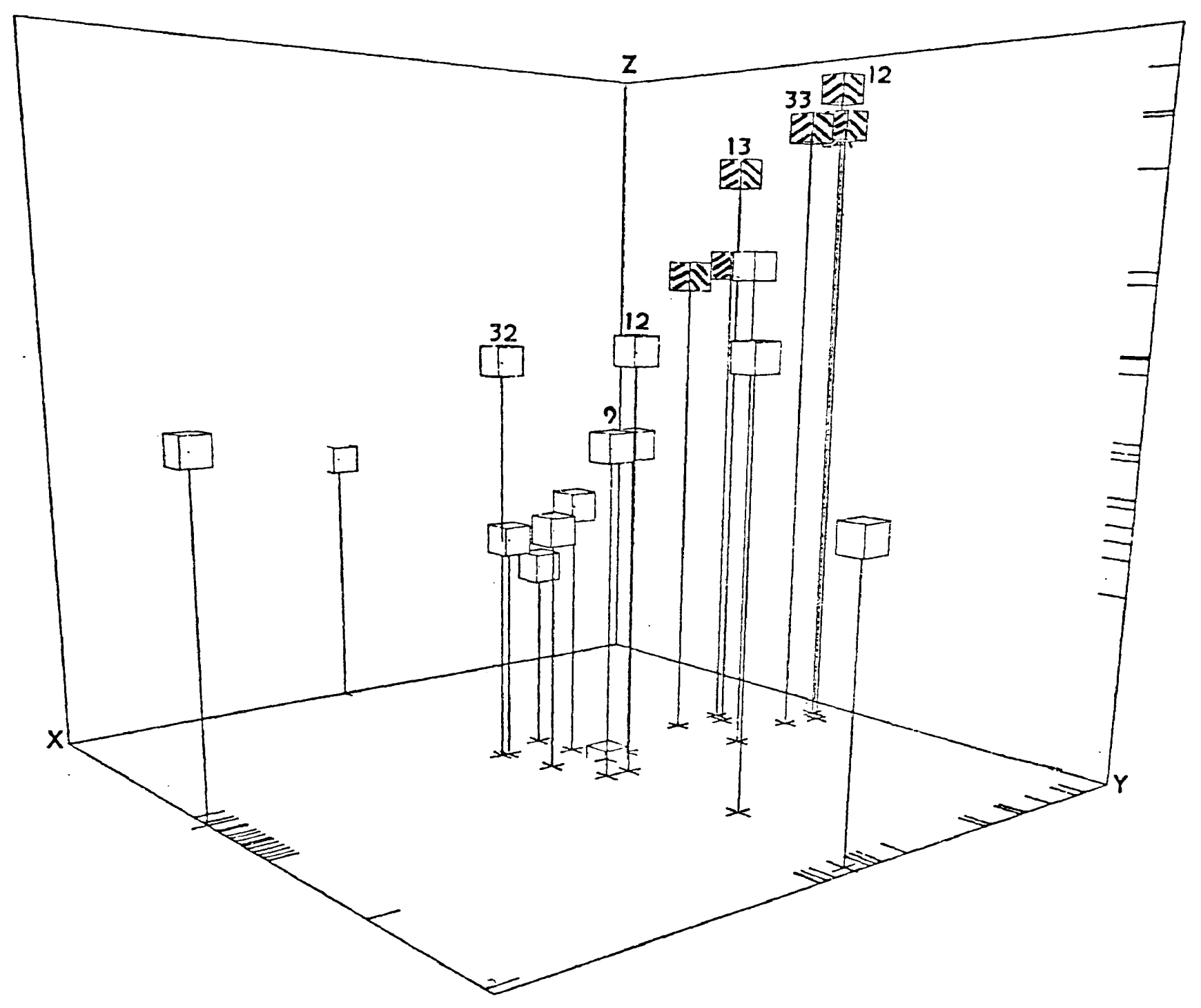

Figure 29. Importance values of Rubus canadensis with respect to stand positions on the polar ordination. A11 importance values of greater than 9 are recorded. Refer to legend in Fig. 24. 
with the importance of Rubus. This relationship may not be significant since Brachyelytrum occurs in only four stands and Mitchel1a in two.

Finally, 0xalis acetosella (note Fig. 27), a major herb constituent of higher elevation forests, was, as expected, correlated with elevation (at the .01 leve1). Its importance is also higher in soils with more organic matter (correlated at the .05 level), with higher soluble salt and zinc concentrations (.01 level), and is negatively correlated with species diversity (at the .01 level). High 0xalis dominance also correlates positively with high Dryopteris campyloptera dominance and low Disporum lanuginosum dominance (both at the .05 level). 


\section{DISCUSSION}

Herbaceous vegetation

The distribution of herbaceous vegetation in the Balsam Mountains appears to show little relation to that of the woody vegetation. From the analysis of the herbaceous polar ordination, it seems that elevation is probably the major environmental parameter influencing herbaceous community structure. In fact, eievation may entirely supercede any influence exhibited by or controlling the composition of the canopy.

Other, presumably less influential factors, may include moisture and the amount of organic matter in the soil. Although moisture is traditionally considered to be an important limiting parameter affecting the distribution of vegetation, slight differences in moisture may be less important to the herbaceous vegetation in the Balsam Mountains because of the very high moisture content of almost all the soils there. During most of this study, which was conducted during one of the driest summers ever recorded in Virginia, available moisture in most stands rarely fell below $85 \%$. Few species, and none of the five most important species discussed, showed a consistently significant correlation with available moisture.

The herbaceous vegetation of the open slopes in the Balsams seems to be uncharacteristically luxuriant based on the descriptions of Braun (1950), Whittaker (1956), and others on the forests of the southern Blue Ridge. Average herbaceous species diversity indices (Appendix A, Table 23) are highest in the three most mesophytic communities: 
mixed mesophytic (2.81), lower elevation (2.71), and mesophytic-oak (2.32), which also tend to have higher calcium levels (and consequently higher $\mathrm{pH}$ ) than the other community-types in the study. The luxuriance of these stands is probably influenced by the presence of calcium, particularly since 13 mesophytic herbaceous species show an exceptionally strong correlation with calcium levels, although the soils of these communities are definately not derived from calcareous substrates. It may be the combination of relatively high calcium and available moisture levels which enables open slopes to harbor such luxuriant vegetation, thus providing an environment normally restricted to cove forests in the remainder of the southern Blue Ridge Province.

Woody vegetation

Two different boreal coniferous forest communities exist under seemingly similar topographic-climatic conditions in the Balsams. A spruce-fir forest occupies the highest elevations on Mount Rogers while Whitetop's summit harbors a spruce forest, fir being entirely absent there. The spruce-fir forest on Mount Rogers extends downslope to $1500 \mathrm{~m}$ in elevation. Since Whitetop peaks at $1682 \mathrm{~m}$, the upper $182 \mathrm{~m}$ of Whitetop should be environmentally suitable for the development of a spruce-fir forest.

A shifting in ecotonal boundaries to higher elevations mav have occurred in the Balsams during the last post-glacial xerothermic period, resulting in the elimination of the higher elevation fir (but not the lower elevation spruce) from Whitetop Mountain. If so, then fir must have been able to find refuge at the higher elevations of Mount Rogers, since it exists there today. As global temperatures again began to cool, 
fir must have migrated down the slopes of Mount Rogers to its present distributional limit - $182 \mathrm{~m}$ lower than the height of Whitetop's summit. Since Whitetop and Mount Rogers are separated by a relatively low elevation gap at Elk Garden (Fig. 4), fir has been prevented from reoccupying the higher elevations of Whitetop Mountain, where climatic conditions seem suitable for its establishment. A similar scenario was hypothesized by Whittaker (1956) as having possibly occurred in the Great Smoky Mountains, with respect to spruce and fir verses hardwoods on peaks, but not for the separation of spruce and fir.

Another interesting finding concerning the distribution of sprucefir forests in the Balsams is that they do not extend to as low an elevation as might be expected based on their distribution in the Great Smokies. Spruce-fir forests extend downward to about $1370 \mathrm{~m}$ in elevation in the Great Smokies (Whittaker, 1956), but to only $1500 \mathrm{~m}$ in the Balsams. However, since Mount Rogers is $117 \mathrm{~km}$ north in latitude from the Great Smokies, elevational ranges should be 1 owered by about $290 \mathrm{~m}^{3}$; instead spruce-fir ecotonal boundaries occur $130 \mathrm{~m}$ higher in elevation than they do in the Smokies. According to Shields (1962), most of the logging of spruce and spruce-fir forests in the Balsams occurred between 1905 and 1920. He suggests, based on his research of timber extraction records that coniferous forests (spruce, fir, and hemlock) were once much more extensively distributed than when he was doing his study (1ate 1950's). Perhaps fir seeds are unable to disperse very great distances, resulting in a slow recovery of spruce-fir forests on the lower slopes. Shields

3 This assumes a $1.01^{\circ} \mathrm{C}$ drop in mean annual temperatures for every $100 \mathrm{~km}$ north in latitude and a $.406^{\circ} \mathrm{C}$ decrease in temperature for every $100 \mathrm{~m}$ increase in elevation. 
noted, for instance, that on nearby Beartown Mountain in the Ridge and Valley Province, mixed hardwoods (Fagus, Tilia, Acer saccharum, Aesculus, and Amelanchier) had replaced spruce on the heavily logged south slopes. However, on Beartown Mountain, spruce was replacing Tilia in the smaller size classes, thus suggesting that spruce might again establish dominance.

Perhaps, then, spruce and spruce-fir forests once extended much further down the slopes of the Balsams and were replaced by mesic hardwoods after logging. This is strictly conjecture, however, since there are no records pertaining to the extent of subalpine forests prior to logging, and unlike on Beartown Mountain, there is little evidence that spruce is increasing under the higher elevation hardwoods in the Balsams.

Whittaker (1956: 46) regarded deciduous forests in the upper reaches of coves in the Great Smokies as a subtype of the cove (mixed mesophytic) forest, since there was increased coverage of Aesculus, Tilia, and Betula, with a concomitant absence of Liriodendron and Isuga. The high elevation mixed mesophytic forest-type of the Balsams is similar in composition to these upper cove forests of the Smokies, but untike the Smokies, the Balsam's mesophytic forests occur on open slopes, rather than being restricted to coves. While the vegetational composition of open slopes of primarily north and east aspects resembles the mixed mesophytic forests of high elevation coves in the Great Smokies, the forests of drier south and west exposures (mesophytic-oak communities) resemble the "cove forest transition" communities (transitional between the cove forests and the northern red oak forests of open slopes) described by Whittaker (1956). Elsewhere in the southern Blue Ridge Province, northern red oak forests are dominant on open slopes at these elevations (Braun, 1950; Whittaker, 1956). 
Like the cove forests, mixed mesophytic forests of open slopes in the Balsams are rich in both woody and herbaceous species. The mixed mesophytic stands show the highest average diversity indices $\left(H^{\prime}\right)$ for woody species (1.76) and for herbs (2.81) of any of the seven communitytypes occurring above $1150 \mathrm{~m}$ in elevation, while the mesophytic-oak communities show the second highest ( 1.73 for woody species and 2.33 for herbaceous species). However, the mesophytic-oak stands contain a much higher number of understory species (14 species) than either the mixed mesophytic ( 6 species) or northern red oak ( 9 species) communities. Whittaker did not mention whether or not he found this to be true for cove transition communities in the Great Smokies.

Both the Balsams and the Great Smokies receive large amounts of precipitation [approximately $170 \mathrm{~cm}$ annually in the Balsams (Shelton, personal communication), and greater than $200 \mathrm{~cm}$ annually in the higher elevations of the Great Smokies (Whittaker, 1956)]. It is surprising then that the two areas differ so remarkably in the mesicness of their open slope vegetation. Soil moisture measurements have apparentiy never been published for the Great Smokies, but in the Balsams, even during one of the driest summers on record, the available soil moisture in most stands exceeded $85 \%$ (Appendix A, Table 22).

In only one other area in the southern Blue Ridge Province have forests resembling mixed mesophytic communities been described as occurring on open slopes. Braun (1950:218, 219) and 0osting (1941) mention that unusualiy mesic vegetation occurs on the extemely steep, northfacing slopes of the Nantahala River gorge near Joyce Kilmer Memorial Forest in North Carolina. It was their belief that the rich, calcareous soil of those slopes is responsible for their unusually mesic nature. 
However, the slopes of the Nantahala gorge are almost vertical and so are not physiographically analogous to those of the Balsams, and although the soils of the mixed mesophytic and mesophytic-oak communities in the Balsams also contain relatively higher calcium concentrations (Appendix A, Table 22) than other stands, the soils are definitely not derived from a calcareous substrate.

Elsewhere in the Oak-Chestnut forest region, mixed mesophytic communities seem to be restricted to protected coves where they form the cove hardwoods complex often described by Whittaker (1956), Braun (1950), and others for the Great Smokies. Only in the Cumberland Mountains and in the southern Alleghenies, which together comprise the Mixed Mesophytic Forest Region, do mixed mesophytic forests commonty cover open slopes. The vegetation of the Balsams differs somewhat in composition from that of the Mixed Mesophytic Forest Region due to the much higher elevations of the Balsams. Yet, the mesic and mixed nature of the woody vegetation, and the luxuriance of the herbaceous stratum indicates close relationship with the Mixed Mesophytic association.

The most xerophytic communities in the southern Blue Ridge Province are those of sharp, southwest-facing ridges. One such stand was studied in the Balsams (stand Z, Fig. 8 and Table 13) and proved to be in fact, the most xerophytic of all the stands sampled. However, its composition is not nearly as xerophytic as is usual for such ridge stands elsewhere in the southern Blue Ridge, where Pinus pungens dominates comparable elevations (Whittaker, 1956). In the Balsams, ridges support species such as Quercus rubra, Quercus prinus, and in the past, Castanea dentata, species more characteristic of open slopes in the Great Smokies.

Thus, even ridges in the Balsams are more mesophytic than most of their conterparts in the rest of the southern Blue Ridge Province. 
However, Braun (1950:81) described ridge stands in the Allegheny Mountains (in the Mixed Mesophytic Forest Region) which were very similar in composition to those of the Balsams. These "ridge timber" communities, as Shreve (1910) called them, were dominated by Castanea, Quercus prinus, and Quercus rubra.

Ravine communities in the Balsams (see stands $E$ and $51, F i g .7$ and Table 9) are dominated primarily by Betula lutea (yellow birch), although significant amounts of Magnolia fraseri and Isuga canadensis (hemlock) are present as wel1. Since yellow birch is usually considered to be a seral tree in the southern Appalachians, this suggets that Lewis Fork ravine may still be undergoing succession. Succession is also indicated by the fact that Lewis Fork was logged around 1920 (Shields, 1962). Further, a massive flood in 1968 may explain why. few stems, with the exception of those of Rhododendron maximum, appear in the sapling and Targer seedling categories.

Reed (1905) called similar high elevation valley communities in the Grandfather Mountain area of North Carolina "hemlock bottoms", since hemlock is the dominant species. However, he lists yellow birch as the second most important tree (in fact nearly as important as hemlock) in this community. The flat bottoms of Lewis Fork are not as broad as those described by Reed, but perhaps the potential climax will be similar. At present, however, it is difficult to determine what the future composition will be, since one would have to rely on the composition of the small seedling category, a category of dubious predictive value, as a basis of extrapolation.

It is surprising that the mesophytic, mixed nature of the open slope forests of the Balsams had not been previously recognized. Perhaps it is because only the boreal forests on these mountains had been 
carefully studied.

Mount Rogers may not be nearly unique in the southern Blue Ridge in its mesicness. There is a distinct possibility that Roan Mountain (approximately $75 \mathrm{~km}$ to the south-southwest) also harbors mixed mesophytic communities on its lower slopes. Harshberger (1910) listed lower elevational mesic species such as Liriodendron, Tilia, Aesculus, and Eagus as occurring on Roan Mountain. However, it is not clear whether the list was derived from coves or from open slopes.

The vegetation of Roan Mountain was quantitatively studied by Brown (1941), but only northern hardwoods between 1400 and $1463 \mathrm{~m}$ in elevation and spruce-fir forests were sampled. He indicated that the forests of the lower elevations were mostly disturbed, but that beechmaple forest extend from $1500 \mathrm{~m}$ down to $1000 \mathrm{~m}$ in elevation. Shie]ds (1962) erroneously noted that beech-maple forests on Mount Rogers extend down the slopes to approximately $1200 \mathrm{~m}$ where they supposed7y change to "a mixed hardwood-hemlock" association". Brown may have similarly been in error with respect to Roan Mountain.

Barring a recent disturbances, the low elevation forests of Roan Mountain may now be suitable for sampling. While Roan Mountain is a bit farther removed from the Mixed Mesophytic Forest Region than is Mount Rogers and thus may not have developed extensive open slope mesophytic communities, a phytosociological study conducted on its lower elevations could be a very interesting comparison with the Balsam Mountain area. 


\section{APPENDIX A}

Fifty-six woody species (including 32 canopy species) and 105 herbaceous species were identified in the study area. Table 17 separates a 11 161 species according to stratum and lists them in alphabetial order. Nomenclature follows Radford, Ahles, and Bell (1974), except that the taxon treated as Amelanchier arborea var. laevis is here reported as Amelanchier laevis Wiegand. Some "shrub" species occasionally become canopy-sized, but they have been placed in the shrub category because the species exert their influence primarily in the understory. Two herbaceous species could not be identified in one or two stands and so are not included in this list.

Table 18 summarizes the importance, relative dominance, and relative density values of each canopy species occurring in the 21 sampled stands. Canopy values 1 isted in Tables 7-12 are relative dominance values. Absolute dominance values and density values of saplings (all stems less than $10 \mathrm{~cm} \mathrm{dbh}$, but greater than $1.5 \mathrm{~m}$ high), larger seedlings (all stems less than $10 \mathrm{~cm}$ dbh and .5 to $1.5 \mathrm{~m}$ high), and small seedlings (all stems Tess than $.5 \mathrm{~m}$ high). Again, absolute values for each species may be determined by multiplying the total density by the appropriate relative density values and then dividing by 100. A "-" means that the species was observed in the stand, but was not encountered in a sample plot.

Table 20 summarizes the herbaceous data from the 21 sampled stands in order of decreasing importance values. The importance values, however, are located in Tables 7-15 and were derived by averaging each species' 
relative coverage and relative frequency values. An " $X$ " means that the species was present in a sample plot, but had less than $1 \%$ coverage. A "-" means that the species was encountered in the stand, but not in a sample plot.

Table 21 lists the ordination positions of each stand with respect to the three separate ordinations, based on relative dominance values and importance values of woody species, and the importance values of herbaceous species.

Table 22 lists the environmental measurements determined for each of the 21 sampled stands and four of the listed stands. Minerals are measured in parts per milition (ppm), pebble abundance measurements correspond to the classifications defined in Table 2, and the three moisture measurements (in \% available soil moisture) correspond to three separate readings. A "-" means that the measurement was not made.

Table 23 summarizes the diversity indices for each stand. Separate indices were calculated using relative dominance, relative density, and importance values for woody species and importance values for herbaceous species. 
Table 17. Vascular flora of the Balsam Mountains. Nomenclature follows that of Radford, Ahles, and Bell (1978), except where noted.

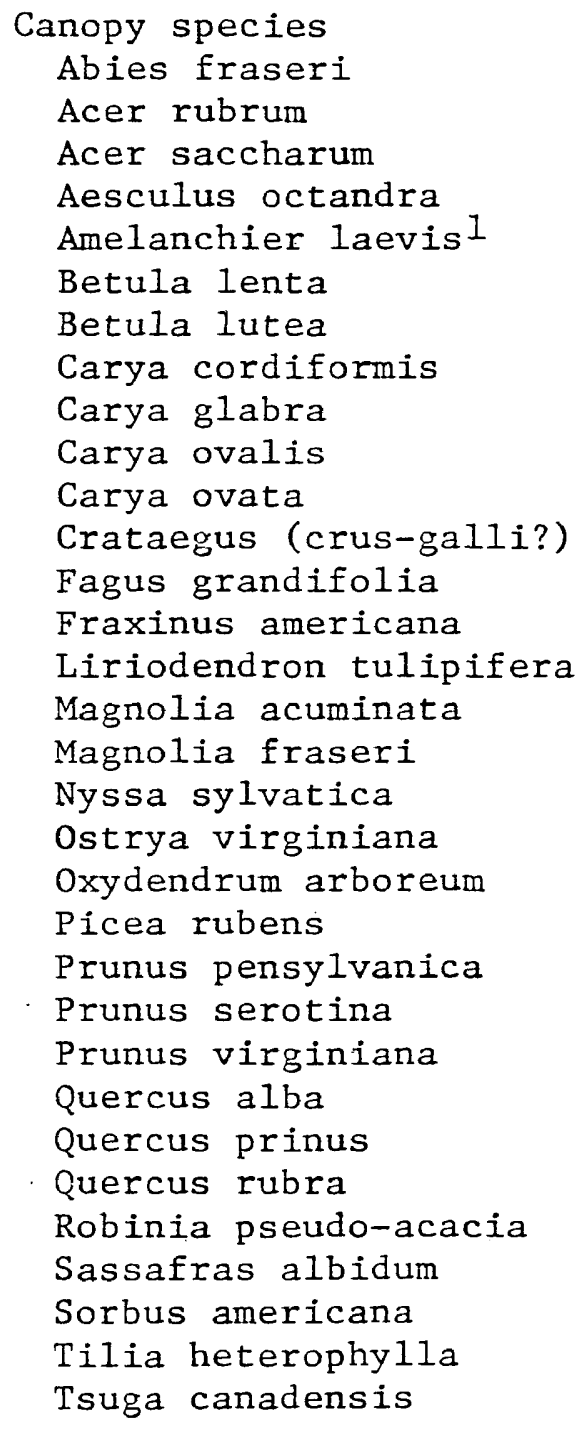

Continued

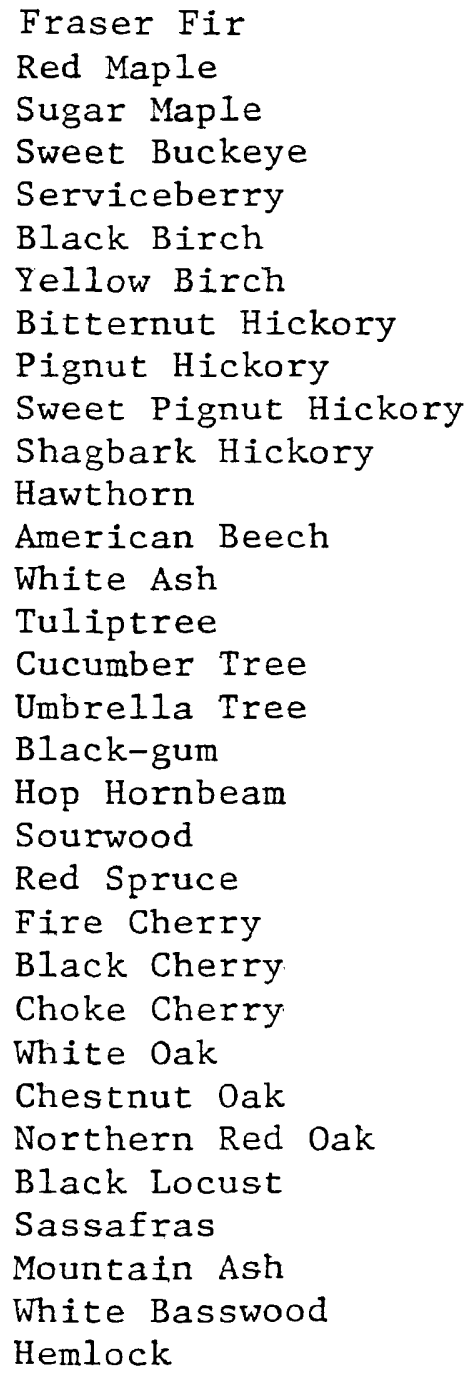

\footnotetext{
ITreated as A. aborea var. Iaevis (Wiegand) Ahles by Radford et al. (1978).
} 
Table 17 Continued

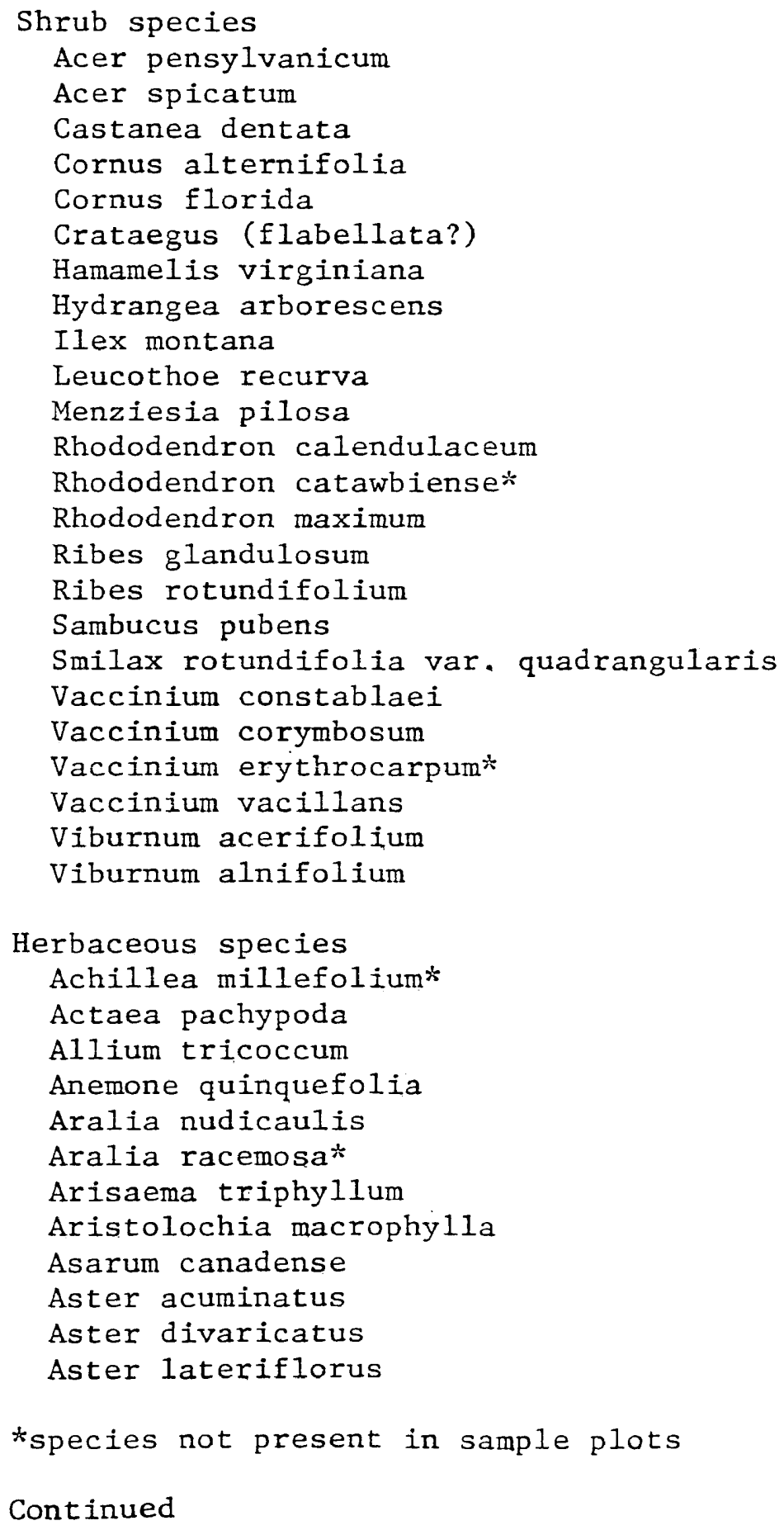


Table 17 Continued

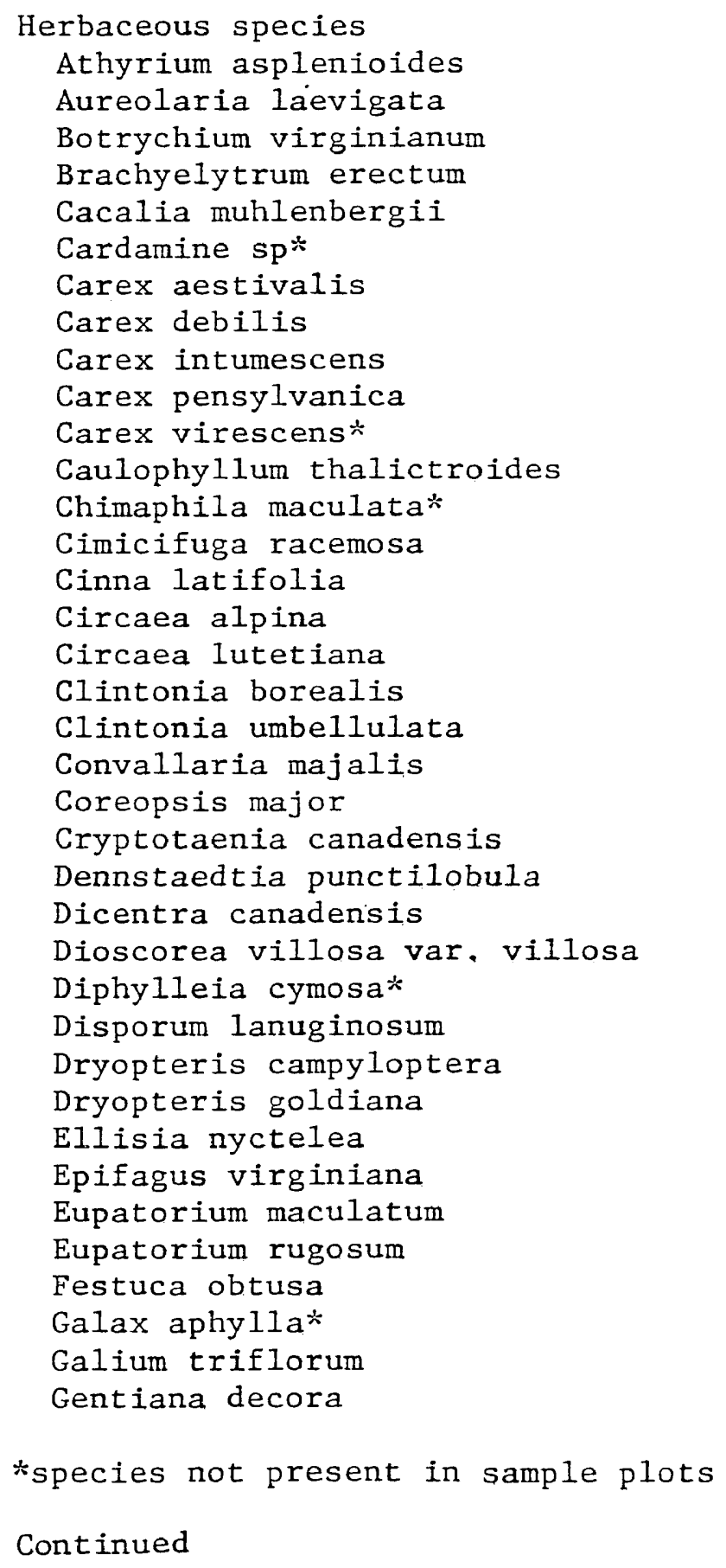




\section{Table 17 Continued}

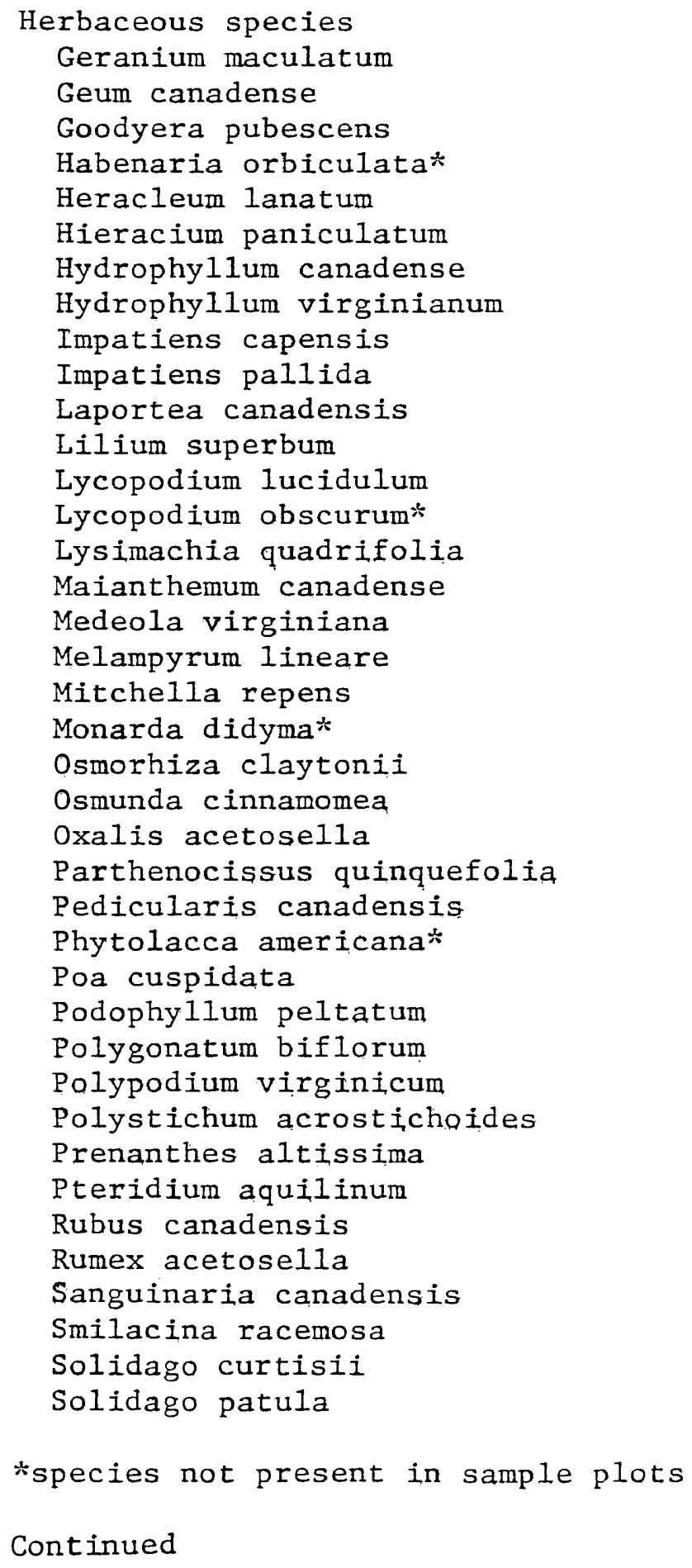


Table 17 Continued

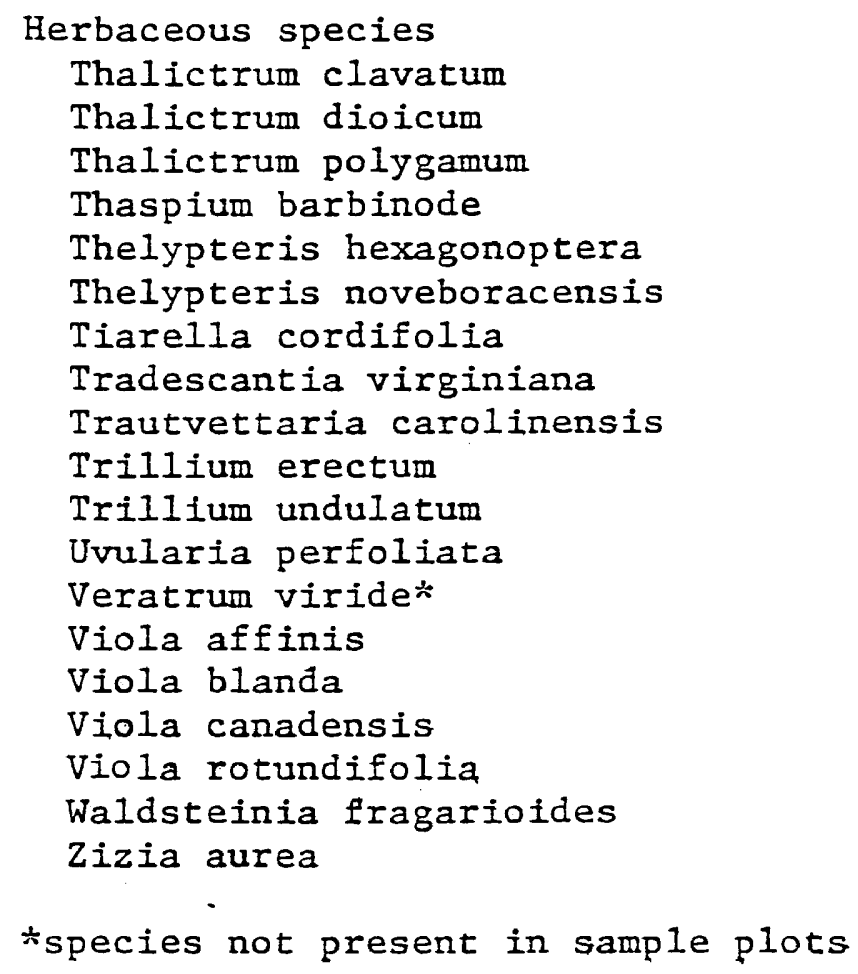


111.

Table 18. Importance, dominance, and density values for canopy species, by stand. There are no stands C, I, U, W, or $\mathrm{x}$.

Importance
value $\quad \begin{gathered}\text { Dominance } \\ \text { (\%basal area) }\end{gathered} \quad$ Density (\%)

\begin{tabular}{|c|c|c|c|}
\hline \multicolumn{4}{|l|}{$\begin{array}{l}\text { Stand } A \\
\text { Basal area: } 37.2 \mathrm{~m}^{2} / \text { ha } \\
\text { Density: } 435 \text { stems/ha }\end{array}$} \\
\hline $\begin{array}{l}\text { Tilia heterophylla } \\
\text { Acer saccharum } \\
\text { Fraxinus americana } \\
\text { Betula lutea } \\
\text { Fagus grandifolia } \\
\text { Quercus rubra } \\
\text { Acer pensylvanicum } \\
\text { Betula lenta } \\
\text { Ostrya virginiana } \\
\text { Prunus serotina }\end{array}$ & $\begin{array}{r}27.4 \\
22.9 \\
16.2 \\
13.5 \\
13.4 \\
4.7 \\
.6 \\
.4 \\
.4 \\
.4\end{array}$ & $\begin{array}{r}26.8 \\
25.0 \\
21.4 \\
6.2 \\
13.4 \\
4.5 \\
- \\
.9 \\
.9 \\
.9\end{array}$ & $\begin{array}{r}28.0 \\
20.7 \\
11.0 \\
20.7 \\
13.4 \\
4.9 \\
1.2 \\
- \\
= \\
-\end{array}$ \\
\hline \multicolumn{4}{|l|}{$\begin{array}{l}\text { Stand B } \\
\text { Basal area: } 34.8 \mathrm{~m}^{2} / \text { ha } \\
\text { Density: } 493 \text { stems/ha }\end{array}$} \\
\hline $\begin{array}{l}\text { Acer saccharum } \\
\text { Fagus grandifolia } \\
\text { Amelanchier laevis. } \\
\text { Betula lutea } \\
\text { Quercus rubra } \\
\text { Ostrya virginiana } \\
\text { Fraxinus americana } \\
\text { Acer pensyivanicum } \\
\text { Aesculus octandra } \\
\text { Betula lenta } \\
\text { Magnolia acuminata } \\
\text { Prunus serotina }\end{array}$ & $\begin{array}{r}30.8 \\
30.7 \\
8.6 \\
5.9 \\
5.5 \\
4.1 \\
3.4 \\
3.1 \\
3.0 \\
2.0 \\
1.5 \\
1.5\end{array}$ & $\begin{array}{l}29.2 \\
30.2 \\
7.6 \\
7.6 \\
6.6 \\
2.8 \\
4.7 \\
1.9 \\
2.8 \\
2.8 \\
1.9 \\
1.9\end{array}$ & $\begin{array}{r}32.3 \\
31.2 \\
9.7 \\
4.3 \\
4.3 \\
5.4 \\
2.2 \\
4.3 \\
3.2 \\
1.1 \\
1.1 \\
1.1\end{array}$ \\
\hline \multicolumn{4}{|l|}{$\begin{array}{l}\text { Stand } D \\
\text { Basal area: } 38.5 \mathrm{~m}^{2} / \text { ha } \\
\text { Density: } 637 \text { stems/ha }\end{array}$} \\
\hline $\begin{array}{l}\text { Fagus grandifolia } \\
\text { Acer saccharum } \\
\text { Betula lutea } \\
\text { Aesculus octandra } \\
\text { Fraxinus americana } \\
\text { Prunus serotina } \\
\text { Amelanchier laevis } \\
\text { Hamamelis virginiana }\end{array}$ & $\begin{array}{r}61.0 \\
26.9 \\
5.1 \\
3.2 \\
1.3 \\
1.3 \\
.6 \\
.6\end{array}$ & $\begin{array}{r}54.6 \\
35.1 \\
3.9 \\
2.6 \\
1.3 \\
1.3 \\
1.3 \\
-\end{array}$ & $\begin{array}{r}67.5 \\
18.7 \\
6.2 \\
3.7 \\
1.2 \\
1.2 \\
- \\
1.2\end{array}$ \\
\hline
\end{tabular}

Continued 
Table 18 Continued

\begin{tabular}{|c|c|c|c|}
\hline & $\begin{array}{l}\text { Importance } \\
\text { value }\end{array}$ & $\begin{array}{c}\text { Dominance } \\
\text { (\%basal area) }\end{array}$ & Density $(\%)$ \\
\hline \multicolumn{4}{|l|}{$\begin{array}{l}\text { Stand } E \\
\text { Basal area: } 36.5 \mathrm{~m}^{2} / \mathrm{ha} \\
\text { Density: } 526 \text { stems/ha }\end{array}$} \\
\hline \multicolumn{4}{|l|}{ species } \\
\hline $\begin{array}{l}\text { Betula lutea } \\
\text { Magnolia fraseri } \\
\text { Tsuga canadensis } \\
\text { Picea rubens } \\
\text { Prunus serotina } \\
\text { Acer pensylvanicum } \\
\text { Amelanchier Taevis } \\
\text { Fagus grandifolia } \\
\text { Acer rubrum }\end{array}$ & $\begin{array}{r}39.2 \\
19.4 \\
17.0 \\
9.3 \\
4.9 \\
3.6 \\
2.9 \\
2.1 \\
1.4\end{array}$ & $\begin{array}{r}31.5 \\
20.5 \\
21.9 \\
9.6 \\
6.8 \\
2.8 \\
2.8 \\
2.8 \\
1.4\end{array}$ & $\begin{array}{r}47.0 \\
18.2 \\
12.1 \\
9.1 \\
3.0 \\
4.5 \\
3.0 \\
1.5 \\
1.5\end{array}$ \\
\hline \multicolumn{4}{|l|}{$\begin{array}{l}\text { Stand } F \\
\text { Basal area: } 21 \mathrm{~m}^{2} / \mathrm{ha} \\
\text { Density: } 461 \text { stems } / \text { ha }\end{array}$} \\
\hline \multicolumn{4}{|l|}{ species } \\
\hline $\begin{array}{l}\text { Betula lutea } \\
\text { Picea rubens } \\
\text { Amelanchier laevis } \\
\text { Acer pensylvanicum } \\
\text { Acer spicatum } \\
\text { Fagus grandifolia } \\
\text { Sorbus americana }\end{array}$ & $\begin{array}{r}61.3 \\
28.4 \\
2.9 \\
2.1 \\
2.1 \\
2.1 \\
1.2\end{array}$ & $\begin{array}{r}57.1 \\
31.0 \\
2.4 \\
2.4 \\
2.4 \\
2.4 \\
2.4\end{array}$ & $\begin{array}{r}65.5 \\
25.9 \\
3.5 \\
1.7 \\
1.7 \\
1.7 \\
-\end{array}$ \\
\hline \multicolumn{4}{|l|}{$\begin{array}{l}\text { Stand } \mathrm{G} \\
\text { Basal area: } 42 \mathrm{~m}^{2} / \mathrm{ha} \\
\text { Density: } 621 \text { stems/ha }\end{array}$} \\
\hline \multicolumn{4}{|l|}{ species } \\
\hline $\begin{array}{l}\text { Abies fraseri } \\
\text { Betula lutea } \\
\text { Picea rubens } \\
\text { Acer pensylvanicum } \\
\text { Sorbus americana } \\
\text { Aesculus octandra }\end{array}$ & $\begin{array}{r}38.8 \\
34.0 \\
24.7 \\
1.2 \\
.6 \\
.6\end{array}$ & $\begin{array}{r}41.7 \\
31.0 \\
25.0 \\
1.2 \\
-. \\
1.2\end{array}$ & $\begin{array}{l}35.9 \\
37.2 \\
24.4 \\
1.3 \\
1.3 \\
-\end{array}$ \\
\hline
\end{tabular}

Stand $H$

Basal area: $39.3 \mathrm{~m}^{2} / \mathrm{ha}$

Density: 509 stems/ha

species

Acer sacchiarum

Picea rubens

Aesculus octandra

Betula lutea

Abies fraseri

Fagus grandifolia

Crataegus (crus-galli?)

33.2
24.8
18.9
10.8
5.7
3.8
2.9

$\begin{array}{rr}28.8 & 37.5 \\ 28.8 & 20.8 \\ 16.9 & 20.8 \\ 15.3 & 6.2 \\ 5.1 & 6.2 \\ 3.4 & 4.2 \\ 1.7 & 4.2\end{array}$

Continued 
113.

Table 18 Continued

\begin{tabular}{|c|c|c|c|}
\hline & $\begin{array}{c}\text { Importance } \\
\text { value }\end{array}$ & $\begin{array}{c}\text { Dominance } \\
\text { (\%basal area) }\end{array}$ & Density (\%) \\
\hline \multicolumn{4}{|l|}{$\begin{array}{l}\text { Stand J } \\
\text { Basal area: } 32 \mathrm{~m}^{2} / \text { ha } \\
\text { Density: } 453 \text { stems/ ha }\end{array}$} \\
\hline \multicolumn{4}{|l|}{ species } \\
\hline $\begin{array}{l}\text { Acer saccharum } \\
\text { Fagus grandifolia } \\
\text { Quercus rubra } \\
\text { Betula lutea } \\
\text { Aesculus octandra } \\
\text { Fraxinus americana }\end{array}$ & $\begin{array}{l}58.4 \\
15.4 \\
12.4 \\
7.3 \\
3.3 \\
3.3\end{array}$ & $\begin{array}{r}56.2 \\
12.5 \\
16.2 \\
7.5 \\
3.7 \\
3.7\end{array}$ & $\begin{array}{r}60.6 \\
18.3 \\
8.4 \\
7.0 \\
2.8 \\
2.8\end{array}$ \\
\hline \multicolumn{4}{|l|}{$\begin{array}{l}\text { Stand } k \\
\text { Basal area: } 32.5 \mathrm{~m}^{2} / \mathrm{ha} \\
\text { Density: } 558 \text { stems } / \text { ha }\end{array}$} \\
\hline \multicolumn{4}{|l|}{ species } \\
\hline $\begin{array}{l}\text { Fagus grandifolia } \\
\text { Acer saccharum } \\
\text { Betula lutea } \\
\text { Aesculus octandra } \\
\text { Acer pensylvanicum } \\
\text { Amelanchier laevis } \\
\text { Hamamel is virginiana } \\
\text { Magnolia acuminata }\end{array}$ & $\begin{array}{r}63.5 \\
20.2 \\
6.7 \\
4.5 \\
2.1 \\
1.5 \\
.8 \\
.8\end{array}$ & $\begin{array}{r}58.8 \\
24.6 \\
7.7 \\
4.6 \\
- \\
1.5 \\
1.5 \\
1.5\end{array}$ & $\begin{array}{r}68.6 \\
15.7 \\
5.7 \\
4.3 \\
4.3 \\
1.4 \\
- \\
-\end{array}$ \\
\hline \multicolumn{4}{|l|}{$\begin{array}{l}\text { Stand L } \\
\text { Basal area: } 34 \mathrm{~m}^{2} / \mathrm{ha} \\
\text { Density: } 509 \text { stems/ha }\end{array}$} \\
\hline \multicolumn{4}{|l|}{ species } \\
\hline $\begin{array}{l}\text { Picea rubens } \\
\text { Betula lutea } \\
\text { Fagus grandifolia }\end{array}$ & $\begin{array}{r}84.5 \\
12.7 \\
2.9\end{array}$ & $\begin{array}{r}73.1 \\
21.2 \\
5.8\end{array}$ & $\begin{array}{r}95.8 \\
4.2 \\
-\end{array}$ \\
\hline \multicolumn{4}{|l|}{$\begin{array}{l}\text { Stand } M \\
\text { Basal area: } 27 \mathrm{~m}^{2} / \mathrm{ha} \\
\text { Density: } 414 \text { stems/ha }\end{array}$} \\
\hline \multicolumn{4}{|l|}{ species } \\
\hline $\begin{array}{l}\text { Quercus rubra } \\
\text { Acer saccharum } \\
\text { Aesculus octandra } \\
\text { Carya ovata } \\
\text { Betula lutea } \\
\text { Fraxinus americana }\end{array}$ & $\begin{array}{r}35.7 \\
33.1 \\
18.9 \\
6.6 \\
3.8 \\
1.9\end{array}$ & $\begin{array}{r}42.6 \\
27.8 \\
6.7 \\
7.4 \\
3.7 \\
1.9\end{array}$ & $\begin{array}{r}28.8 \\
38.4 \\
21.2 \\
5.8 \\
3.8 \\
1.9\end{array}$ \\
\hline
\end{tabular}

Continued 
Table 18 Continued

\begin{tabular}{lccc} 
& $\begin{array}{c}\text { Importance } \\
\text { value }\end{array}$ & $\begin{array}{c}\text { Dominance } \\
\text { (\%basal area) }\end{array}$ & Density $\left(\begin{array}{l}\alpha \\
\%\end{array}\right)$ \\
\hline Stand N & & & \\
Basal area: $38 \mathrm{~m}^{2} /$ ha & & & \\
Density: 57 stems/ha & & & \\
$\quad$ species & & 18.7 & 22.2 \\
Amelanchier laevis & 20.5 & 15.6 & 21.1 \\
Fagus grandifolia & 18.4 & 19.8 & 10.0 \\
Quercus rubra & 14.9 & 9.4 & 12.2 \\
Magnolia fraseri & 10.8 & 11.5 & 7.4 \\
Betula lenta & 8.0 & 8.3 & 6.7 \\
Quercus prinus & 7.5 & 5.2 & 6.7 \\
Acer rubrum & 7.5 & 2.1 & 6.7 \\
Magnolia acuminata & 5.9 & 1.0 & 1.1 \\
Acer saccharum & 4.4 & 1.0 & 1.1 \\
Betula lutea & 1.1 & & \\
Robinia pseudo-acacia & 1.1 & & \\
\hline
\end{tabular}

\begin{tabular}{|c|c|c|c|}
\hline \multicolumn{4}{|l|}{$\begin{array}{l}\text { Stand } 0 \\
\text { Basal area: } 36.8 \mathrm{~m}^{2} / \mathrm{ha} \\
\text { Density: } 731 \text { stems/ha }\end{array}$} \\
\hline species & . & & \\
\hline $\begin{array}{l}\text { Acer saccharum } \\
\text { Tilia heterophylla } \\
\text { Quercus rubra } \\
\text { Magnolia acuminata } \\
\text { Acer rubrum } \\
\text { Fraxinus americana } \\
\text { Robinia pseudo-acacia } \\
\text { Quercus prinus } \\
\text { Carya ovata } \\
\text { Prunus serotina } \\
\text { Carya glabra } \\
\text { Fagus grandifolia } \\
\text { Ostrya virginiana } \\
\text { Carya cordiformis } \\
\text { Amelanchier laevis } \\
\text { Aesculus octandra }\end{array}$ & $\begin{array}{r}33.0 \\
23.4 \\
8.9 \\
5.2 \\
4.0 \\
3.9 \\
3.9 \\
3.2 \\
2.5 \\
2.5 \\
2.1 \\
2.0 \\
2.0 \\
1.5 \\
1.0 \\
1.0\end{array}$ & $\begin{array}{r}30.4 \\
16.3 \\
10.9 \\
4.3 \\
5.4 \\
4.3 \\
4.3 \\
5.4 \\
3.3 \\
3.3 \\
3.3 \\
2.2 \\
2.2 \\
2.2 \\
1.1 \\
1.1\end{array}$ & $\begin{array}{r}35.7 \\
30.4 \\
7.0 \\
6.1 \\
2.6 \\
3.5 \\
3.5 \\
.9 \\
1.7 \\
1.7 \\
.9 \\
1.7 \\
1.7 \\
.9 \\
.9 \\
.9\end{array}$ \\
\hline \multicolumn{4}{|l|}{$\begin{array}{l}\text { Stand } P \\
\text { Basal area: } 31 \mathrm{~m}^{2} / \mathrm{ha} \\
\text { Density: } 501 \text { stems } / \text { ha }\end{array}$} \\
\hline \multicolumn{4}{|l|}{ species } \\
\hline $\begin{array}{l}\text { Fagus grandifolia } \\
\text { Acer saccharum } \\
\text { Betula lutea } \\
\text { Amelanchier laevis } \\
\text { Acer pensylvanicum } \\
\text { Picea rubens }\end{array}$ & $\begin{array}{r}60.0 \\
19.2 \\
13.7 \\
3.2 \\
2.4 \\
1.6\end{array}$ & $\begin{array}{r}54.8 \\
17.8 \\
21.0 \\
3.2 \\
1.6 \\
1.6\end{array}$ & $\begin{array}{r}65.1 \\
20.6 \\
6.3 \\
3.2 \\
3.2 \\
1.6\end{array}$ \\
\hline
\end{tabular}

Continued 
Table 18 Continued

Importance
value $\quad \begin{gathered}\text { Dominance } \\ \text { (\%basal area) }\end{gathered} \quad$ Density $(\%)$

\begin{tabular}{|c|c|c|c|}
\hline \multirow{2}{*}{\multicolumn{4}{|c|}{$\begin{array}{c}\text { Stand } 0 \\
\text { Basal area: } 31.5 \mathrm{~m}^{2} / \mathrm{ha} \\
\text { Density: } 502 \text { stems/ha } \\
\text { species }\end{array}$}} \\
\hline & & & \\
\hline $\begin{array}{l}\text { Fagus grandifolia } \\
\text { Acer saccharum } \\
\text { Prunus serotina } \\
\text { Betula lutea } \\
\text { Acer pensylvanicum } \\
\text { Acer spicatum } \\
\text { Aesculus octandra }\end{array}$ & $\begin{array}{r}42.1 \\
39.7 \\
7.1 \\
4.8 \\
4.0 \\
1.6 \\
.8\end{array}$ & $\begin{array}{r}39.7 \\
41.3 \\
5.8 \\
8.0 \\
3.2 \\
1.6 \\
1.6\end{array}$ & $\begin{array}{r}44.4 \\
38.1 \\
9.5 \\
1.6 \\
4.8 \\
1.6 \\
-\end{array}$ \\
\hline \multicolumn{4}{|l|}{$\begin{array}{l}\text { Stand } R \\
\text { Basal area: } 38.5 \mathrm{~m}^{2} / \mathrm{ha} \\
\text { Density: } 502 \text { stems/ha }\end{array}$} \\
\hline \multicolumn{4}{|l|}{ species } \\
\hline $\begin{array}{l}\text { Acer rubrum } \\
\text { Carya ovalis } \\
\text { Quercus prinus } \\
\text { Quercus rubra } \\
\text { Carya ovata } \\
\text { Betula lenta } \\
\text { Fraxinus americana } \\
\text { Quercus alba } \\
\text { Robinia pseudo-acacia } \\
\text { Magnolia acuminata } \\
\text { Betula lutea } \\
\text { Hamamelis virginiana } \\
\text { Nyssa sylvatica } \\
\text { Tilia heterophylla }\end{array}$ & $\begin{array}{r}32.5 \\
25.5 \\
11.1 \\
9.7 \\
4.0 \\
3.7 \\
3.5 \\
2.2 \\
2.2 \\
2.1 \\
1.4 \\
.6 \\
.6 \\
.6\end{array}$ & $\begin{array}{r}28.6 \\
20.8 \\
14.3 \\
13.0 \\
6.5 \\
2.6 \\
3.9 \\
1.3 \\
1.3 \\
2.6 \\
1.3 \\
1.3 \\
1.3 \\
1.3\end{array}$ & $\begin{array}{r}36.5 \\
30.2 \\
7.9 \\
6.3 \\
1.6 \\
4.8 \\
3.2 \\
3.2 \\
3.2 \\
1.6 \\
1.6 \\
- \\
- \\
-\end{array}$ \\
\hline \multicolumn{4}{|l|}{$\begin{array}{l}\text { Stand } \mathrm{S} \\
\text { Basal area: } 34 \mathrm{~m}^{2} / \mathrm{ha} \\
\text { Density: } 495 \mathrm{stems} / \mathrm{ha}\end{array}$} \\
\hline \multicolumn{4}{|l|}{ species } \\
\hline $\begin{array}{l}\text { Quercus rubra } \\
\text { Robinia pseudo-acacia } \\
\text { Acer saccharum } \\
\text { Aesculus octandra } \\
\text { Fraxinus americana } \\
\text { Acer rubrum } \\
\text { Carya ovalis } \\
\text { Carya ovata } \\
\text { Quercus prinus }\end{array}$ & $\begin{array}{r}36.5 \\
20.1 \\
15.9 \\
9.1 \\
6.2 \\
4.7 \\
4.5 \\
2.2 \\
.7\end{array}$ & $\begin{array}{r}34.3 \\
25.7 \\
15.7 \\
8.6 \\
4.3 \\
1.4 \\
5.7 \\
2.9 \\
1.4\end{array}$ & $\begin{array}{r}38.7 \\
14.5 \\
16.1 \\
9.7 \\
8.1 \\
8.1 \\
3.2 \\
1.6 \\
-\end{array}$ \\
\hline
\end{tabular}

Continued 
116.

Table 18 Continued

\begin{tabular}{|c|c|c|c|}
\hline & $\begin{array}{c}\text { Importance } \\
\text { value }\end{array}$ & $\begin{array}{c}\text { Dominance } \\
\text { (abasal area) }\end{array}$ & Density $\left(\begin{array}{l}\% \\
\%\end{array}\right)$ \\
\hline \multicolumn{4}{|l|}{$\begin{array}{l}\text { Stand } T \\
\text { Basal area: } 38.5 \mathrm{~m}^{2} / \text { ha } \\
\text { Density: } 495 \text { stems/ha }\end{array}$} \\
\hline species & & & \\
\hline $\begin{array}{l}\text { Fagus grandifolia } \\
\text { Picea rubens } \\
\text { Acer rubrum } \\
\text { Amelanchier laevis } \\
\text { Magnolia fraseri } \\
\text { Betula lutea } \\
\text { Quercus rubra } \\
\text { Acer saccharum } \\
\text { Prunus pensylvanica } \\
\text { Betula lenta } \\
\text { Prunus serotina } \\
\text { Acer pensylvanicum } \\
\text { Ostrya virginiana }\end{array}$ & $\begin{array}{r}43.9 \\
12.1 \\
10.4 \\
9.4 \\
5.8 \\
5.0 \\
3.4 \\
2.9 \\
2.9 \\
1.5 \\
1.5 \\
.6 \\
.6\end{array}$ & $\begin{array}{r}44.1 \\
6.5 \\
14.3 \\
9.1 \\
5.2 \\
5.2 \\
5.2 \\
2.6 \\
2.6 \\
1.3 \\
1.3 \\
1.3 \\
1.3\end{array}$ & $\begin{array}{r}43.5 \\
17.7 \\
6.5 \\
9.7 \\
6.5 \\
4.8 \\
1.6 \\
3.2 \\
3.2 \\
1.6 \\
1.6 \\
- \\
-\end{array}$ \\
\hline
\end{tabular}

Stand $V$

Basal area: $27.5 \mathrm{~m}^{2} / \mathrm{ha}$

Density: 463 stems/ha

species

\begin{tabular}{lrrr} 
Acer saccharum & 48.6 & 47.3 & 50.0 \\
Quercus rubra & 16.0 & 18.2 & 13.8 \\
Betula lenta & 8.9 & 9.1 & 8.6 \\
Acer pensylvanicum & 7.1 & 7.3 & 6.9 \\
Betula lutea & 7.0 & 5.5 & 8.6 \\
Acer rubrum & 7.0 & 5.5 & 8.6 \\
Amelanchier laevis & 4.4 & 3.6 & 5.2 \\
Fraxinus americana & 2.7 & 3.6 & 1.7 \\
\hline
\end{tabular}

Stand $Y$

Basal area: $51 \mathrm{~m}^{2} / \mathrm{ha}$

Density: 1337 stems/ha

species

$\begin{array}{lrrr}\text { Abies fraseri } & 77.9 & 78.4 & 77.4 \\ \text { Picea rubens } & 13.8 & 12.7 & 14.9 \\ \text { Sorbus americana } & 8.3 & 8.8 & 7.7\end{array}$

Stand $Z$

Basal area: $36 \mathrm{~m}^{2} / \mathrm{ha}$

Density: 542 stems/ha

species

Quercus rubra

Quercus prinus

Acer rubrum

Carya oval is

Fraxinus americana

Amelanchier laevis

Acer pensylvanicum

44.8
40.1
6.6
3.8
1.9
1.9
.9

42.6
35.2
9.3
5.6
1.9
3.7
1.9

47.1

45.1

3.9

2.0

2.0

.9

$\begin{array}{ll}3.7 & - \\ 1.9 & -\end{array}$


Table 19. Relative density data for saplings, larger seedlings, and smal1 seedlings, by stand.

\begin{tabular}{|c|c|c|c|}
\hline & Saplings (\%) & $\begin{array}{l}\text { Larger } \\
\text { seedlings }(\%)\end{array}$ & $\begin{array}{l}\text { Sma11 } \\
\text { seedlings (\%) }\end{array}$ \\
\hline \multicolumn{4}{|c|}{$\begin{array}{l}\text { Stand A } \\
\text { Total densities (stems/ha): } \\
\text { saplings - } 1081 \\
\text { larger seedlings }-1866 \\
\text { small seedlings }-4630 \\
\text { species }\end{array}$} \\
\hline $\begin{array}{l}\text { Acer saccharum } \\
\text { Fagus grandifolia } \\
\text { Acer pensylvanicum } \\
\text { Tilia heterophylla } \\
\text { Ostrya virginiana } \\
\text { Fraxinus americana } \\
\text { Aesculus octandra } \\
\text { Quercus rubra } \\
\text { Cornus alternifolia }\end{array}$ & $\begin{array}{r}62.7 \\
19.6 \\
5.9 \\
3.9 \\
3.9 \\
2.0 \\
2.0 \\
- \\
-\end{array}$ & $\begin{array}{c}10.2 \\
43.2 \\
22.7 \\
- \\
- \\
- \\
1.1 \\
22.7 \\
-\end{array}$ & $\begin{array}{r}18.0 \\
23.6 \\
30.3 \\
- \\
12.4 \\
9.0 \\
2.2 \\
- \\
4.5\end{array}$ \\
\hline \multicolumn{4}{|c|}{$\begin{array}{l}\text { Stand B } \\
\text { Total densities (stems/ha): } \\
\text { saplings }-2608 \\
\text { larger seedlings }-2100 \\
\text { small seedlings }-7479 \\
\text { species }\end{array}$} \\
\hline $\begin{array}{l}\text { Acer saccharum } \\
\text { Fagus grandifolia } \\
\text { Acer pensylvanicum } \\
\text { Betula lutea } \\
\text { Aesculus octandra } \\
\text { Ostrya virginiana } \\
\text { Betula lenta } \\
\text { Viburnum alnifolium } \\
\text { Quercus rubra } \\
\text { Prunus serotina } \\
\text { Magnolia acuminata } \\
\text { Fraxinus americana } \\
\text { Acer rubrum } \\
\text { Amelanchier laevis } \\
\text { Cornus alternifolia }\end{array}$ & $\begin{array}{c}48.8 \\
37.4 \\
8.1 \\
1.6 \\
1.6 \\
.8 \\
.8 \\
.8 \\
- \\
- \\
- \\
- \\
- \\
- \\
-\end{array}$ & $\begin{array}{c}48.5 \\
27.3 \\
23.2 \\
- \\
- \\
1.0 \\
- \\
- \\
- \\
- \\
- \\
- \\
- \\
-\end{array}$ & $\begin{array}{c}15.6 \\
7.1 \\
46.8 \\
- \\
1.4 \\
- \\
- \\
1.4 \\
4.3 \\
5.7 \\
1.4 \\
1.4 \\
2.8 \\
9.2 \\
2.8\end{array}$ \\
\hline \multicolumn{4}{|c|}{$\begin{array}{l}\text { Stand D } \\
\text { Total densities (stems/ha): } \\
\text { saplings }-2929 \\
\text { larger seedlings }-3772 \\
\text { small seedlings }-5315 \\
\text { species }\end{array}$} \\
\hline $\begin{array}{l}\text { Fagus grandifolia } \\
\text { Acer pensylvanicum } \\
\text { Acer saccharum } \\
\text { Aesculus octandra } \\
\text { Hamamel is virginiana } \\
\text { Ostrya virginiara }\end{array}$ & $\begin{array}{r}53.3 \\
30.4 \\
14.1 \\
1.1 \\
1.1 \\
-\end{array}$ & $\begin{array}{l}59.5 \\
28.7 \\
11.8 \\
- \\
- \\
-\end{array}$ & $\begin{array}{c}42.0 \\
21.8 \\
35.4 \\
- \\
- \\
1.9\end{array}$ \\
\hline
\end{tabular}

Continued 
Table 19 Continued

Stand $E$

Total densities (stems/ha):

saplings - 828

larger seedlings - 2085

small seedlings - 17029

species

Rhododendron maximum

Acer pensilivanicum

Fagus grandifolia

Picea rubens

Tsuga canadensis

Prunus serotina

Magnolia fraseri

Fraxinus americana

Betula lutea

Acer rubrum

Amelanchier laevis

Viburnum alnifolium

Ilex montana

50.0
30.8
15.4
3.9
-
$=$
-
-
-
-
-

1.5
89.3
-
7.6
-
-
-
-
-
-
-
1.5

6.1

42.1

$\begin{array}{ll}- & 1.9 \\ .6 & 2.8\end{array}$

-
-

12.6

2.8

$\begin{array}{ll}- & 7.9\end{array}$

$-\quad 15.9$

- 3.3

Stand $F$

Total densities (stems/ha):

saplings - 1720

larger seedlings - 4201

small seedlings - 8594

species

Acer spicatum

Picea rubens

Acer pensyivanicum

Betula lutea

Fagus grandifolia

Viburnum alnifolium

Cornus alternifolia

Sorbus americana

1.5

3. 3

Ribes glandulosum

$\begin{array}{crc}37.0 & 25.0 & 13.9 \\ 24.1 & 8.3 & - \\ 14.8 & 4.5 & 8.3 \\ 11.1 & .8 & - \\ 5.6 & .8 & - \\ 5.6 & 56.8 & 29.6 \\ 1.9 & 3.0 & 13.9 \\ - & .8 & - \\ - & - & 34.3\end{array}$

Stand $G$

Total densities (stems/ha):

saplings - 1242

larger seed ings - 3406

small seedlings - 5172

species

Picea rubens

Abies fraseri

Betula iutea

Ilex montana

Sorbus americana

Menziesia pilosa

Acer spicatum

Acer pensylvanicum

$\begin{array}{rr}66.7 & 8.4 \\ 20.5 & 91.6 \\ 7.7 & - \\ 5.1 & - \\ - & - \\ - & - \\ - & -\end{array}$

46.2

$-$

23.1

10.8

10.8
13.8

6.2

Continued 
Table 19 Continued

Stand $H$

Total densities (stems/ha):

saplings - 340

larger seedlings - 85

small seediings - 636

species

Acer saccharum

Aesculus octandra

Picea rubens

Fagus grandifolia

50.0

25.0

12.5

Abies fraseri

12.5

50.0
-
50.0

66.7

$-$

33.3

Stand J

Total densitie (stems/ha):

saplings - 1706

larger seedling - 1451.

small seedlings - 2356

species

Fagus grandifolia

Acer pensylvanicum

Acer saccharum

Aesculus octandra

Ilex montana

Prunus serotina

Crataegus (crus-galli?)

Acer rubrum

Sambucus pubens

Cornus alternifolia

34.3
31.3
22.4
10.5
1.5
-
-
$=$
$=$

21.1

21.1
8.8

45.6

5.3

10.5

5.2

$-$

1.8

1.8

24.3

10.8

54.1

$-$

5.4

5.4

$-$
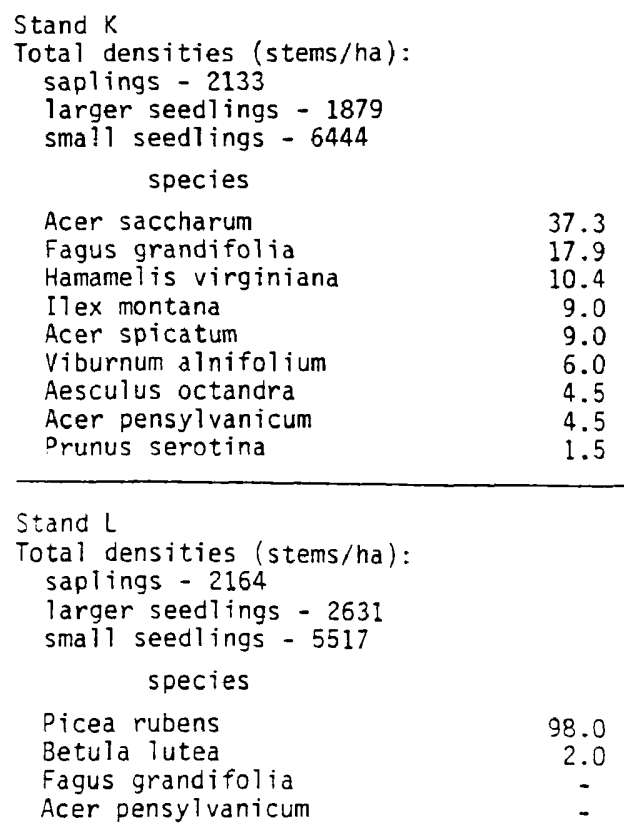

20.3

13.6

13.6

1.7

1.7

1.7

57.7

1.7

1.7

19.8

$-$

45.7

2.5

4.9

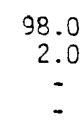

96.8

100.0

1.6

1.6 
Table 19 Continued

\begin{tabular}{|c|c|c|}
\hline Saplings $(x)$ & $\begin{array}{l}\text { Larger } \\
\text { seedlings (\%) }\end{array}$ & $\begin{array}{l}\text { Sinall } \\
\text { seedlings }\end{array}$ \\
\hline
\end{tabular}

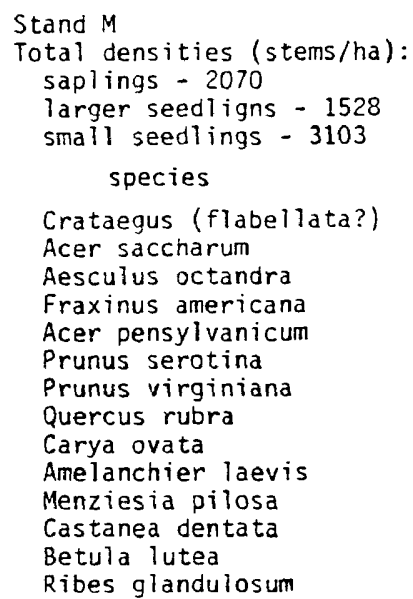

$\begin{array}{rrr}25.6 & 18.7 & 5.1 \\ 25.7 & 2.1 & 10.3 \\ 14.3 & 4.2 & 10.3 \\ 7.1 & 6.2 & - \\ 7.1 & - & - \\ 5.7 & 2.1 & - \\ 4.3 & 10.4 & - \\ 1.4 & 2.1 & - \\ 1.4 & - & - \\ 1.4 & - & - \\ 1.4 & - & - \\ 1.4 & 2.1 & - \\ - & 52.1 & 74.3\end{array}$

Stand $\mathrm{N}$

Total densities (stems/ha):

saplings - 3781

larger seedlings - 3302

small seedlings - 10759

species

Fagus grandifolia

Quercus rubra

Acer pensylvanicum

Magnolia fraseri

Hamamel is virginiana

Amelanchier laevis

Betula lenta

Robinia pseudo-acacia

Magnolia acuminata

Acer saccharum

Acer rubrum

Quercus prinus

Prunus serotina

Vaccinium vacillans

Smilax rotundifolia var. quadranguiaris

Menziesia pilosa

\begin{tabular}{rrr}
36.4 & & \\
36.0 & 35.5 & 9.5 \\
10.1 & 1.8 & 6.5 \\
7.4 & 27.8 & 22.5 \\
4.0 & 7.7 & 4.7 \\
2.0 & 4.1 & 4.7 \\
1.3 & - & 2.4 \\
.7 & 1.8 & 2.4 \\
.7 & - & - \\
.7 & - & 2.4 \\
.7 & 1.8 & 3.6 \\
- & - & 17.2 \\
- & - & 1.2 \\
- & 1.8 & 2.4 \\
- & & 2.4 \\
- & 17.8 & 14.2 \\
\hline
\end{tabular}

\section{Stand 0}

Total densities (stems/ha):

saplings - 1553

larger seediings - 2393

small seedlings - 4902

species

Acer saccharum

Ostrya virginiana

Aesculus octandra

Tilia heterophylla

Fagus grandifolia

Acer rubrum

Prunus serotina

Magnolia acuminata

Fraxinus americana

Carya ovata

Carya cordiformis

Amelanchier laevis

Cornus alternifolia

Castanea dentata

Acer pensylvanicum

\begin{tabular}{rrc}
72.1 & 54.3 & 59.7 \\
9.8 & 4.3 & 10.4 \\
8.2 & 3.2 & 7.8 \\
6.6 & 3.2 & - \\
1.6 & 7.4 & 2.6 \\
1.6 & - & - \\
- & 11.7 & 2.6 \\
- & 1.1 & 2.6 \\
- & 7.4 & 9.1 \\
- & 3.2 & - \\
- & 1.1 & - \\
- & -5 & - \\
- & 1.1 & 2.6 \\
- & -5 & - \\
\hline
\end{tabular}

Continued 
Table 19 Continued

Saplings (\%) Larger Small

seedlings $(\%)$ seedlings $(\%)$

\begin{tabular}{|c|c|c|c|}
\hline & Saplings (\%) & $\begin{array}{l}\text { Larger } \\
\text { seedlings }(\%)\end{array}$ & $\begin{array}{c}\text { Sma } 11 \\
\text { seedl ings }(\%)\end{array}$ \\
\hline \multicolumn{4}{|l|}{$\begin{array}{l}\text { Stand } P \\
\text { Total densities (stems/ha): } \\
\text { saplings }-2324 \\
\text { larger seedlings }-2196 \\
\text { small seedlings }-4933 \\
\text { species }\end{array}$} \\
\hline $\begin{array}{l}\text { Acer saccharum } \\
\text { Fagus grandifolia } \\
\text { Viburnum alnifolium } \\
\text { Acer pensylvanicum } \\
\text { Aesculus octandra } \\
\text { Cornus alternifolia }\end{array}$ & $\begin{array}{r}42.5 \\
38.4 \\
8.2 \\
8.2 \\
2.7 \\
-\end{array}$ & $\begin{array}{l}39.1 \\
14.5 \\
30.4 \\
14.5 \\
- \\
1.4\end{array}$ & $\begin{array}{r}17.7 \\
17.7 \\
51.6 \\
9.7 \\
3.2 \\
-\end{array}$ \\
\hline \multicolumn{4}{|l|}{$\begin{array}{l}\text { Stand } Q \\
\text { Total densities (stems/ha): } \\
\text { saplings }-1369 \\
\text { larger seedlings }-1305 \\
\text { small seedlings }-4216 \\
\text { species }\end{array}$} \\
\hline $\begin{array}{l}\text { Fagus grandifolia } \\
\text { Acer saccharum } \\
\text { Acer pensylvanicum } \\
\text { Betula lutea } \\
\text { Crataegus (crus-galli?) } \\
\text { Prunus serotina } \\
\text { Ribes rotundifolium } \\
\text { Cornus alternifolia } \\
\text { Acer spicatum }\end{array}$ & $\begin{array}{c}55.8 \\
23.3 \\
14.0 \\
4.7 \\
2.3 \\
= \\
= \\
-\end{array}$ & $\begin{array}{l}29.3 \\
17.1 \\
46.3 \\
- \\
- \\
- \\
= \\
7.3\end{array}$ & $\begin{array}{r}17.0 \\
3.8 \\
34.0 \\
3.8 \\
- \\
3.8 \\
13.2 \\
11.3 \\
13.2\end{array}$ \\
\hline
\end{tabular}

Stand $R$

Total densities (stems/ha):

saplings - 3980

larger seedlingd - 3690

small seedlings - 21401

species

Rhododendron calendulaceum

Magnolia acuminata

Acer rubrum

Hamamel is virginiana

Castanea dentata

Acer pensylvanicum

Quercus rubra

Fraxinus americana

Acer saccharum

Vaccinium corymbosum

Crataegus (fiabellata?)

Quercus alba

Prunus serotina

Nyssa sylvatica

Magnolia fraseri

Carya ovalis

Tilia heterophylla

Quercus prinus

Carya ovata

Amelanchier laevis

Vaccinium vacillans

Viburnum alnifolium

\begin{tabular}{rrr}
44.8 & 11.2 & 20.4 \\
8.8 & 26.7 & 13.4 \\
8.8 & 4.3 & 3.3 \\
8.8 & 2.6 & .7 \\
8.8 & 17.2 & 8.6 \\
7.2 & 7.8 & 4.8 \\
2.4 & 9.5 & 11.5 \\
1.6 & -.5 & .5 \\
1.6 & .9 & - \\
1.6 & .9 & - \\
1.6 & -.9 & .7 \\
.8 & .9 & - \\
.8 & 5.2 & .7 \\
.8 & .9 & 3.3 \\
.8 & .9 & 1.5 \\
.8 & - & 3.3 \\
- & - & - \\
- & 2.6 & .7 \\
- & 1.7 & 18.2 \\
- & - & 6.3 \\
\hline
\end{tabular}

Continued 
Table 19 Continued

$$
\begin{array}{lll}
\text { Saplings }(\%) & \begin{array}{c}
\text { Larger } \\
\text { seedlings }(\%)
\end{array} & \text { Small } \\
& \text { seedlings }(\%)
\end{array}
$$

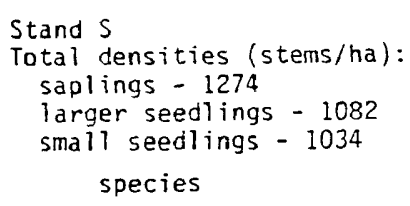

$\begin{array}{rr}62.5 & 52.9 \\ 17.5 & 17.6 \\ 7.5 & 2.9 \\ 5.0 & 2.9 \\ 2.5 & - \\ 2.5 & - \\ 2.5 & 14.7 \\ - & 2.9 \\ - & 2.9 \\ - & 2.9\end{array}$

53.8

15.4

2.9
.4

15.4

Stand $T$

Total densities (stems/ha):

saplings - 3658

larger seedlings - 3915

small seedlings - 10663

species

Fagus grandifolia

Acer pensylvanicum

Picea rubens

Viburnum alnifolium

Ostrya virginiana

Magnolia acuminata

Fraxinus americana

Betula lutea

Acer saccharum

Amelanchier laevis

Prunus serotina

Magnolia fraseri

Acer rubrum

Smilax rotundifolia var.

quadrangularis

$\begin{array}{rr}56.5 & 32 . \\ 33.0 & 52 . \\ 2.6 & 3 . \\ 2.6 & 5 . \\ .9 & - \\ .9 & - \\ .9 & - \\ .9 & 2 . \\ .9 & .8 \\ .9 & .8 \\ - & .8 \\ - & \end{array}$

32.5
52.8
3.2
5.7
-
-
-
-
2.4
.8
-
.8
.8
.8

29.5

22.0

$14 . \overline{4}$

$-$

$-$

3.0

1.5

3.5

22.0

Stand $V$

Total densities (stems/ha):

saplings - 2318

larger seedlings - 892

small seedlings - 2784

species

Acer rubrum

Acer pensylvanicum

Betula lenta

Acer saccharum

Tsuga canadens is

Amelanchier laevis

Castanea dentata

Quercus rubra

Betula iutea

$\begin{array}{rcc}68.5 & 71.4 & 37.1 \\ 16.7 & - & 25.7 \\ 5.6 & 7.1 & 5.7 \\ 3.7 & 21.4 & 20.0 \\ 1.9 & - & - \\ 1.9 & - & - \\ 1.9 & - & - \\ - & - & 5.7 \\ - & - & 5.7\end{array}$

Continued 
Table 19 Continued

$\begin{array}{lll}\text { Saplings }(\%) & \text { Larger } & \text { Small } \\ \text { seedlings }(\%) & \text { seedlings }(\%)\end{array}$

Stand $Y$

Total densities (stems/ha):

saplings - 828

larger seedlings - 732

small seedlings - 9310

species

Abies fraseri

Sorbus americana

Picea rubens

53.8

30.8

Amelanchier laevis

Ribes glandulosum

.15 .4

Leucothoe recurva

$-$

$-$

95.7
-
4.3
-
-
-

85.5

1.7

1.7

6.0

5.1

Stand $Z$

Total densities (stems/ha):

saplings - 2165

larger seedlings - 2675

small seedlings - 14549

$$
\text { species }
$$

Acer pensylvanicum

Rhododendron cal endulaceum

Quercus rubra

Acer rubrum

Amelanchier laevis

Carya ovalis

Ostrya virginiana

Castanea dentata

Quercus prinus

Betula lenta

Sassafras albjdum

Prunus serotina

Nyssa sylvatica

Magnolia acliminata

Fraxinus americana

Acer saccharum

Vaccinium vacillans

Vaccinium constablaei

$\begin{array}{rcr}45.1 & 28.6 & 11.6 \\ 11.8 & 12.7 & 7.5 \\ 9.8 & 11.1 & 19.7 \\ 7.8 & - & 7.5 \\ 7.8 & - & 6.1 \\ 5.9 & - & 4.1 \\ 3.9 & 11.1 & 1.4 \\ 3.9 & 11.1 & 6.1 \\ 2.0 & 7.9 & 2.7 \\ 2.0 & - & - \\ - & 3.2 & 1.4 \\ - & - & 1.4 \\ - & - & 1.4 \\ - & - & 1.4 \\ - & 1.6 & - \\ - & 4.8 & 2.7 \\ - & - & 25.2 \\ - & 7.9 & -\end{array}$


Table 20. Herbaceous coverage, frequency, and maximum coverage data, by stand. Species with less than $1 \%$ coverage denoted by an " $X$ ", while those which are present in the stand, but but were not located in a sample plot are denoted by a "-".

\begin{tabular}{|c|c|c|c|}
\hline & Coverage $(\%)$ & Frequency $(\%)$ & $\begin{array}{l}\text { Maximum } \\
\text { Coverage }(\%)\end{array}$ \\
\hline \multicolumn{4}{|l|}{$\begin{array}{l}\text { Stand A } \\
\text { species }\end{array}$} \\
\hline $\begin{array}{l}\text { Asarum canadense } \\
\text { Caulophyllum thalictroides } \\
\text { Viola canadensis } \\
\text { Trillium erectum } \\
\text { Disporum lanuginosum } \\
\text { Hydrophyllum canadense } \\
\text { Polygonatum biflorum } \\
\text { Laportea canadense } \\
\text { Dryopteris campyloptera } \\
\text { Hydrophyllum virginianum } \\
\text { Anemone quinquefolia } \\
\text { Cimicifuga racemosa } \\
\text { Prenanthes altissima } \\
\text { Osmunda cinnamomea } \\
\text { Polystichum achrostichoides } \\
\text { Botrychium virginianum } \\
\text { Dryopteris goldiana } \\
\text { Impatiens spp. } \\
\text { Arisaema triphyllum } \\
\text { Festuca obtusa } \\
\text { Carex aestivalis } \\
\text { Galium triflorum } \\
\text { Actaea pachypoda } \\
\text { Allium tricoccum } \\
\text { Dicentra canadensis } \\
\text { Podophyllum peltatum } \\
\text { Smilacina racemosa } \\
\text { Viola blanda }\end{array}$ & $\begin{array}{r}15.75 \\
12.50 \\
5.75 \\
7.00 \\
6.25 \\
6.75 \\
2.50 \\
1.50 \\
4.50 \\
4.00 \\
2.00 \\
3.00 \\
3.00 \\
.75 \\
1.75 \\
.50 \\
.50 \\
.50 \\
.25 \\
.25 \\
x \\
x \\
- \\
- \\
- \\
- \\
- \\
-\end{array}$ & $\begin{array}{l}60.0 \\
30.0 \\
80.0 \\
50.0 \\
50.0 \\
30.0 \\
60.0 \\
60.0 \\
30.0 \\
20.0 \\
30.0 \\
20.0 \\
20.0 \\
30.0 \\
20.0 \\
20.0 \\
20.0 \\
20.0 \\
10.0 \\
10.0 \\
10.0 \\
10.0 \\
- \\
- \\
- \\
- \\
- \\
-\end{array}$ & $\begin{array}{r}62.5 \\
85.0 \\
15.0 \\
37.5 \\
15.0 \\
37.5 \\
15.0 \\
2.5 \\
15.0 \\
37.5 \\
15.0 \\
15.0 \\
15.0 \\
2.5 \\
15.0 \\
2.5 \\
2.5 \\
2.5 \\
2.5 \\
2.5 \\
x \\
X \\
- \\
- \\
- \\
- \\
- \\
-\end{array}$ \\
\hline
\end{tabular}


Table 20 Continued

$$
\text { Coverage (\%) Frequency (\%) } \begin{gathered}
\text { Maximum } \\
\text { Coverage (\%) }
\end{gathered}
$$

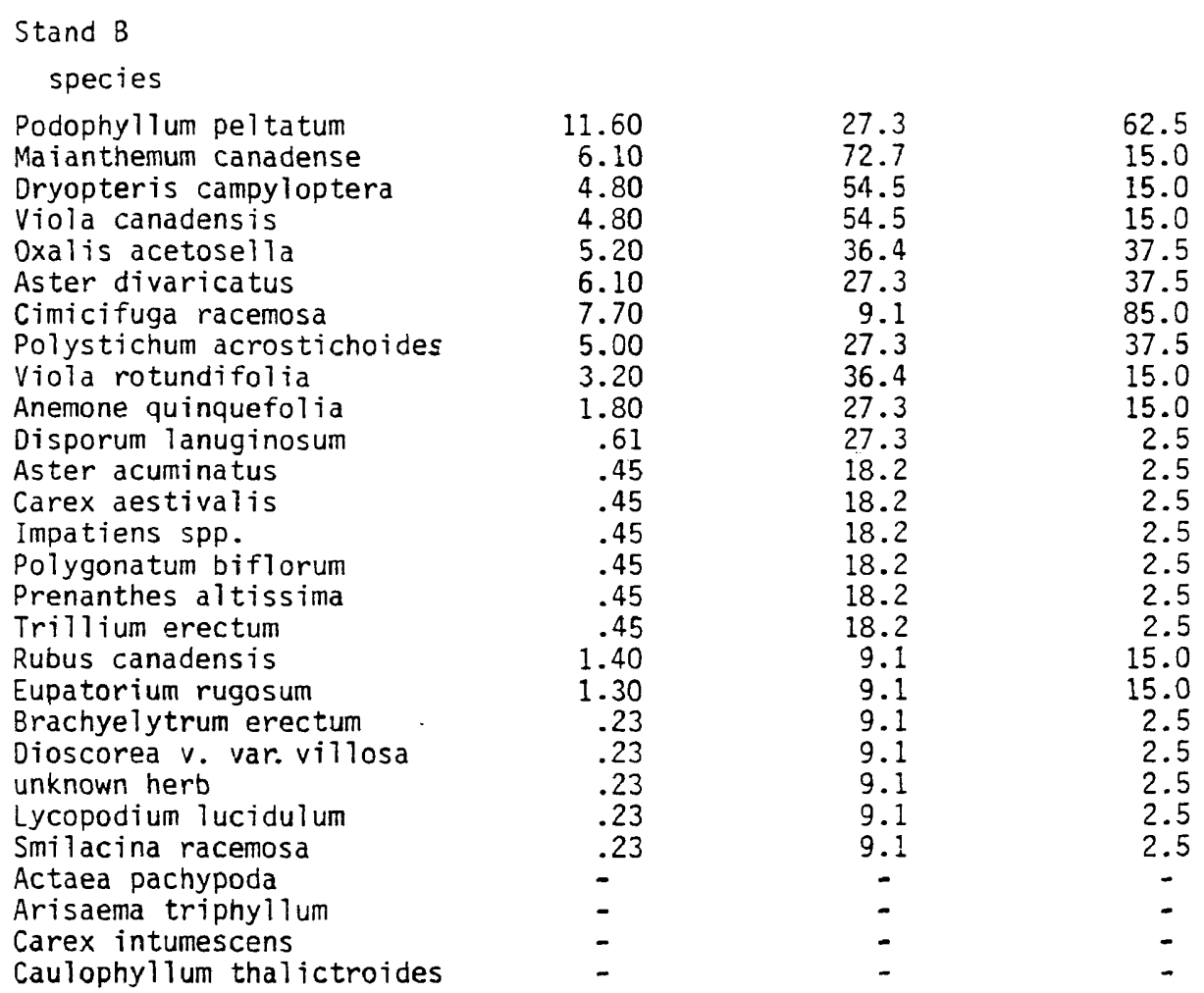

Stand D

species

Oxal is acetosella $\quad 35.00$

Thelypteris noveboracens is $\quad 13.50$

Eupatorium rugosum

13.50
7.25

Dryopteris campyloptera $\quad 3.50$

Rubus canadensis $\quad 4.00$

Trillium erectum $\quad .50$

Anemone quinquefolia $\quad 2.00$

Maianthemum canadense $\quad 2.00$

Viola blanda

Carex debilis

Festuca obtusa

.00
.75

3.75

Arisaema triphyllum

Cinna latifolia

Smilacina racemosa

Epifagus virginiana

Clintonia borealis

Dioscorea v. var. villosa

Thelypteris hexanoptera

$\begin{array}{cr}90.0 & 62.5 \\ 60.0 & 62.5 \\ 50.0 & 62.5 \\ 40.0 & 15.0 \\ 20.0 & 37.5 \\ 40.0 & 2.5 \\ 30.0 & 15.0 \\ 30.0 & 15.0 \\ 30.0 & 2.5 \\ 10.0 & 37.5 \\ 20.0 & 2.5 \\ 10.0 & 2.5 \\ 10.0 & 2.5 \\ 10.0 & 2.5 \\ 10.0 & x \\ - & - \\ - & - \\ - & -\end{array}$

Continued 
Table 20 Continued

$$
\text { Coverage }(\%) \quad \text { Frequency }(\%) \quad \begin{gathered}
\text { Maximum } \\
\text { Coverage }(\%)
\end{gathered}
$$

\begin{tabular}{|c|c|c|c|}
\hline \multicolumn{4}{|l|}{$\begin{array}{l}\text { Stand } E \\
\text { species }\end{array}$} \\
\hline $\begin{array}{l}\text { Oxalis acetosella } \\
\text { Rubus canadensis } \\
\text { Dryopteris campyloptera } \\
\text { Mitchella repens } \\
\text { Lycopodiun lucidulum }\end{array}$ & $\begin{array}{l}5.00 \\
4.64 \\
.71 \\
.71 \\
.36\end{array}$ & $\begin{array}{l}57.1 \\
42.8 \\
28.6 \\
28.6 \\
14.3\end{array}$ & $\begin{array}{r}15.0 \\
15.0 \\
2.5 \\
2.5 \\
2.5\end{array}$ \\
\hline \multicolumn{4}{|l|}{$\begin{array}{l}\text { Stand } F \\
\text { species }\end{array}$} \\
\hline $\begin{array}{l}\text { Oxalis acetosella } \\
\text { Dryopteris campyloptera } \\
\text { Rubus canadensis } \\
\text { Podophyl lum peltatum } \\
\text { Aster acuminatus } \\
\text { Lycopodium lucidulum } \\
\text { Tiarella cordifolia } \\
\text { Arisaema triphyllum }\end{array}$ & $\begin{array}{l}49.64 \\
25.71 \\
17.50 \\
5.00 \\
4.64 \\
.71 \\
-\end{array}$ & $\begin{array}{r}100.0 \\
100.0 \\
28.0 \\
57.1 \\
42.9 \\
28.6 \\
- \\
-\end{array}$ & $\begin{array}{r}85.0 \\
37.5 \\
85.0 \\
15.0 \\
15.0 \\
2.5 \\
- \\
-\end{array}$ \\
\hline \multicolumn{4}{|l|}{$\begin{array}{l}\text { Stand G } \\
\text { species }\end{array}$} \\
\hline $\begin{array}{l}\text { Oxal is acetosella } \\
\text { Oryopteris campyloptera } \\
\text { Aster acuminatus } \\
\text { Carex intumescens } \\
\text { Lycopodium lucidulum } \\
\text { Arisaema triphyllum } \\
\text { Eupatorium rugosum } \\
\text { Rubus canadensis } \\
\text { ilaianthemum canadense }\end{array}$ & $\begin{array}{r}60.00 \\
20.63 \\
4.38 \\
11.25 \\
4.06 \\
1.88 \\
1.88 \\
.63\end{array}$ & $\begin{array}{r}100.0 \\
50.0 \\
62.5 \\
37.5 \\
50.0 \\
25.0 \\
25.0 \\
25.0 \\
-\end{array}$ & $\begin{array}{r}85.0 \\
62.5 \\
2.5 \\
85.0 \\
15.0 \\
15.0 \\
15.0 \\
2.5 \\
-\end{array}$ \\
\hline \multicolumn{4}{|l|}{$\begin{array}{l}\text { Stand } H \\
\text { species }\end{array}$} \\
\hline $\begin{array}{l}\text { Dryopteris campyloptera } \\
\text { Eupatorium rugosum } \\
\text { Oxalis acetosella } \\
\text { Aster divaricatus } \\
\text { Anemone quinquefolia } \\
\text { Caulophyllum thalictroides } \\
\text { Aster acuminatus } \\
\text { Carex aestivalis } \\
\text { Carex intumescens } \\
\text { Viola blanda } \\
\text { Festuca obtusa } \\
\text { Arisaema triphyllum } \\
\text { Circaea alpina } \\
\text { Thelypteris noveboracensis } \\
\text { Rubus canadensis } \\
\text { Cinna latifolia } \\
\text { Hydrophyllum virginianum } \\
\text { Maianthemum canadense }\end{array}$ & $\begin{array}{r}38.0 \\
18.0 \\
15.5 \\
13.5 \\
2.0 \\
7.5 \\
3.0 \\
1.0 \\
1.0 \\
1.0 \\
3.0 \\
.5 \\
.5 \\
.5 \\
.5 \\
- \\
- \\
-\end{array}$ & $\begin{array}{r}100.0 \\
60.0 \\
60.0 \\
60.0 \\
80.0 \\
20.0 \\
40.0 \\
40.0 \\
40.0 \\
40.0 \\
20.0 \\
20.0 \\
20.0 \\
20.0 \\
20.0 \\
- \\
- \\
-\end{array}$ & $\begin{array}{r}85.0 \\
37.5 \\
37.5 \\
62.5 \\
2.5 \\
37.5 \\
15.0 \\
2.5 \\
2.5 \\
2.5 \\
15.0 \\
2.5 \\
2.5 \\
2.5 \\
2.5 \\
- \\
- \\
-\end{array}$ \\
\hline
\end{tabular}

Continued 
Table 20 Continued

$$
\text { Coverage (\%) Frequency }(\%) \quad \begin{gathered}
\text { Maximum } \\
\text { Coverage }(\%)
\end{gathered}
$$

\section{Stand $\mathrm{J}$}

species

Athyrium asplenioides

Trautvettaria carolinens is

Podophyllum peltatum

Rubus canadensis

Trillium erectum

Eupatorium rugosum

Viola blanda

Tiarella cordifoila

Festuca obtusa

Ellisia nyctelea

Arisaema triphyllum

Polygonatum biflorum

Cimicifuga racemosa

Disporum lanuginosum

Osmunda cinnamomea

A1lium tricoccum

Galium triflorum

Hydrophyllum virginianum

Impatiens spp.

Actaea pachypoda

Anemone quinquefolia

Carex pensylvanicum

Lycopodium lucidulum

Maianthemum canadense

Viola affinis

$\begin{array}{rrr}22.50 & 70.0 & 15.0 \\ 6.38 & 70.0 & 37.5 \\ 9.44 & 40.0 & 37.5 \\ 7.50 & 30.0 & 37.5 \\ 2.50 & 40.0 & 37.5 \\ 3.61 & 30.0 & 15.0 \\ 1.11 & 40.0 & 2.5 \\ .55 & 40.0 & 2.5 \\ .83 & 30.0 & 2.5 \\ 1.11 & 20.0 & 2.5 \\ .55 & 20.0 & 2.5 \\ .55 & 20.0 & 2.5 \\ 1.67 & 10.0 & 15.0 \\ 1.67 & 10.0 & 15.0 \\ 1.67 & 10.0 & 15.0 \\ .28 & 10.0 & 2.5 \\ .28 & 10.0 & 2.5 \\ .28 & 10.0 & 2.5 \\ .28 & 10.0 & 2.5 \\ .27 & 10.0 & 2.5 \\ .27 & 10.0 & 2.5 \\ - & - & - \\ - & - & - \\ - & - & - \\ - & - & -\end{array}$

Stand $L$

species

$\begin{array}{lrrr}\text { Dryopteris campyloptera } & 35.00 & 100.0 & 62.5 \\ \text { Thelypteris noveboracensis } & 21.20 & 25.0 & 85.0 \\ \text { Maianthemum canadense } & 5.00 & 75.0 & 15.0 \\ \text { Rubus canadensis } & 10.00 & 50.0 & 37.5 \\ \text { Oxalis acetosella } & 15.62 & 25.0 & 62.5 \\ \text { Carex intumescens } & .62 & 25.0 & 2.5 \\ \text { Carex pensylvanica } & .62 & 25.0 & 2.5\end{array}$

Stand $M$

species

Laportea canadensis

Hydrophyllum virginianum

Carex pensylvanica

Arisaema triphyllum

Impatiens spp.

Rubus canadensis

Festuca obtusa

Caulophyll um thalictroides

25.0

2.5

2.5

Aster acuminatus

Eupatorium rugosum

Thaspium barbinode

Osmorhiza claytonii

Polystichum acrostichoides

Dioscorea v. var. villosa

Thal ictrum polygamum

Uvularia perfoliatum

Viola affinis

Galium triflorum

Geranium maculatum

Trillium undulatum

$\begin{array}{rrr}36.43 & 100.0 & 62.5 \\ 6.79 & 71.4 & 37.5 \\ 9.64 & 42.9 & 62.5 \\ 3.21 & 57.1 & 15.0 \\ 3.21 & 57.1 & 15.0 \\ 5.70 & 28.6 & 37.5 \\ 1.43 & 57.1 & 2.5 \\ 5.36 & 14.3 & 37.5 \\ 2.50 & 28.6 & 15.0 \\ 2.50 & 28.6 & 15.0 \\ 2.50 & 28.6 & 15.0 \\ 2.14 & 14.3 & 15.0 \\ 2.14 & 14.3 & 15.0 \\ .36 & 14.3 & 2.5 \\ .36 & 14.3 & 2.5 \\ .36 & 14.3 & 2.5 \\ .36 & 14.3 & 2.5 \\ - & - & - \\ - & - & - \\ - & - & -\end{array}$

62.5

62.5
15.0

15.0

37.5

2.5

15.0

15.0

15.0

5.0

2.5

2.5

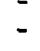

Continued 
Table 20 Continued

$$
\text { Coverage (\%) Frequency (\%) } \begin{gathered}
\text { Maximum } \\
\text { Coverage (\%) }
\end{gathered}
$$

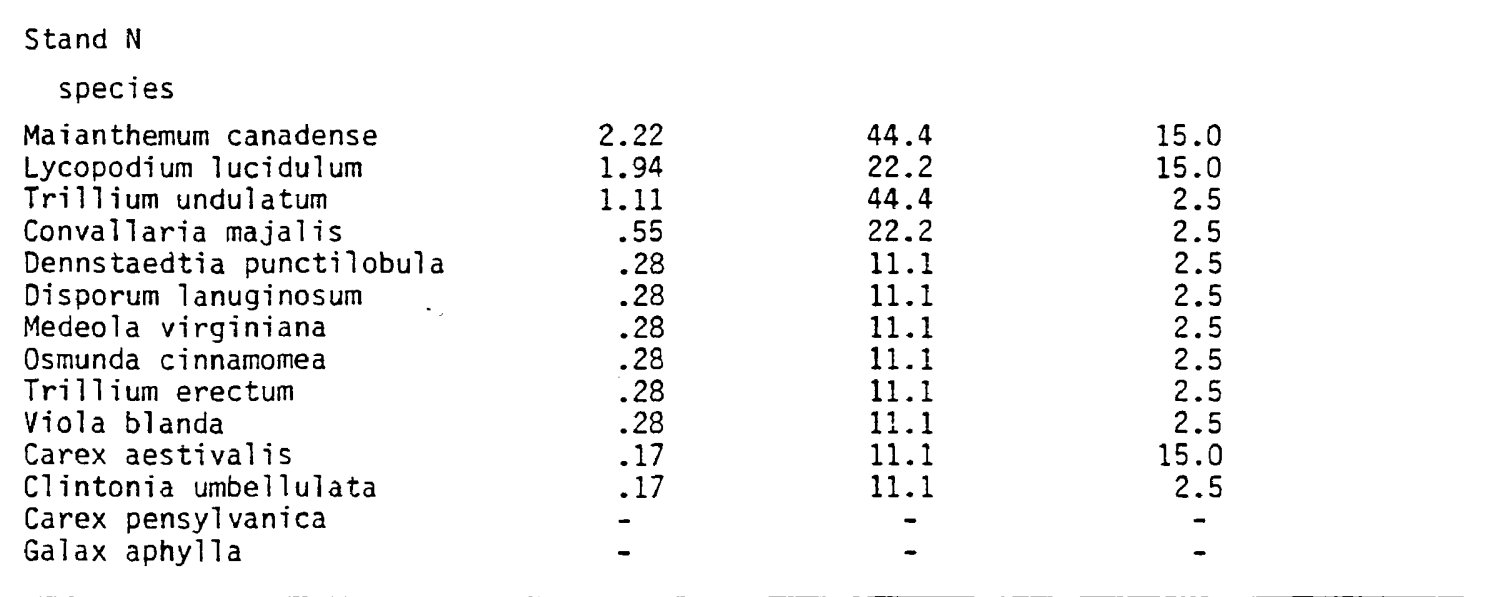

Stand 0

species

Aristolochia macrophylla

17.19

8.44

6.87

5.62

Thal ictrum polygamum

Uvularia perfoliata

Sanguinaria canadensis

Aster acuminatus

Circaea alpina

Impatiens spp.

Zizia aptera

Disporum lanuginosum

Trillium erectum

Arisaema triphyllum

Viola affinis

Cimicifuga racemosa

Parthenocissus quinquefolia

Polystichum acrostichoides

Galium triflorum

Viola canadensis

Botrychium virginianum

Caulophyllum thalictroides

Cryptotaenia canadense

Thelypteris noveboracens is

Hydrophyllum virginianum

Medeola virginiana

Osmunda cinnamomea

Poa cuspidata

Polygonatum biflorum

unknown rosette

Smilacina racemosa

Solidago curtisij

Lilium superbum
3.12

2.50

2.50

2.50

2.50

1.20

2.19

.94

.31

1.87

1.87

1.87

.62

62

.31

.31

31

.31

.31

.31

.31

.31

.31

.31

.31
62.5

37.5

37.5

50.0

62.5

37.5

37.5

37.5

37.5

50.0

25.0

37.5

37.5

12.5

12.5

12.5

25.0

25.0

12.5

12.5

12.5

12.5

12.5

12.5

12.5

12.5

12.5

12.5

12.5

12.5
62.5

37.7

37.5

37.5

15.0

15.0

15.0

15.0

15.0

2.5

15.0

2.5

2.5

15.0

15.0

15.0

2.5

2.5

2.5

2.5

2.5

2.5

2.5

2.5

2.5

2.5

2.5

2.5

2.5

2.5

Continued 
Table 20 Continued

$$
\text { Coverage (\%) Frequency }(\%) \quad \begin{gathered}
\text { Maximum } \\
\text { coverage }(\%)
\end{gathered}
$$

Stand $P$

species

Carex pensylvanica

Rubus canadensis

Aster acuminatus

Brachyelytrum erectum

Viola blanda

Disporum lanuginosum

Eupatorium rugosum

Arisaema triphyllum

Caulophyllum thalictroides

Thelypteris noveboracens is

Maianthemum canadense

Trillium erectum

Allium tricoccum

Aster divaricatus

Carex intumescens

Lycopodium lucidulum

Poa cuspidata

Smilacina racemosa

Solidago curtissii
Athyrium aspenioides

$\begin{array}{rrr}53.21 & 85.7 & 100.0 \\ 13.21 & 42.9 & 85.0 \\ 12.86 & 42.9 & 37.5 \\ 1.79 & 71.4 & 2.5 \\ 1.07 & 42.9 & 2.5 \\ 1.07 & 42.9 & 2.5 \\ .71 & 28.6 & 2.5 \\ .71 & 28.6 & 2.5 \\ .36 & 14.3 & 2.5 \\ .36 & 14.3 & 2.5 \\ .36 & 14.3 & 2.5 \\ .36 & 14.3 & 2.5 \\ .36 & 14.3 & 2.5 \\ - & - & - \\ - & - & - \\ - & - & - \\ - & - & - \\ - & - & - \\ - & - & - \\ - & - & -\end{array}$

Stand $Q$

species

Rubus canadensis

Eupatorium rugosum

Aster divaricatus

Impatiens spp.

Athyrium asplenioides

Brachyeiytrum erectum

Dryopteris campyloptera

Arisaema triphyllum

Solidago curtissii

Viola blanda

Allium tricoccum

Cimicifuga racemosa

Hydrophyllum virginianum

Polystichum acrostichoides

71.4
85.7
57.1
71.4
42.3
57.1
28.6
14.3
14.3
14.3
-
-
-
-

85.0

62.5

15.0

2.5

15.0

2.5

2.5

2.5

2.5

2.5

$-$

Continued 
Table 20 Continued

$$
\text { Coverage }(\%) \quad \text { Frequency }(\%) \quad \begin{gathered}
\text { Maximun } \\
\text { Coverage }(\%)
\end{gathered}
$$

Stand R

species

The lypteris noveboracens is

Osmunda cinnamomea

Aster divaricatus

Cimicifuga racemosa

Solidago curtissii

Eupatorium maculatum

Pteridium aquilinum

Thalictrum polygamum

Dioscorea v. var. villosa

Gal ium triflorum

Pedicularis canadens is

Prenanthes altissima

Sanguinaria canadensis

Viola affinis

Zizia aptera

Arisaema triphyllum

Aster lateriflorus

Carex aestivalis

Dryopteris campyloptera

Goodyera pubescens

Poa cuspidata

Uvularia perfoliata

Waldsteinia fragarioides

Carex pensylvanica

Chimaphila maculata

Circaea lutetiana

Clintonia umbellulata

Disporum lanuginosum

Gentiana decora

Hieracium paniculatum

Lycopodium obscurum

Medeola virginiana

Solidago glomerata

Stand S

species

Impatiens spp.

Laportea canadens is

11.25

11.25

1.25
1.25

1.25

.94

1.87

1.87

.62

.62

.62

.62

.62

.62

.62

.31

.31

.31

.31

.31

.31

$-$

-

$-$

Cimicifuga racemosa

Smilacina racemosa

Viola blanda

Arisaema triphyllum

Uvularia perfoliata

Aster divaricatus

Carex pensylvanica

Cacalia muhlenbergi

Disporum lanuginosum

Geranium maculatum

Hydrophyllum virginianum

Poa cuspidata

Polystichum acrosticnoides

unknown rosette

Sanguinaria canadensis

Clintonia umbellulata

Lilium superbum

Polygonatum biflorum

Trilitium erectum

Trillium undulatum

$\begin{array}{rrr}12.50 & 87.5 & 37.5 \\ 12.50 & 75.0 & 62.5 \\ 13.12 & 50.0 & 85.0 \\ 10.00 & 50.0 & 37.5 \\ .93 & 37.5 & 2.5 \\ .62 & 25.0 & 2.5 \\ .62 & 25.0 & 2.5 \\ .87 & 12.5 & 15.0 \\ .87 & 12.5 & 15.0 \\ .31 & 12.5 & 2.5 \\ .31 & 12.5 & 2.5 \\ .31 & 12.5 & 2.5 \\ .31 & 12.5 & 2.5 \\ .31 & 12.5 & 2.5 \\ .31 & 12.5 & 2.5 \\ .31 & 12.5 & 2.5 \\ .31 & 12.5 & 2.5 \\ - & - & - \\ - & - & - \\ - & - & - \\ - & - & -\end{array}$

Continued 
131.

Table 20 Continued

$$
\text { Coverage }(\%) \quad \text { Frequency }(\%) \quad \begin{gathered}
\text { Maximum } \\
\text { Coverage }(\%)
\end{gathered}
$$

Stand T

species

$\begin{array}{lrrr}\text { Aster acuminatus } & 22.50 & 85.7 & 37.5 \\ \text { Maianthemum canadense } & 1.79 & 71.4 & 2.5 \\ \text { Lycopodium ludidulum } & 3.21 & 57.1 & 15.0 \\ \text { Viola blanda } & 2.14 & 14.3 & 15.0 \\ \text { Arisaema triphyllum } & .36 & 14.3 & 2.5 \\ \text { Clintonia borealis } & .36 & 14.3 & 2.5 \\ \text { Mitchella repens } & .36 & 14.3 & - \\ \text { Carex pensylvanica } & - & - & - \\ \text { Thelypteris noveboracensis } & - & - & - \\ \text { Epifagus virginiana } & - & - & - \\ \text { Osmunda cinnamomea } & - & & \end{array}$

Stand $V$

species

Oryopteris campyloptera

32.86

9.29

5.36

Aster acuminatus

Athyrium asplenioides

Osmunda cinnamomea

Disporum lanuginosum

Lysimachia quadrifolia

Rubus canadensis

Viola rotundifolia

Thelypteris noveboracens is

Brachyelytrum erectum

Anemone quinquefolia

Arisaema triphyllum

Convallaria majal is

Lycopodium lucidulum

Medeola virginiana

Podophyllum peltatum

Prenanthes altissima

Dioscorea v. var. villosa

Lilium superbum

Lycopodium obscurum
5.71

2.86

.71

.71

.71

.71

2.14

2.10

.36

.36

.36

.36

.36

.36

.36

$-$

$-$
62.5

15.0

15.0

37.5

15.0

2.5

2.5

2.5

2.5

15.0

15.0

2.5

2.5

2.5

2.5

2.5

$\begin{array}{ll}14.3 & 2.5 \\ 14.3 & 2.5\end{array}$

$\begin{array}{ll}14.3 & 2.5 \\ 14.3 & 2.5\end{array}$

$-$

\section{Stand $Y$}

species

Oxal is acetosella

Dryopteris campyloptera

Aster acuminatus

Clintonia boreal is

Lycopodium lucidulum

Polystichum acrostichoides

78.57
11.79
$x$
-
-
-

85.0

62.5

14.3

14.3

$-$ 
Table 20 Continued

Coverage $(\%) \quad$ Frequency $(\%) \quad \begin{gathered}\text { Maximum } \\ \text { Coverage }(\%)\end{gathered}$

Stand Z

species

Aureolaria laevigata

Coreops is major

Solidago patula

Aster divaricatus

Hieracium paniculatum

Melampyrum 7 ineare

Poa cuspidata

Solidago curtissij

Aralia nudicaul is

Chimaphila maculata

Convallaria majalis

Dioscorea v. var. villosa

Disporum lanuginosum

Gentiana decora

Festuca obtusa

Prenanthes altissima

$\begin{array}{ccc}3.0 & 20.0 & 15.0 \\ 3.0 & 20.0 & 15.0 \\ 3.0 & 20.0 & 15.0 \\ .5 & 20.0 & 2.5 \\ .5 & 20.0 & 2.5 \\ .5 & 20.0 & 2.5 \\ .5 & 20.0 & 2.5 \\ X & - & x \\ - & - & - \\ - & - & - \\ - & - & - \\ - & - & - \\ - & - & - \\ - & - & - \\ - & - & - \\ - & - & -\end{array}$


133.

Table 21. Ordination axis values for listed and sample stands.

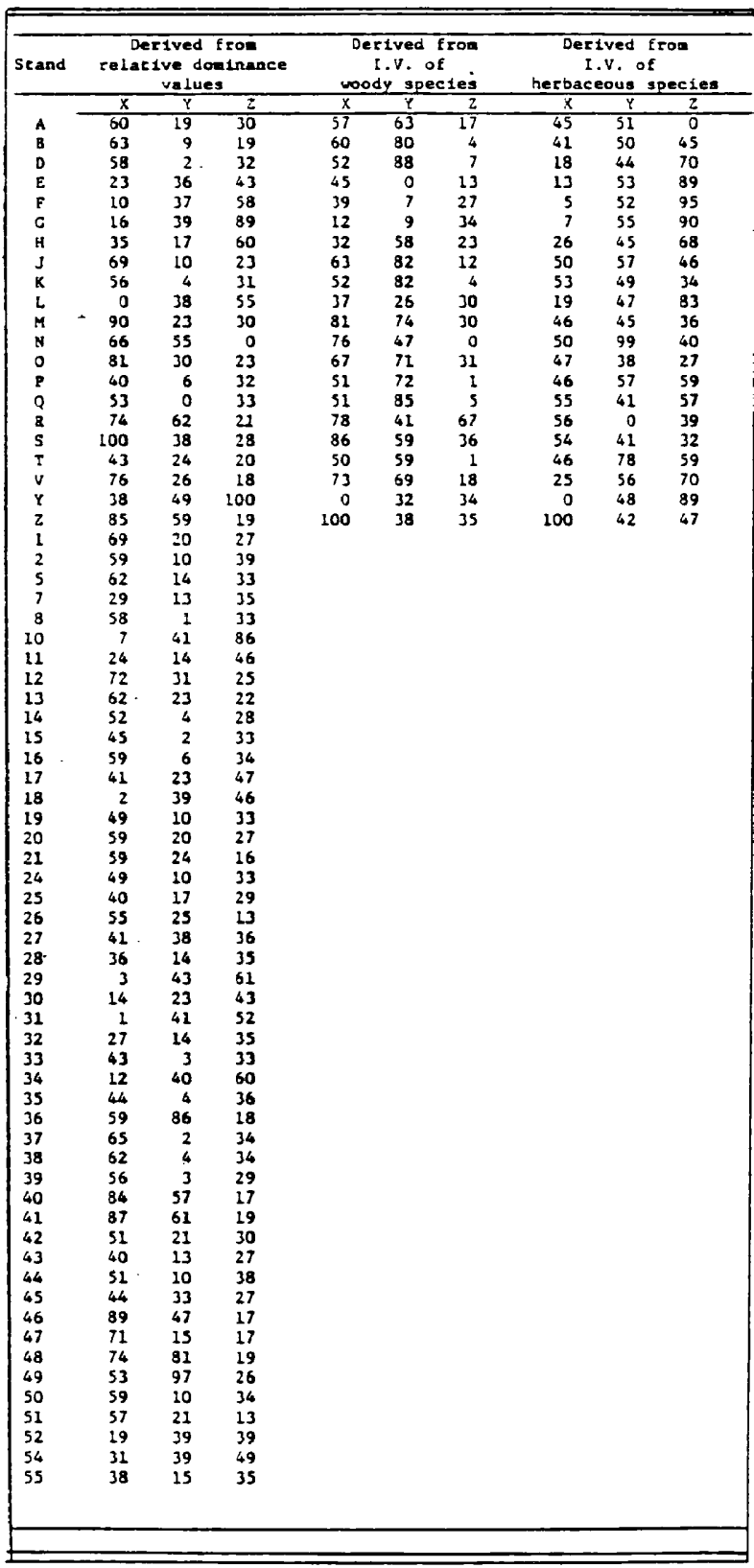




\begin{tabular}{|c|c|}
\hline 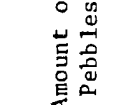 & $\sim 11, N M 0000-11$ \\
\hline$x^{m}$ & 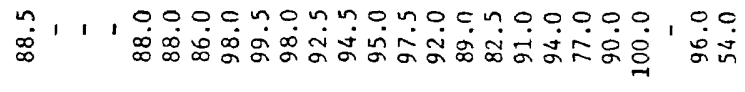 \\
\hline 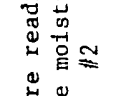 & 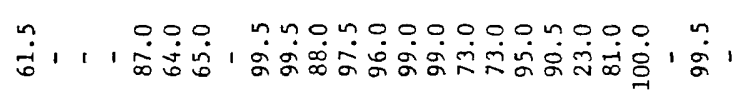 \\
\hline 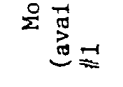 & 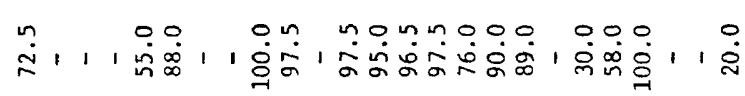 \\
\hline$\frac{5}{2}$ & 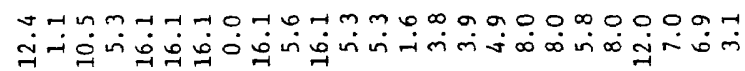 \\
\hline 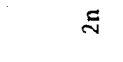 & 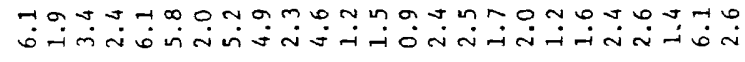 \\
\hline$\sum_{\substack{i \\
2}}^{m}$ & 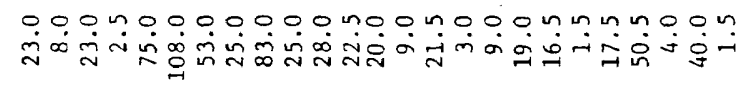 \\
\hline 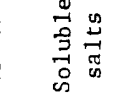 & 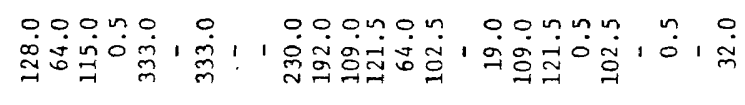 \\
\hline 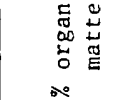 & 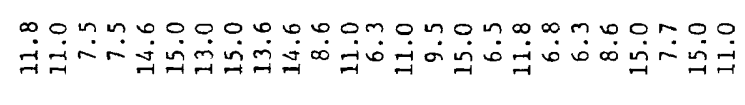 \\
\hline 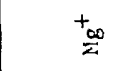 & 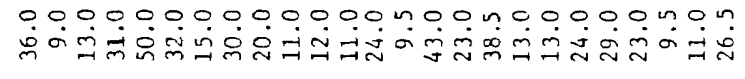 \\
\hline$+_{\widetilde{J}}^{+}$ & 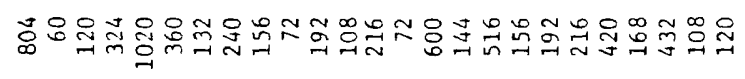 \\
\hline$t$ & 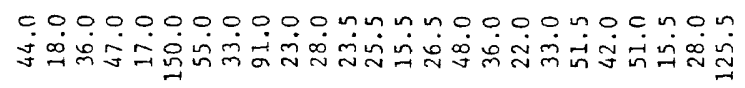 \\
\hline a & 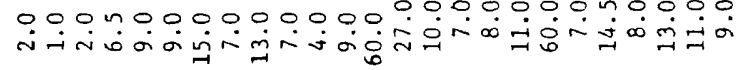 \\
\hline 폼 & 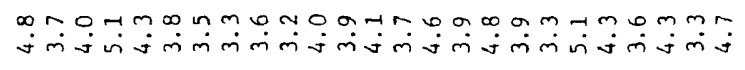 \\
\hline$\stackrel{0}{0}$ & 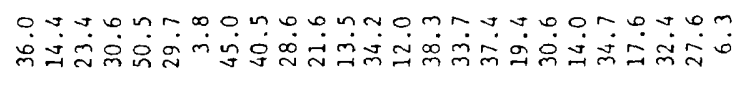 \\
\hline 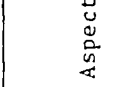 & 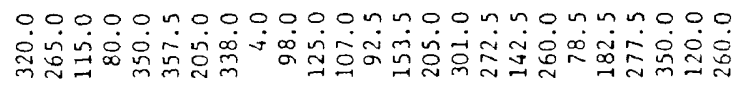 \\
\hline 竞 & 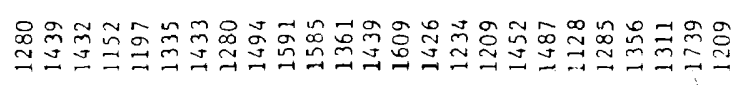 \\
\hline 莺 & $\sigma=$ \\
\hline
\end{tabular}


Table 23. Diversity indices, by stand. Abbreviations of community-type: $S F=$ spruce-fir, $S=$ spruce, $Y B=y e l l o w$ birch, $M M=$ mixed mesophytic, $\mathrm{NH}=$ northern hardwoods, $\mathrm{NRO}=$ northern red oak, $\mathrm{MO}=$ mesophytic-oak, $L E=l o w e r$ el evation. All diversity indices ( $\left.H^{\prime}\right)$ were derived using the Shannon-Weaver formula (see text for explanation).

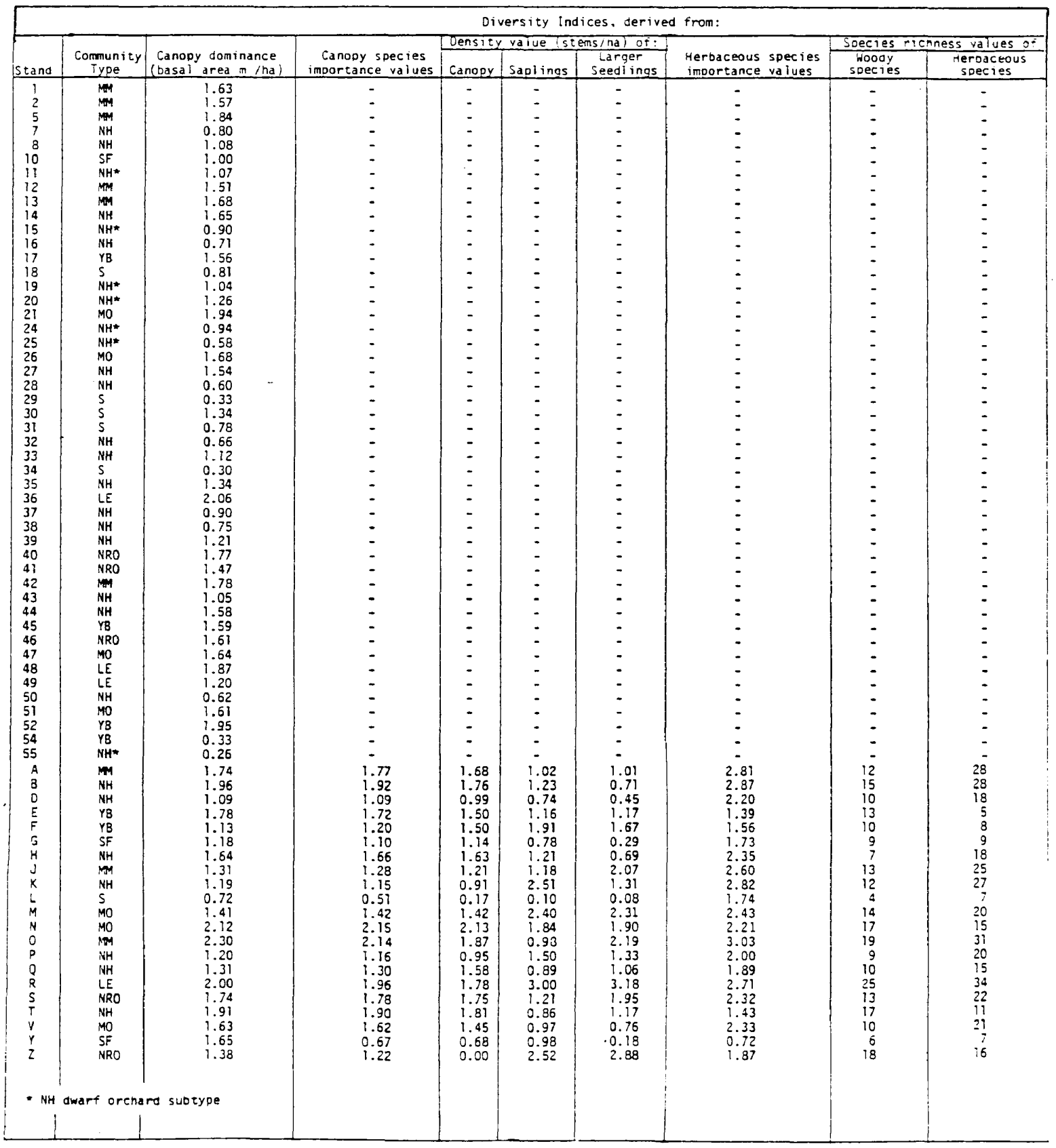




\section{APPENDIX B}

Table 24 shows significant correlations of relative dominance values of canopy species and relative density values of these same species in the understory (saplings, larger seedlings, and small seedlings) with the measured environmental variables. Canopy data was split into hardwood stands above $1150 \mathrm{~m}$ and boreal coniferous forest stands. This table is similar to Table 5 in the text, but differs in that it portrays the remaining minor species.

Table 25 shows the significant correlations among the dominance values of canopy species. Again, data was split into hardwood stands above $1150 \mathrm{~m}$ and those of coniferous forests prior to running the analysis.

Table 26 shows significant correlations between the 25 most common herbaceous species' importance values and the measured environmental parameters, while Table 27 shows the significant correlations among these species. 
Table 24. Significant correlations between canopy species and environmental variables. (Refer to Table 5 for explanation of abbreviations.)

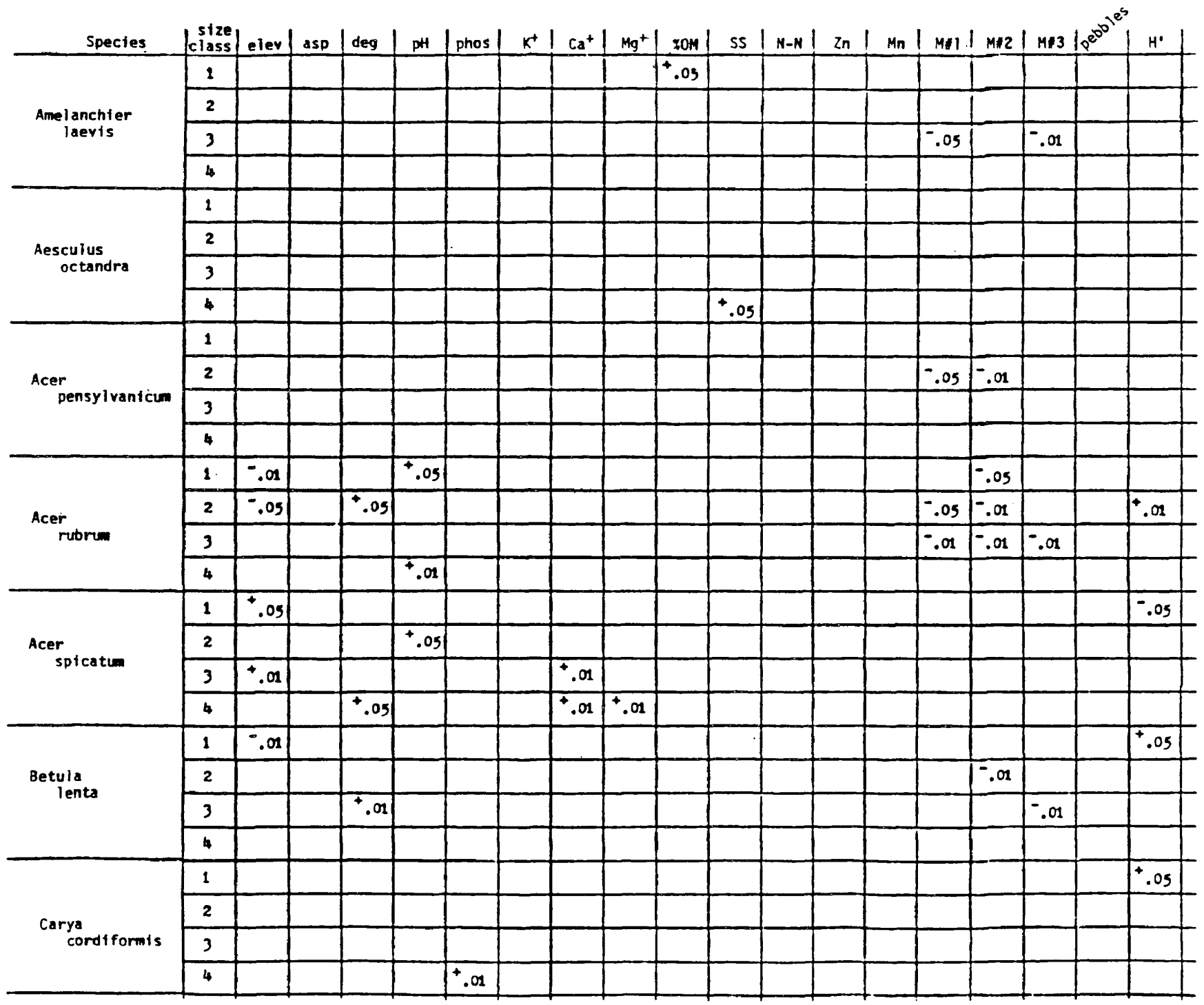

Continued 
Table 24 Continued

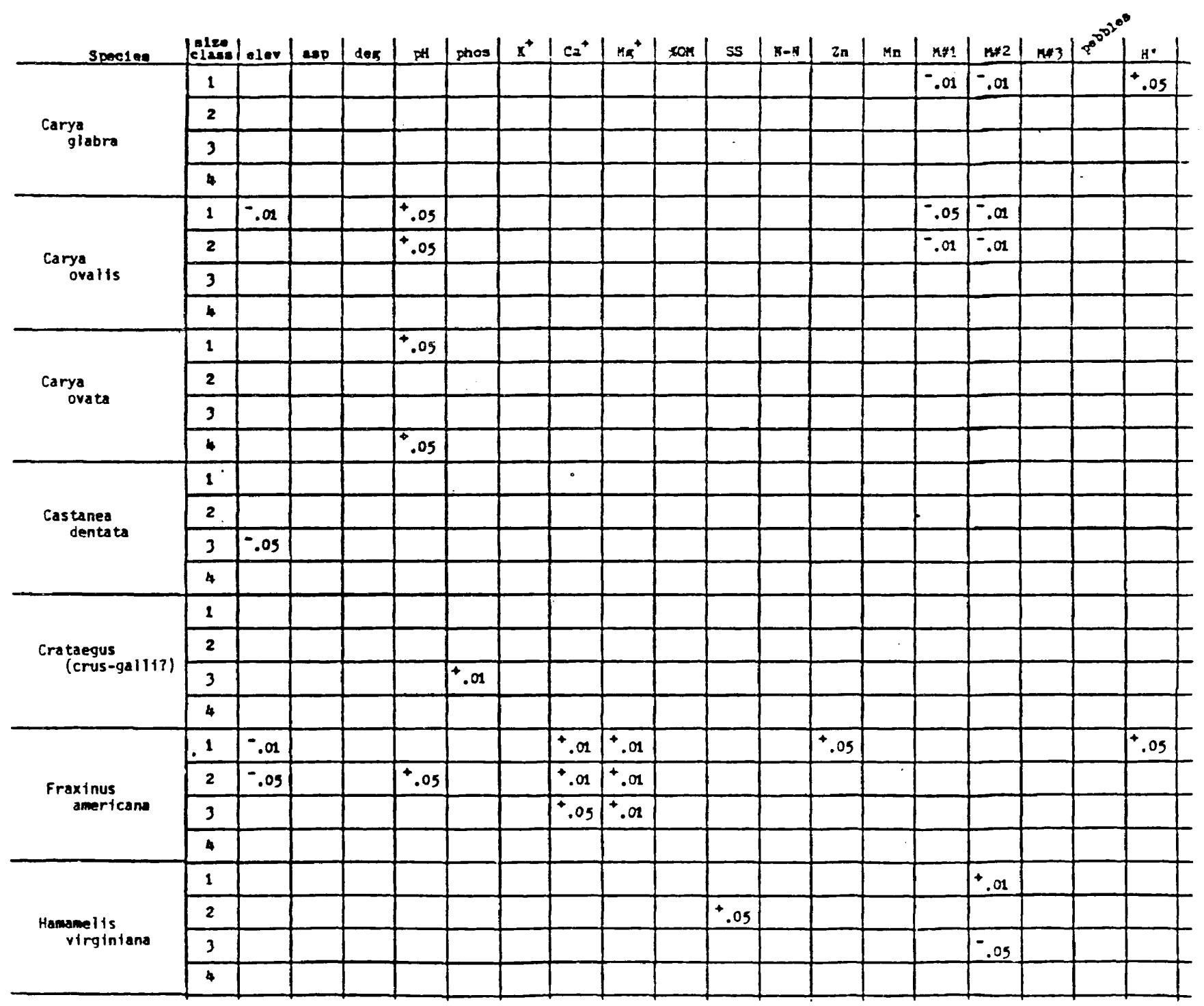


Table 24 Continued

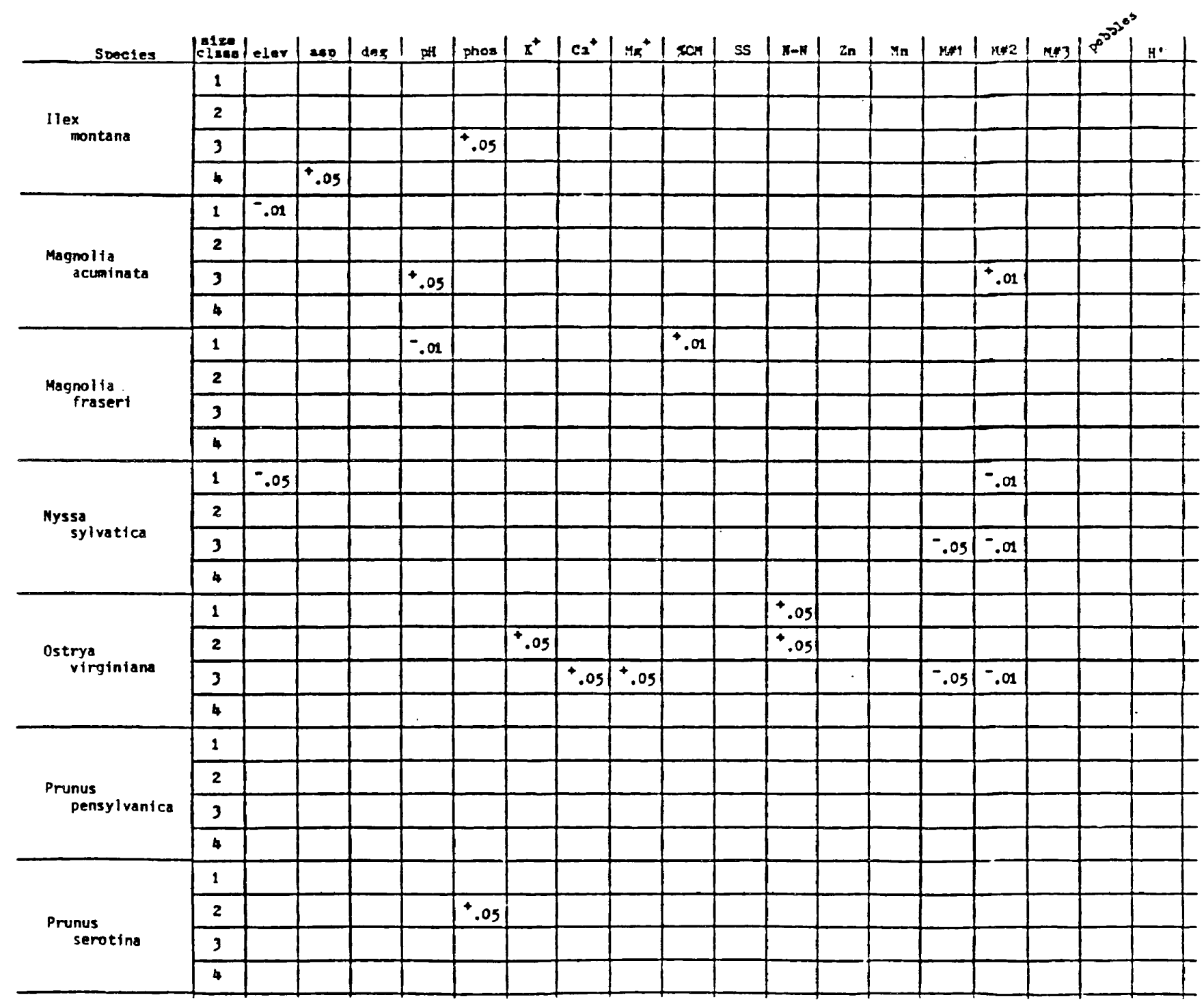


Table 24 Continued

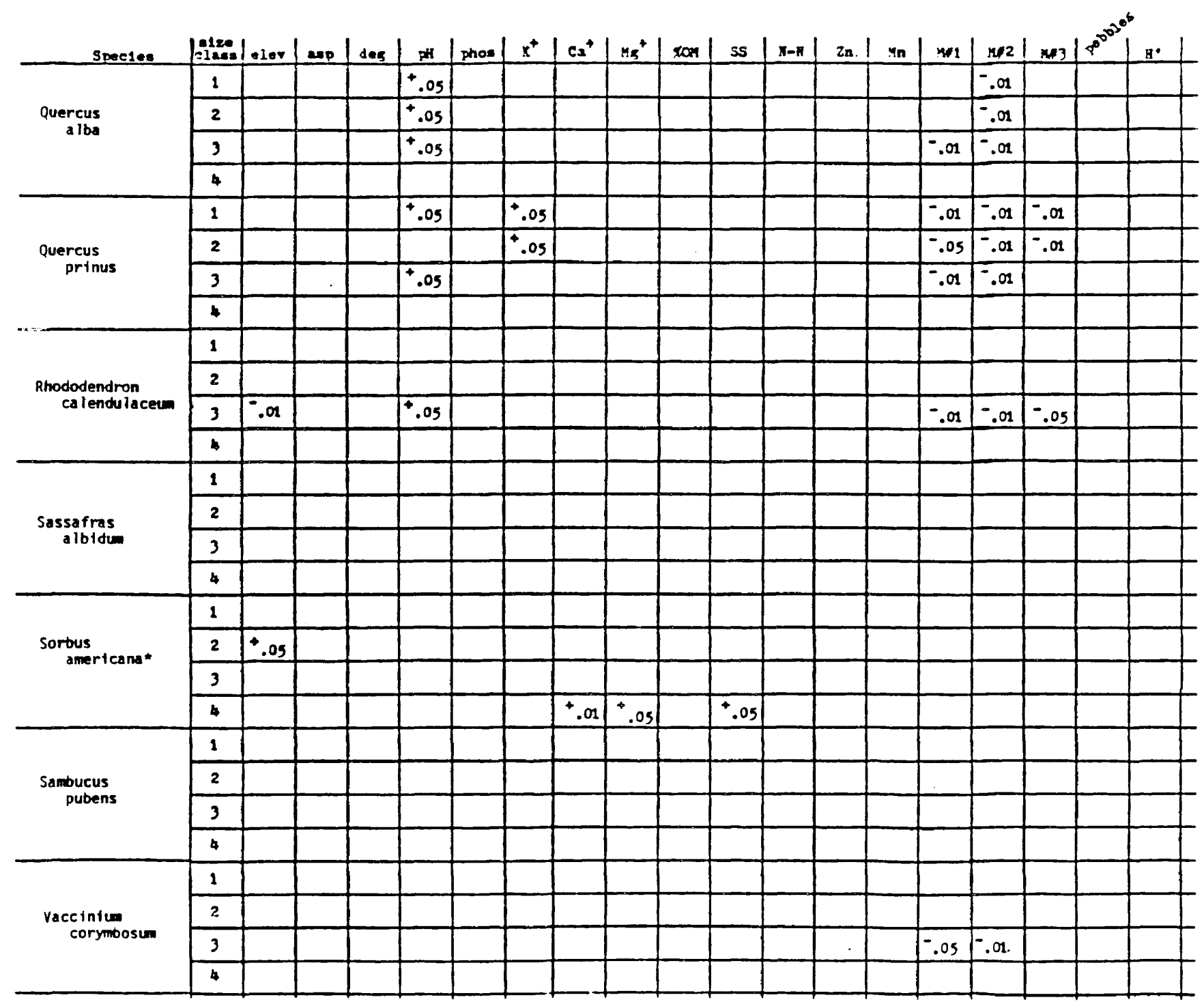




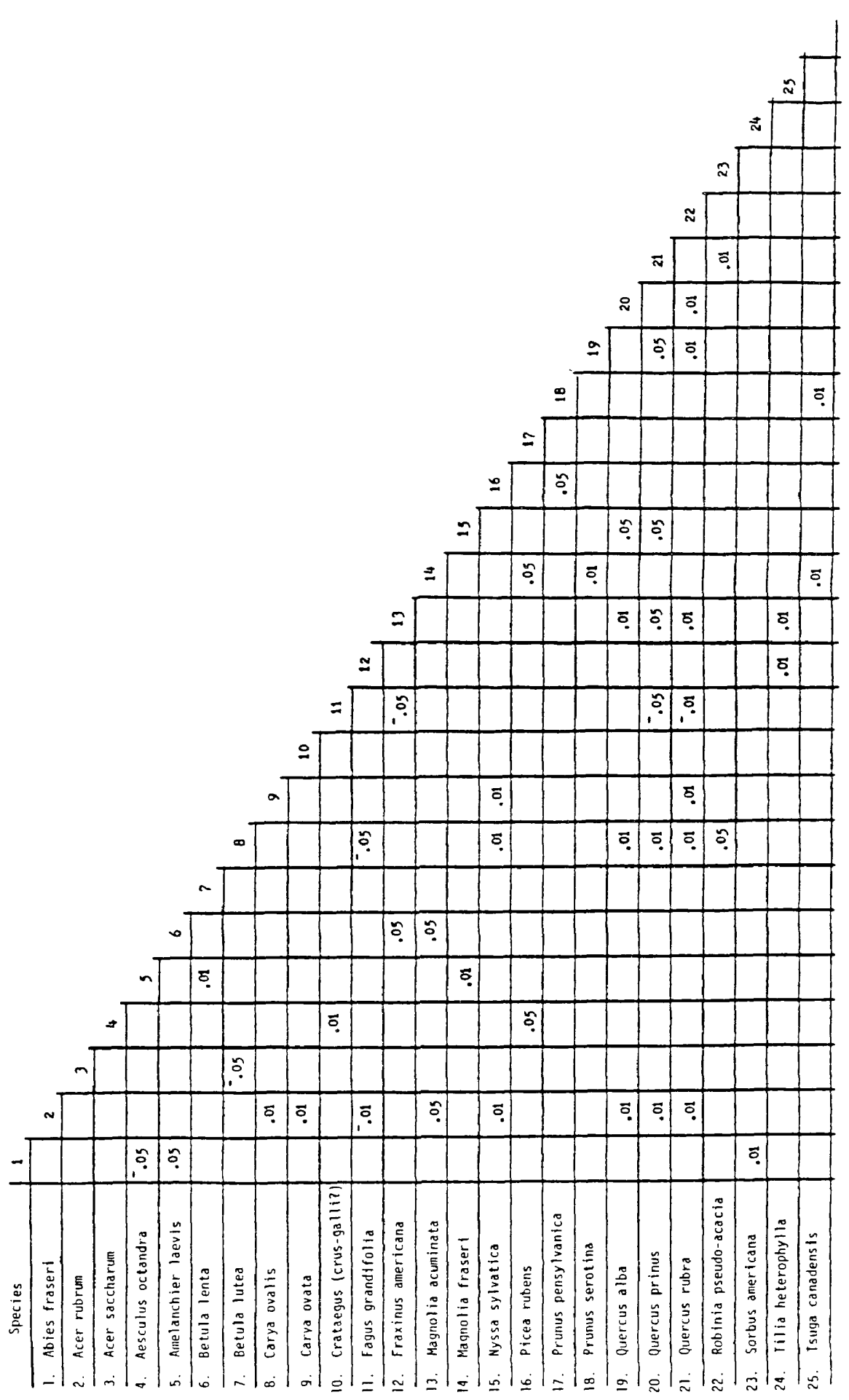

$\frac{0}{\circ}$ 


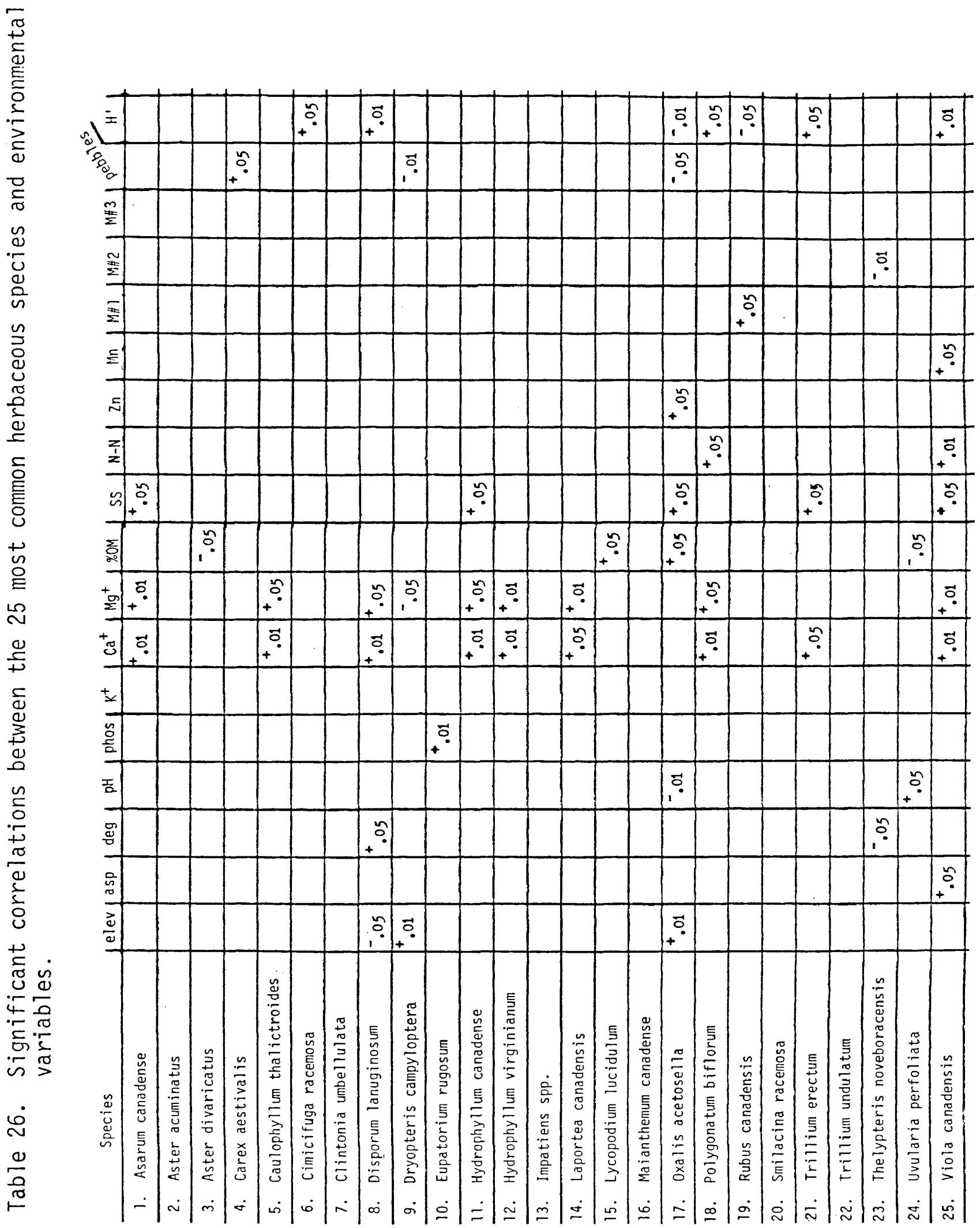


143.
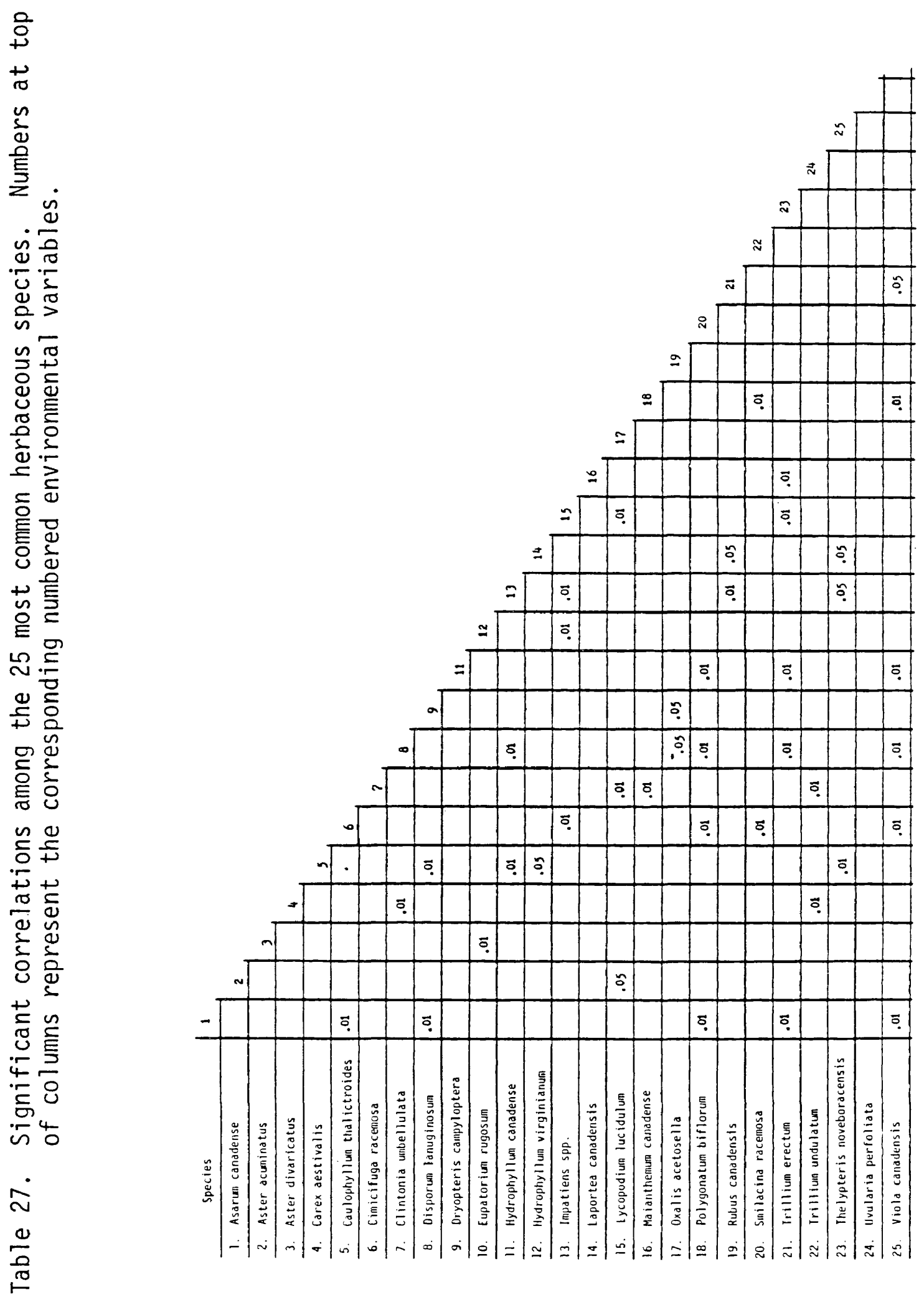


\section{LITERATURE CITED}

Braun, E. L. 1950. Deciduous forests of eastern North America. New York: Hafner, 596 pp.

Bray, J. R. and J. T. Curtis. 1957. Ordination of the upland forest communities of southern Wisconsin. Ecol. Monog. 27: 325-349.

Brown, D. M. 1941. The vegetation of Roan Mountain: a phytosociological and successional study. Ecol. Monog. 11: 61-97.

Cain, S. A. 1935. Ecological studies of the vegetation of the Great Smoky Mountains II. The quadrat method applied to sampling spruce and spruce-fir forest types. Am. Midl. Nat. 16: 566-584.

Camp, W. H. 1951. A biogeographic and paragenetic analysis of the American beech (Fagus). Am. Philos. Soc. Yearbook 50: 166-169.

Curtis, J. T. and R. P. McIntosh. 1951. An upland forest continuum in the prarie-forest border region of Wisconsin. Ecology 32: 476-496.

Daubenmire, R. 1968. Plant communities: a textbook of plant synecology. New York: Harper and Row, 300 pp.

Davis, J. H., Jr. 1930. Vegetation of the Black Mountains of North Carolina: an ecological study. J. Elisha Mitche11 Sci. Soc. 45: 291-318.

Harshberger, J. W. 1981. Phytogeographic survey of North America. New York: Hafner, 809 pp.

Johnson, G. G, and S. Ware. In press. Post-chestnut forest in the central Blue Ridge of Virginia. Castanea.

Levy, G. F. and S. W. Walker. 1971. The combined Bitterlich-rangefindercircular quadrat method in phytosociological studies. The Newsletter 5: $37-39$.

Newcombe, L. N. 1977. Newcombe's wildflower guide. Boston: Little, Brown, and Co., $490 \mathrm{pp}$.

Oosting, H. J. 1941. Plants occurring on calcareous rock outcrops in North Carolina. Torreya 41:76-81.

1956. The study of plant communities. Second ed. San Francisco: W. H. Freeman, $440 \mathrm{pp}$. 
Petrides, G. A. 1959. A field guide to trees and shrubs. Boston: Houghton Mifflin Co., $490 \mathrm{pp}$.

Poole, R. W. 1974. An introduction to quantitative ecology. New York: McGraw-Hil1 Book Co., $532 \mathrm{pp}$.

Radford, A. E., H. E. Ahles, and C. R. Bell. 1968. Manual of the vascular flora of the Carolinas. Chapel Hill, North Carolina: The University of North Carolina Press, $1183 \mathrm{pp}$.

Reed, F. W. 1905. Report on an examination of a forest tract in western North Carolina. U.S. Dept. of Agr. Bur. Forest Bu11. 60: 1-32.

Shields, A. R. 1962. The isolated spruce and spruce-fir forests of southwest Virginia: a biotic study. PhD. Dissertation, Univ. of Tennessee (unpub 7 ished).

Whitfield, L. M. 1978. Mount Rogers National Recreation Area final management plan and environmental impact statement. Washington, D.C.: U.S. Forest Service, USDA.

Whittaker, R. H. 1956. Vegetation of the Great Smoky Mountains, Ecol. Monog. 26: 1-80. 
VITA

RICHARD DAVID RHEINHARDT

Born in Evansville, Indiana on June 11, 1954. Graduated from Evansville Day School in that city in May, 1972. Received a B.B.A. in Management from the College of William and Mary in Virginia in 1976.

Entered the graduate program in biology at the College of William and Mary in 1979. Employed as a graduate teaching assistant $1 / 80$ to $5 / 80$ and $1 / 81$ to $5 / 81$. 